LUCIANE MOTA VIRGILIO

FINANCIAMENTO PARA HABITAÇÕES POPULARES NO BRASIL E NO MÉXICO: UMA ANÁLISE COMPARADA.

São Paulo

2010 


\title{
FINANCIAMENTO PARA HABITAÇÕES POPULARES NO BRASIL E NO MÉXICO: UMA ANÁLISE COMPARADA
}

\author{
Dissertação apresentada à Escola \\ Politécnica da Universidade de \\ São Paulo para obtenção do \\ Título de Mestre em Engenharia Civil \\ Área de Concentração: \\ Engenharia da Construção Civil \\ e Urbana.
}

Orientadora:

Prof ${ }^{a}$. Dra Eliane Monetti

São Paulo 
Este exemplar foi revisado e alterado em relação à versão original, sob responsabilidade única do autor e com a anuência de seu orientador.

São Paulo, de outubro de 2010.

Assinatura do autor

Assinatura do orientador

FICHA CATALOGRÁFICA

Virgilio, Luciane Mota

Financiamento para habitações populares no Brasil e no México: uma análise comparada / L.M. Virgilio. -- ed.rev. -- São Paulo, 2010.

$98 \mathrm{p}$.

Dissertação (Mestrado) - Escola Politécnica da Universidade de São Paulo. Departamento de Engenharia de Construção Civil.

1. Habitação popular 2. Crédito imobiliário 3. Financiamento imobiliário l. Universidade de São Paulo. Escola Politécnica. Departamento de Engenharia de Construção Civil II. t. 
Dedico este trabalho ao Fernando, Iza e Dudu pela alegria diária que trazem a minha vida 


\section{AGRADECIMENTOS}

Inúmeras foram às pessoas que contribuíram e me inspiraram para que conseguisse concluir este trabalho. Porém algumas delas eu não poderia deixar de citar seja pela importância ou pela influência que exercem em minha vida. Iniciaria agradecendo a Deus por tê-las colocado em meu caminho.

Agradeço à orientadora Prof. Dra. Eliane Monetti por além de seu empenho, paciência e contribuições fundamentais para a elaboração deste trabalho ter transmitido o gosto e a importância de uma pesquisa.

Aos professores do GEPE_RES, Dr. João da Rocha Lima, Dr. Claúdio Tavares de Alencar e Dr. Sérgio Alfredo Rosa, pelos inestimáveis conhecimentos passados ao longo do curso.

A todos os meus colegas da Escola Politécnica em especial ao Claudio Gaiarsa, pelo incentivo e ajuda nos momentos difíceis.

Aos parceiros do escritório, principalmente à Mayana pelo apoio e compreensão.

Ao Sr. Celso Petrucci pela disponibilização de dados para a pesquisa e pelo apoio ao longo do trabalho.

Aos meus avós, que bravamente enfrentaram uma vida difícil, mas que com muita luta e coragem em busca de melhores condições de vida iniciaram uma trilha que foi caminhada pelos seus sucessores e que explicam a minha chegada. Aos meus pais pela dedicação dados ao longo de minha existência e principalmente por me deixarem livre para perseguir meus sonhos. Aos meus irmãos por terem feito parte da minha infância e tê-las tornado ainda mais feliz.

Ao meu marido Fernando pelo apoio incondicional dado durante todos estes anos, pela cumplicidade, pelas críticas construtivas que tanto me ajudaram, pela parceria pessoal e profissional que nos levou a grandes projetos juntos e pelo melhor destes projetos: nossos filhos, Iza e Dudu, razões da minha vida e luta por um mundo melhor.

Enfim a todos que direta ou indiretamente ajudaram e me apoiaram nesta jornada, 


\section{RESUMO}

O déficit habitacional e a falta de acesso ao crédito habitacional, notadamente para a população de baixa renda, são problemas marcantes nos países emergentes, em especial no Brasil. A dificuldade em aliar as condições de pagamento das famílias e o preço da habitação demanda a necessidade de intervenção do Estado por meio de políticas de subsídios.

Experiências em outras nações emergentes, que poderiam ser adaptadas à realidade brasileira, indicam que muitos avanços podem ser alcançados nessa área.

Diante desse panorama, o presente trabalho tem por objetivo analisar a evolução do sistema de financiamento habitacional brasileiro, com foco nas políticas públicas implantadas a partir da década de 1990, além de efetuar uma comparação com as soluções encontradas pelo México a partir da década de 2000.

A conclusão do trabalho indica que, para a faixa de renda analisada, de até cinco salários mínimos, o crescimento do crédito habitacional, a recente estabilidade macroeconômica e alterações no quadro institucional brasileiro não foram suficientes para solucionar o acesso da população à moradia. Propõe-se, portanto, destacar quais os principais aspectos que dificultam este acesso e como seria possível alcançar um resultado positivo nesse âmbito.

Palavras Chave: Habitação Popular, crédito imobiliário, financiamento imobiliário 


\begin{abstract}
The housing deficit and the lack of access to credit, notably for the low-income population, are striking problems in emerging economies, especially in Brazil. The difficulty in combining the families' capacity to pay and the price of housing requires the need for intervention by the State through subsidy policies.

Experiences in other emerging economies - that could be adapted to the Brazilian reality indicate that many advances can be achieved in that area.

In face of this, the present study aims at analyzing the evolution of the Brazilian housing finance system, focusing on public policies held since the 1990s, as well as making a comparison to the solutions found by Mexico since the 2000s.

In its conclusion, this study indicates that for the income range we chose to analyze - up to five minimum wages - housing credit growth, the recent macroeconomic stability, and changes in the Brazilian institutional framework were not enough to solve this population's access to housing. It is proposed therefore to highlight what the main issues that hinder this access and how it would be possible to achieve a positive outcome in that respect.
\end{abstract}




\section{SUMÁRIO}

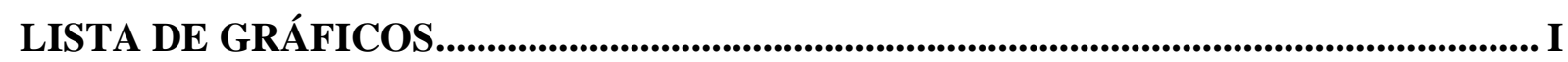

LISTA DE FIGURAS.................................................................................................................II

LISTA DE TABELAS ..................................................................................................... III

LISTA DE ABREVIATURAS E SIGLAS ............................................................................... IV

1 INTRODUÇÃO .........................................................................................1

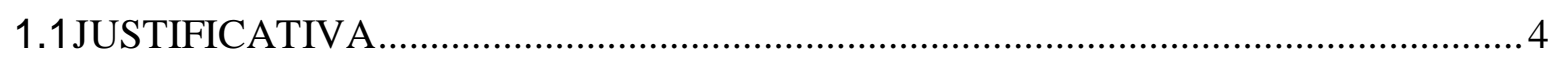

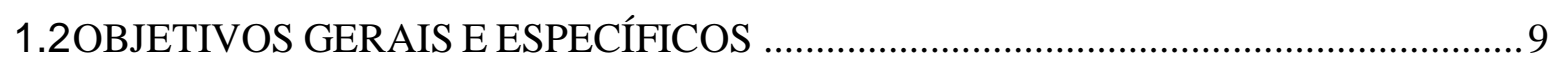

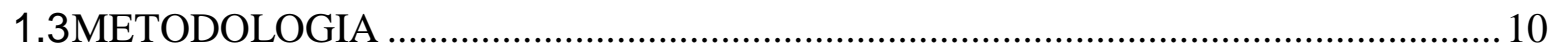

2 HISTÓRIA DO FINANCIAMENTO HABITACIONAL BRASILEIRO APÓS 196412

2.1 SISTEMA FINANCEIRO DA HABITAÇÃO - SFH ………………………………....12

2.1.1 PRINCIPAIS FONTES DE RECURSOS DO SFH ……....................................15

2.2A PRINCIPAL FONTE DE RECURSO DO SFH PARA HABITAÇÕES POPULARES:

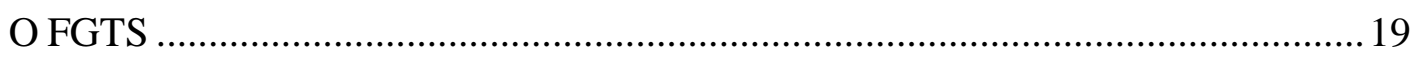

2.2.1 SOBRE A ALOCAÇÃO DOS RECURSOS DO FGTS...........................................23

2.2.2 SOBRE OS FINANCIAMENTOS DOS RECURSOS DO FGTS ………………....27

2.2.3 SOBRE A ARRECADAÇÃO DO FGTS ...........................................................2

2.2.4 PERFIL DOS MUTUÁRIOS QUE RECORREM AO FGTS POR FAIXA DE

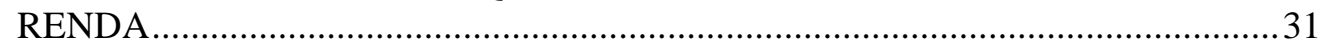

2.2.5 DADOS DO FGTS NO FINANCIAMENTO HABITACIONAL BRASILEIRO ...33

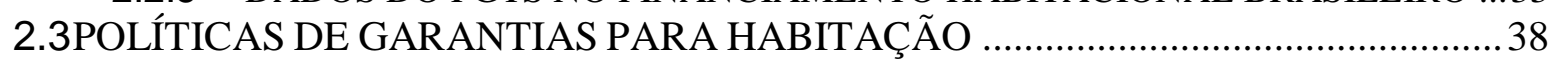

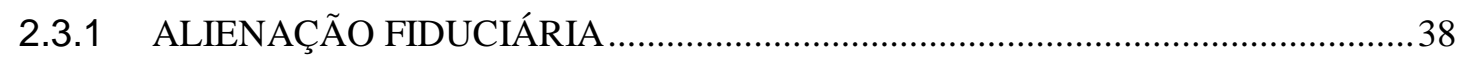

2.3.2 PATRIMÔNIO DE AFETAÇÃO........................................................................40

2.4A QUESTÃO TRIBUTÁRIA DO FINANCIAMENTO À HABITAÇÃO POPULAR .....................41

2.5ANÁLISE DE MECANISMOS DE POLÍTICA DE CRÉDITOS PARA O BRASIL ....42

3 O PROGRAMA MEXICANO. .45

3.1 PRINCÍPIOS E TENDÊNCIAS DO MERCADO HABITACIONAL MEXICANO .....48

3.2A IMPORTÂNCIA DOS ÓRGÃOS PÚBLICOS E DA INICIATIVA PRIVADA .........49 
3.3OS FUNDOS DE GARANTIA NO FINANCIAMENTO HABITACIONAL

MEXICANO .50

3.4A PRINCIPAL FONTE DE RECURSOS PARA HABITAÇÃO POPULAR NO MÉXICO: O INFONAVIT

4 A PERSPECTIVA BRASILEIRA E OS AJUSTES NECESSÁRIOS PARA O

FINANCIAMENTO HABITACIONAL 60

4.1 APLICAÇÃO DE INICIATIVAS MEXICANAS AO BRASIL 60

4.2BARREIRAS AO DESENVOLVIMENTO DO CRÉDITO BRASILEIRO 63

4.2.1 AS SOLUÇÕES URBANAS, O USO E A OCUPAÇÃO DO SOLO MEXICANO E BRASILEIRO 66

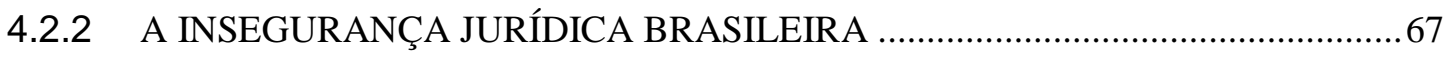

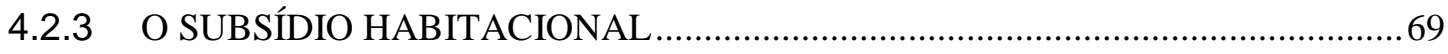

4.2.4 A FALTA DE PERENIDADE NOS PROGRAMAS HABITACIONAIS E NAS

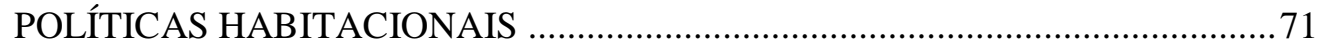

4.2.5 AS PRINCIPAIS DIFERENÇAS E SEMELHANÇAS NOS DOIS SISTEMAS ....72

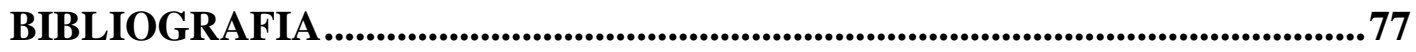




\section{LISTA DE GRÁFICOS}

GRÁFICO 01 - INVESTIMENTOS EM UNIDADES HABITACIONAIS NO PERÍODO DE 2003-2008 3

GRÁFICO 02 - POPULAÇÃO RESIDENTE, POR SITUAÇÃO DO DOMICÍLIO - BRASIL

$-1940 / 2000$ 5

GRÁFICO 03 - DISTRIBUIÇÃO DO DÉFICIT HABITACIONAL URBANO POR REGIÃO 2007 .6

GRÁFICO 04 - DÉFICIT HABITACIONAL URBANO (1), SEGUNDO FAIXAS DE

RENDA MENSAL FAMILIAR (2) BRASIL - 2007. .7

GRÁFICO 05 - A ARRECADAÇÃO DO FGTS - VOLUME EM BILHÕES DE REAIS E

PERCENTUAL DE CRESCIMENTO ANUAL .22

GRÁFICO 06 - UNIDADES FINANCIADAS PELO SFH .23

GRÁFICO 07 - ALOCAÇÃO DE RECURSOS DO FGTS PARA AQUISIÇÃO DE

UNIDADES DISTRIBUÍDA POR FAIXA DE RENDA NO PERÍODO DE 2001 - 200726 GRÁFICO 08 - FINANCIAMENTOS HABITACIONAIS COM RECURSOS DO FGTS,

EXCLUÍDO PROGRAMA DE MATERIAIS DE CONSTRUÇÃO. 28

GRÁFICO 09 - ORÇAMENTO DE ARRECADAÇÃO DO FGTS. 31

GRÁFICO 10 - HABITAÇÃO - PERFIL DAS CONTRATAÇÕES COM PESSOA FÍSICA QUANTIDADE DE CONTRATOS X VALOR CONTRATADO. 31

GRÁFICO 11 - HABITAÇÃO - PERFIL DAS CONTRATAÇÕES COM PESSOA FÍSICA QUANTIDADE DE UNIDADES X VALORES DESEMBOLSADOS ............................ 32

GRÁFICO 12 - HABITAÇÃO - UNIDADES FINANCIADAS POR MEIO DO FGTS ........34

GRÁFICO 13 - HABITAÇÃO - VALORES FINANCIADOS POR MEIO DO FGTS ..........34

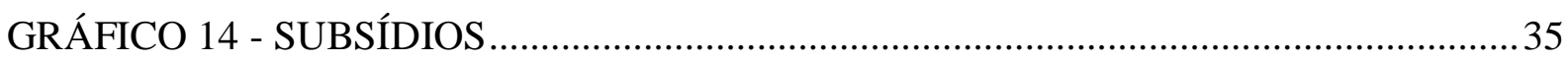

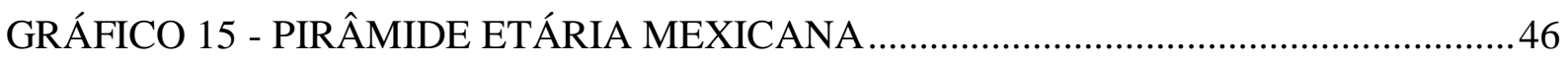

GRÁFICO 16 - PODER DE COMPRA DO SALÁRIO MÍNIMO .......................................47

GRÁFICO 17 - EMISSÃO DE CRÉDITOS MEXICANOS - 2006.......................................58

GRÁFICO 18 - COMPARAÇÃO ENTRE O ESTOQUE DE FINANCIAMENTOS E O

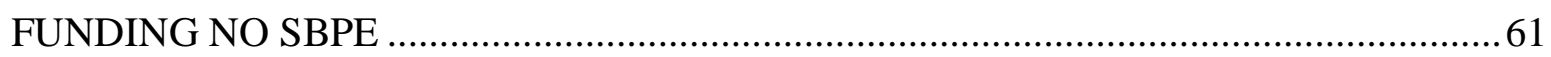




\section{LISTA DE FIGURAS}

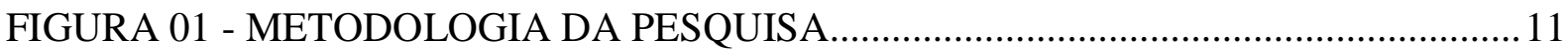

FIGURA 02 - PRINCIPAIS PROGRAMAS FEDERAIS …................................................ 15

FIGURA 03 - AS RESPECTIVAS FONTES DE RECURSOS DOS PROGRAMAS

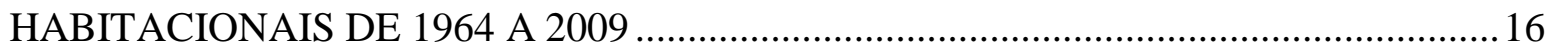

FIGURA 04 - FLUXOGRAMA DO FUNCIONAMENTO DO FGTS ...............................20

FIGURA 05 - FLUXOGRAMA DE FUNCIONAMENTO DA ALIENAÇÃO FIDUCIÁRIA

FIGURA 06 - O MÉXICO E A LOCALIZAÇÃO DE SEUS PRINCIPAIS CENTROS .......45

FIGURA 07 - FLUXOGRAMA DO FUNCIONAMENTO DO FOVISSSTE ........................52

FIGURA 08 - AÇÕES MEXICANAS AO LONGO DOS ÚLTIMOS 40 ANOS ...................54 


\section{LISTA DE TABELAS}

TABELA 01 - ÁREA DE ATUAÇÃO/Nº UNIDADES PROPOSTAS NO PERÍODO 17

TABELA 02 - FONTE DOS RECURSOS DO PROGRAMA, EM BILHÕES DE REAIS ...18

TABELA 03 - RECURSOS DO FGTS ALOCADOS NA ECONOMIA EM 2009 25

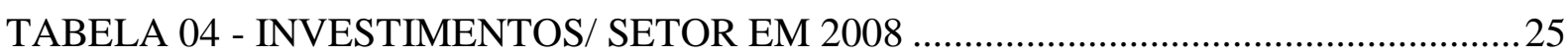

TABELA 05 - EVOLUÇÃO DA ARRECADAÇÃO DO FGTS .........................................29

TABELA 06 - VALORES DAS OPERAÇÕES DE CRÉDITO ...............................................30

TABELA 07 - RETORNO DAS OPERAÇÕES DE CRÉDITO ….........................................30

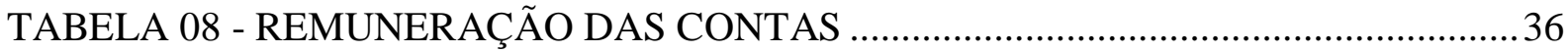

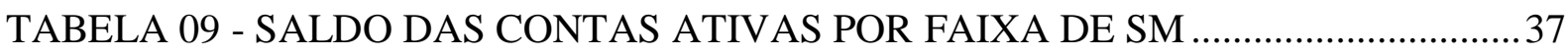

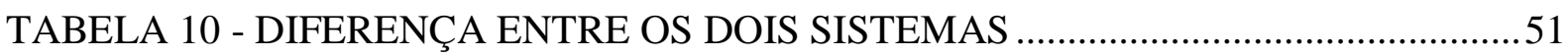

TABELA 11 - OS SEGMENTOS DE MERCADO NA QUAL O MÉXICO ATUA E SUAS

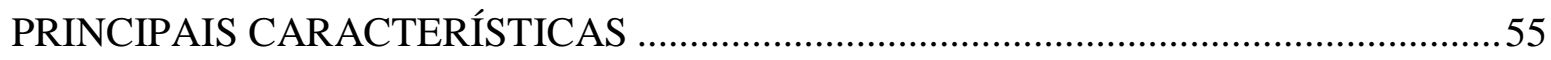

TABELA 12 - REGRAS PARA SE OBTER SUBSÍDIO DO GOVERNOS FEDERAL MEXICANO. .56

TABELA 13 - SIMULAÇÃO DAS CONDIÇÕES PRÉ-ESTABELECIDAS PARA

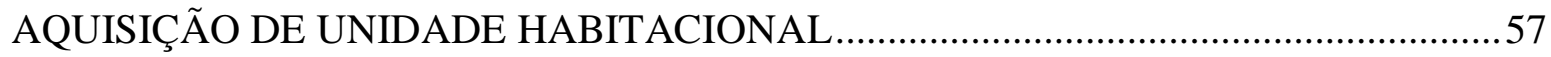

TABELA 14 - OS DOIS SISTEMAS E OS PRINCIPAIS ASPECTOS 73 


\section{LISTA DE ABREVIATURAS E SIGLAS}

APE ASSOCIAÇÃO DE POUPANÇA E EMPRÉSTIMO

APP ÁREA DE PRESERVAÇÃO PERMANENTE

BNH BANCO NACIONAL DA HABITAÇÃO

CCFGTS CONSELHO CURADOR DO FUNDO DE GARANTIA POR TEMPO DE SERVIÇO

CCI CÉDULA DE CRÉDITO IMOBILIÁRIO

CEF CAIXA ECONÔMICA FEDERAL

CRI CERTIFICADO DE RECEBÍVEIS IMOBILIÁRIOS

CVM COMISSÃO DE VALORES IMOBILIÁRIOS

FAR FUNDO DE ARRENDAMENTO RESIDENCIAL

FCVS FUNDO DE COMPENSAÇÃO DE VARIAÇÃO SALARIAL

FDS FUNDO DE DESENVOLVIMENTO SOCIAL

FGTS FUNDO DE GARANTIA POR TEMPO DE SERVIÇO

FII-FGTS FUNDO DE INVESTIMENTO IMOBILIÁRIO DO FUNDO DE GARANTIA POR TEMPO DE SERVIÇO

FIDCS FUNDO DE INVESTIMENTO EM DIREITOS CREDITÓRIOS E DEBÊNTURES

FNHIS FUNDO NACIONAL DE HABITAÇÃO DE INTERESSE SOCIAL FOVI FUNDO DE OPERAÇÃO E FINANCIAMENTO BANCÁRIO Á MORADIA FOVISSSTE FUNDO DE MORADIA DOS TRABALHADORES DO SETOR PÚBLICO MEXICANO

HIS HABITAÇÃO DE INTERESSE SOCIAL

INFONAVIT - FUNDO NACIONAL DA MORADIA PARA OS TRABALHADORES

LCI IETRA DE CRÉDITO IMOBILIÁRIO

OGU ORÇAMENTO GERAL DA UNIÃO

PAR PLANO DE ARRENDAMENTO RESIDENCIAL

PES PLANO DE EQUIVALÊNCIA SALARIAL

PIB PRODUTO INTERNO BRUTO

PSH PROGRAMA SUBSÍDIO A HABITAÇÃO 
SISTEMA BRASILEIRO DE POUPANÇA E EMPRÉSTIMO

SFH SISTEMA FINANCEIRO DA HABITAÇÃO

SFI SISTEMA DE FINANCIAMENTO IMOBILIÁRIO

SHF SISTEMA HIPOTECÁRIO FEDERAL

$\mathrm{SNH}$ SECRETARIA NACIONAL DA HABITAÇÃO

SNHIS SISTEMA NACIONAL DE HABITAÇÃO DE INTERESSE SOCIAL 


\section{INTRODUÇÃO}

A aquisição da casa própria é uma meta para a maioria das famílias brasileiras, está inserida em sua cultura, provavelmente em razão do histórico econômico que o país atravessou até meados da década de 1990, com períodos de elevados índices inflacionários e juros altos, além do desemprego, gerando insegurança. Pode-se dizer que o imóvel próprio trazia, e ainda traz, principalmente para a população de baixa renda, a sensação de segurança, em especial em caso de desemprego.

A essência e importância desse bem, somadas ao peso dos aluguéis no orçamento familiar justificam a pertinência de se refletir sobre financiamento habitacional. A impossibilidade de obtê-lo tem levado as famílias a ocuparem espaços inadequados, impróprios ou ainda não permitidos por lei, gerando, na maioria das vezes, ocupações irregulares e causando danos ao meio ambiente (RODRIGUES, 2009).

Essa situação afeta, principalmente, comunidades de baixa renda, notadamente aquelas com renda inferior a cinco salários mínimos, localizadas nos centros urbanos e regiões metropolitanas do Brasil. As principais causas são: insuficiente renda da população para os gastos com aquisição e manutenção de uma unidade habitacional; processo de urbanização acelerado sem oferta equivalente de espaços adequados (o que acaba elevando os custos do solo urbano); crescimento vegetativo natural da população e, principalmente, falta de políticas públicas consistentes e sustentáveis, o que impossibilita o planejamento de longo prazo por parte de gestores públicos e privados (ABIKO, 1995).

O fato de o elevado custo da moradia ultrapassar a capacidade de pagamento da população pobre, bem como a ausência de um mercado de financiamento de longo prazo adequado justificam a interferência do governo no mercado habitacional, o que pode ocorrer de duas formas: direta, por meio de provisão de moradia destinada à população de baixa renda, ou da disponibilização de fundos públicos para o setor habitacional; indireta, mediante legislação incidente no mercado financeiro, uso do solo e padrões construtivos (MORAIS, 2002).

Nesta perspectiva, é importante estabelecer uma diferenciação entre os clientes da sociedade, ou seja, setores da população que não têm possibilidade de acesso ao sistema 
financeiro e que necessitam da intervenção do Estado, e os clientes bancários, ou seja, setores da população com capacidade de pagamento dos créditos (VASCONCELOS,1996).

Entendida não como um produto, mas sim como um processo que envolve determinantes políticos, econômicos, sociais, jurídicos, ecológicos e tecnológicos, a habitação popular é, justamente, uma solução de moradia voltada à população de baixa renda. Porém, para que cumpra suas funções, é necessário que, além de conter um espaço confortável, seguro e salubre, se integre de forma adequada ao ambiente que a cerca. Ou seja, o conceito de habitação não se restringe, apenas, à unidade habitacional, envolvendo necessariamente o seu entorno, como estrutura física, situação do terreno, infraestrutura (redes de distribuição de água, coleta de esgoto, energia elétrica, sistema viário, etc..), serviços, acessibilidade, localização e equipamentos sociais (edifícios voltados à educação, lazer, etc...) (ABIKO, 1995).

Desde 2004, observa-se um aquecimento no setor habitacional, porém o mesmo não ocorreu em relação à atuação das empresas incorporadoras/construtoras no segmento de habitações populares no Brasil, não conseguindo atingir os clientes da sociedade. Assim, a maior parte dos recursos empregados no financiamento dessas unidades habitacionais foi direcionada a famílias de renda média superior a dez salários mínimos, deixando a população em que se concentra o déficit sem acesso à moradia adequada.

A análise do financiamento à habitação popular no Brasil, objetivo deste trabalho, envolve considerar diversas fontes de recursos públicos, que fazem parte do Sistema Financeiro da Habitação (SFH), sendo a principal delas o Fundo de Garantia por Tempo de Serviço (FGTS), e também o Sistema Brasileiro de Poupança e Empréstimo (SBPE). A ideia é apresentar os valores investidos em habitação popular no Brasil no período de 2003 a 2008, para, posteriormente, identificar a dependência dessas fontes para o setor habitacional, principalmente o popular.

Outras fontes foram também utilizadas na análise:

$>$ Recurso do Orçamento Geral da União (OGU), concedido a fundo perdido, ou seja, não precisa ser ressarcido ao sistema;

> Fundo de Arrendamento Residencial (FAR), criado para financiar o Plano de Arrendamento Residencial (PAR);

Fundo de Desenvolvimento Social (FDS), com recursos destinados ao atendimento do Programa de Crédito Solidário, objetivando o financiamento à produção e à comercialização; 
Fundo Nacional de Habitação de Interesse Social (FNHIS), destinado ao Sistema Nacional de Habitação de Interesse Social (SNHIS), sistema que objetiva integrar todos os programas e projetos voltados à Habitação de Interesse Social (HIS).

Os dados do gráfico 01 foram obtidos a partir de pesquisa efetuada no banco de dados da Secretaria Nacional da Habitação - SNH nas fontes de recursos acima descritas, no período de 2003 a 2008.

\section{GRÁFICO 01 - INVESTIMENTOS EM UNIDADES HABITACIONAIS NO PERÍODO DE} 2003-2008

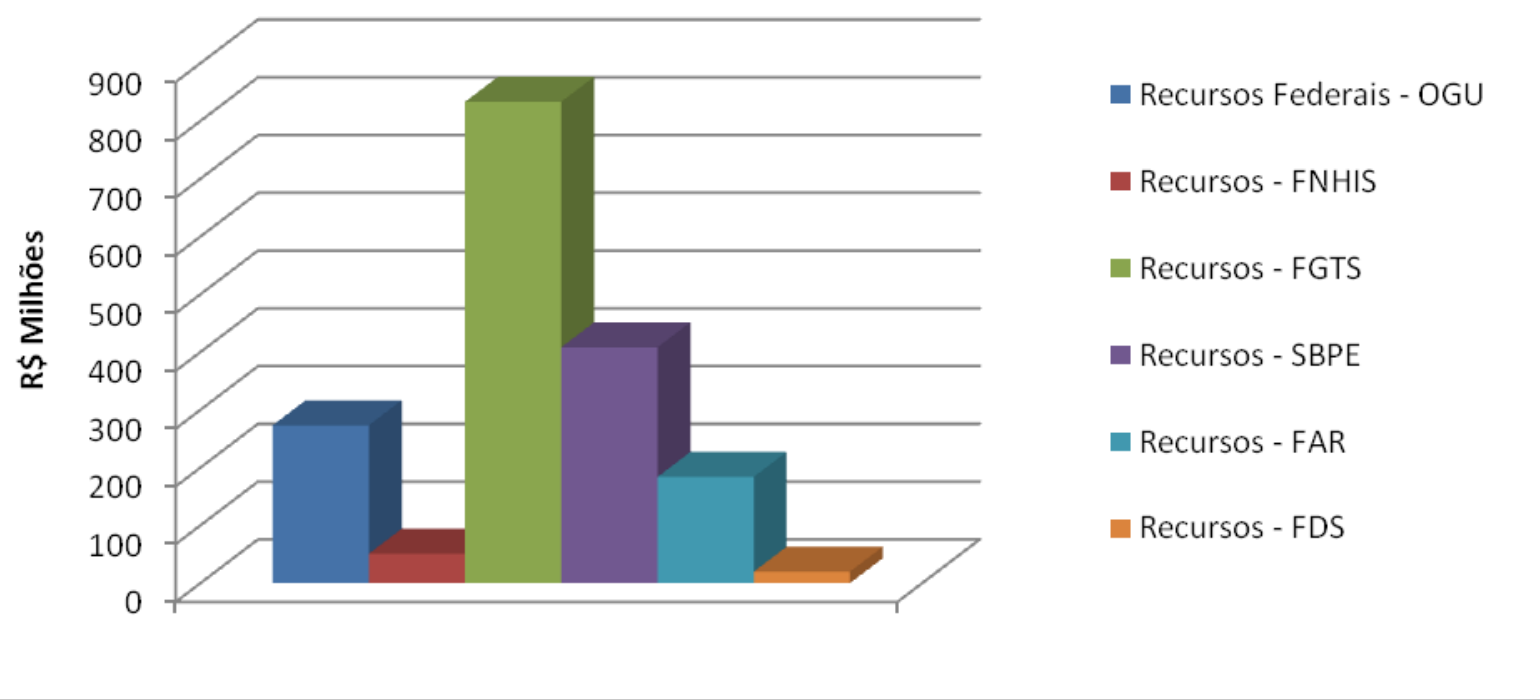

Fonte: Banco de dados da Secretaria Nacional da Habitação, 2008.

A retomada do crescimento econômico brasileiro, em especial nos últimos cinco anos, exigiu uma série de reformas legais e estruturais por parte dos órgãos públicos. As alterações nas legislações, principalmente em relação às garantias, vêm sendo feitas no intuito de criar condições para a atuação da iniciativa privada na recuperação da eficiência e expansão da indústria imobiliária, cuja modernização contribuirá para o aumento dos investimentos nesse setor, do nível de emprego e da qualidade de vida da população. 
Experiências bem sucedidas em outras nações emergentes indicam que muitos avanços podem ser alcançados na área habitacional, desde que uma sólida estrutura institucional e de créditos para as famílias de renda mais baixa embase essas políticas, como ocorreu no México. Este país também convive com um quadro habitacional crítico, porém, como se verá adiante, a criação de políticas sólidas, queda da inflação e dos juros e, em especial, a estabilidade econômica acabaram por alterar o rumo da história mexicana no que se refere à habitação.

\subsection{JUSTIFICATIVA}

No Brasil, a carência habitacional está concentrada em uma faixa de renda específica. O confronto entre a capacidade de pagamento das famílias e os custos com habitação, o processo de urbanização acelerado, em conjunto com a falta de planejamento adequado que leve em consideração as diversas necessidades e condições econômicas da sociedade fazem com que parcelas consideráveis da população tenham cada vez mais dificuldades de acesso à moradia adequada.

Vários são os fatores que contribuíram para a formação do déficit habitacional brasileiro; entre eles, destacam-se a influência do processo de urbanização no Brasil e o crescimento demográfico. A partir da década de 1950, iniciou-se um período em que parte significativa dos brasileiros passou a migrar para os centros urbanos, sobretudo devido ao processo de industrialização que ocorria no país à época. Conforme análise do gráfico 02 , pode-se concluir que, no período de 1950 até 2000, o crescimento natural da população brasileira, associado ao processo de migração intenso geraram a tendência clara de superpopulação nos centros urbanos e consequente demanda por habitações, o que levou a um déficit habitacional nessas regiões.

De acordo com dados do IBGE (2001), a população brasileira entre 1940 e 2000 cresceu de 40 para 140 milhões de habitantes. O percentual da população urbana cresceu de $30 \%$ para mais de $70 \%$ da população brasileira. 


\section{GRÁFICO 02 - POPULAÇÃO RESIDENTE, POR SITUAÇÃO DO DOMICÍLIO -}

BRASIL - 1940/2000

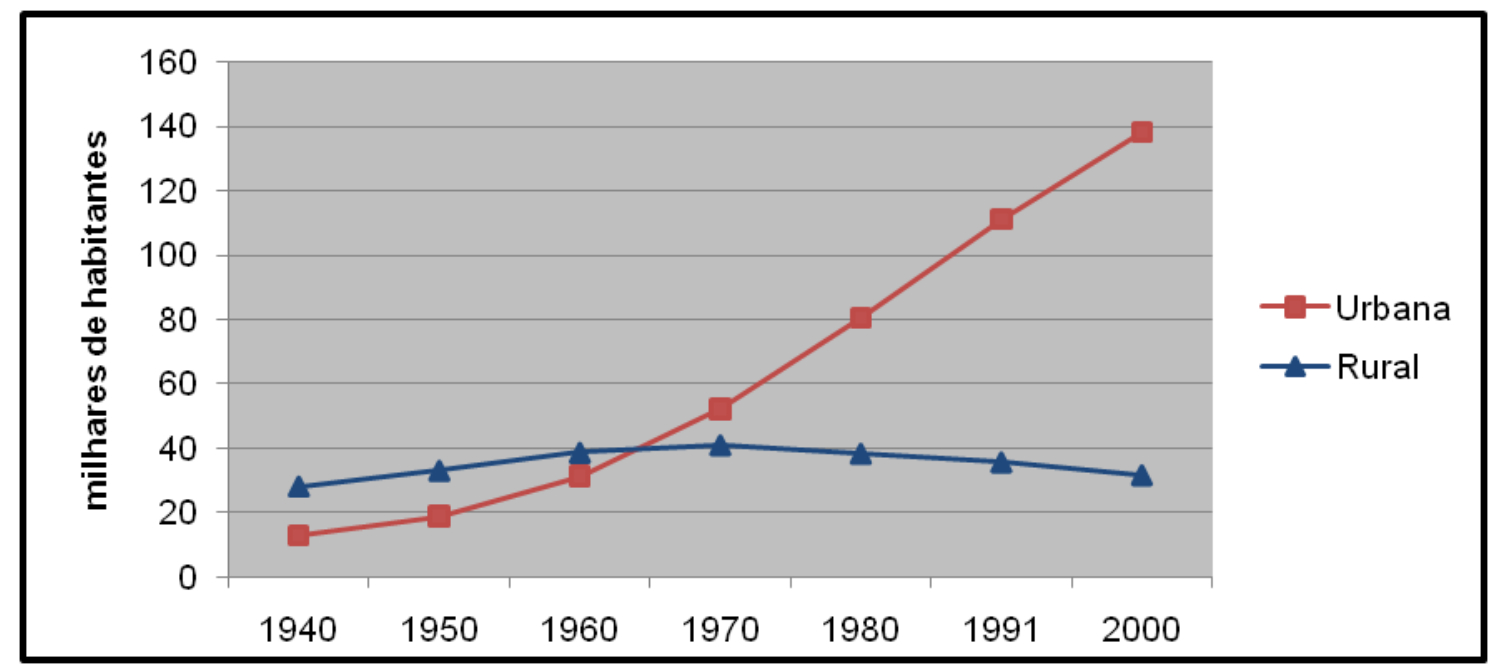

Fonte: IBGE, 2001

Com o crescente processo de urbanização ocorrido no Brasil, os vazios urbanos foram sendo cada vez mais valorizados, impelindo as populações de baixa renda para ocupações irregulares de áreas públicas (principalmente Áreas de Preservação Permanentes - APPs, ao longo de córregos, encostas e demais áreas protegidas), privadas e periferias dos grandes centros, sem planejamento urbano algum. São regiões com pouca infraestrutura e serviços e muito distantes dos centros geradores de emprego, o que leva à necessidade de grandes deslocamentos por parte da população.

De acordo com Abiko (1995), existem vários problemas relativos ao déficit habitacional em áreas urbanas com populações de baixa renda; entre eles, destacam-se:

$\checkmark$ Não regularização da posse;

$\checkmark$ Abastecimento de água precário ou inexistente;

$\checkmark$ Ausência de rede de esgoto e drenagem;

$\checkmark$ Sistema precário e (muitas vezes) clandestino de rede elétrica;

$\checkmark$ Iluminação pública deficiente;

$\checkmark$ Acessos deficientes para locomoção de pessoas, cargas e ao sistema de transportes coletivos;

$\checkmark$ Coleta de lixo deficiente;

$\checkmark$ Habitações precárias. 
Azevedo (2002) ressalta que a questão habitacional deve ser relacionada com outras políticas urbanas, isso porque nem sempre um incremento exclusivamente nos programas habitacionais é a solução mais indicada para melhorar as condições de moradia da população mais pobre. As propostas dos programas para habitação devem considerar políticas urbanas como transporte, energia elétrica, esgotamento sanitário, abastecimento de água, além da habitação propriamente dita.

De acordo com o Ministério das Cidades (2009), na pesquisa intitulada "O déficit habitacional no Brasil 2007", estima-se um total de carências habitacionais em torno de 6 milhões e 273 mil domicílios, sendo 5 milhões e 180 mil, ou 82,60\%, localizados em áreas urbanas.

Ainda na mesma pesquisa, identificou-se que, em termos de distribuição regional, as regiões Nordeste e Sudeste são responsáveis por 71,40\% das carências habitacionais. Porém, o déficit habitacional possui características bastante distintas quando se trata de sua composição: na região Nordeste, grande parte da carência está na área rural; já na região Sudeste, está concentrada nos centros urbanos.

\section{GRÁFICO 03 - DISTRIBUIÇÃO DO DÉFICIT HABITACIONAL URBANO POR REGIÃO 2007}

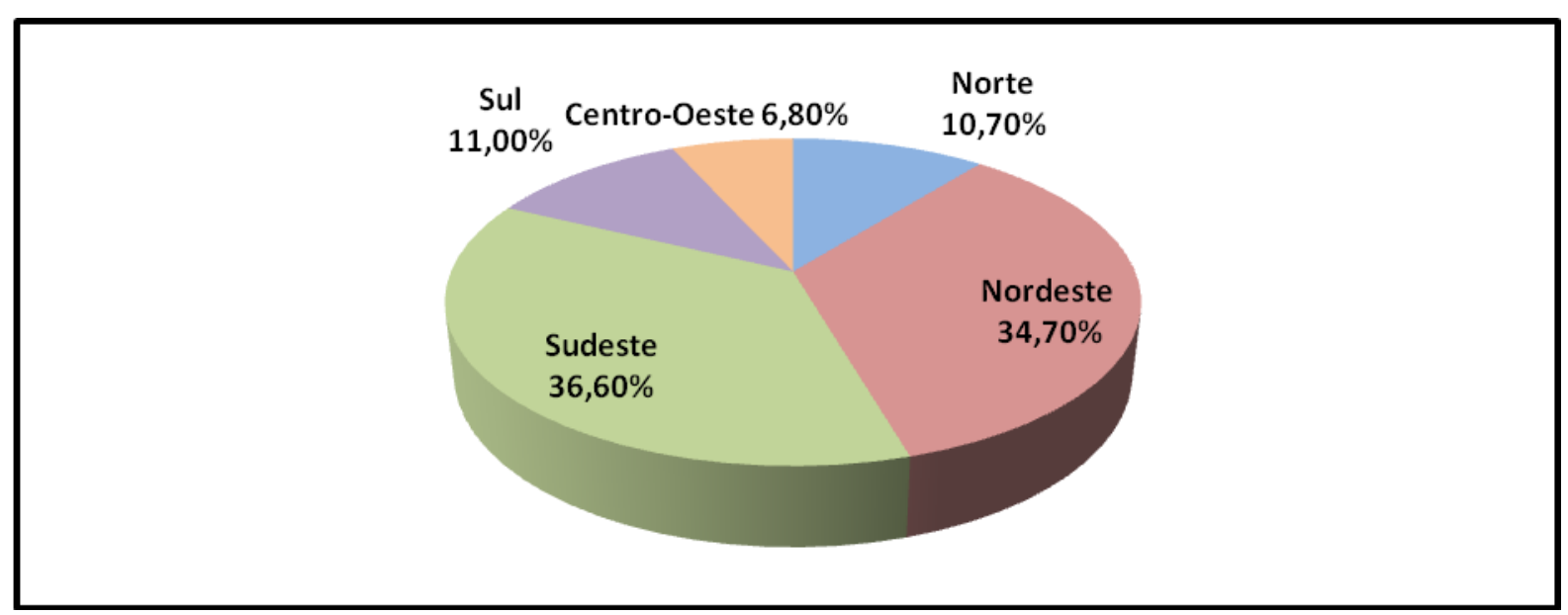

Fonte: Ministério das Cidades (2009).

Analisando o gráfico 04, que descreve o déficit urbano por faixa de renda, constata-se que a totalidade das famílias que necessitam de moradia está na fatia dos que recebem até três salários mínimos: são 89,40\% no Brasil (Ministério das Cidades, 2009). 


\section{GRÁFICO 04 - DÉFICIT HABITACIONAL URBANO (1), SEGUNDO FAIXAS DE RENDA MENSAL FAMILIAR (2) BRASIL - 2007}

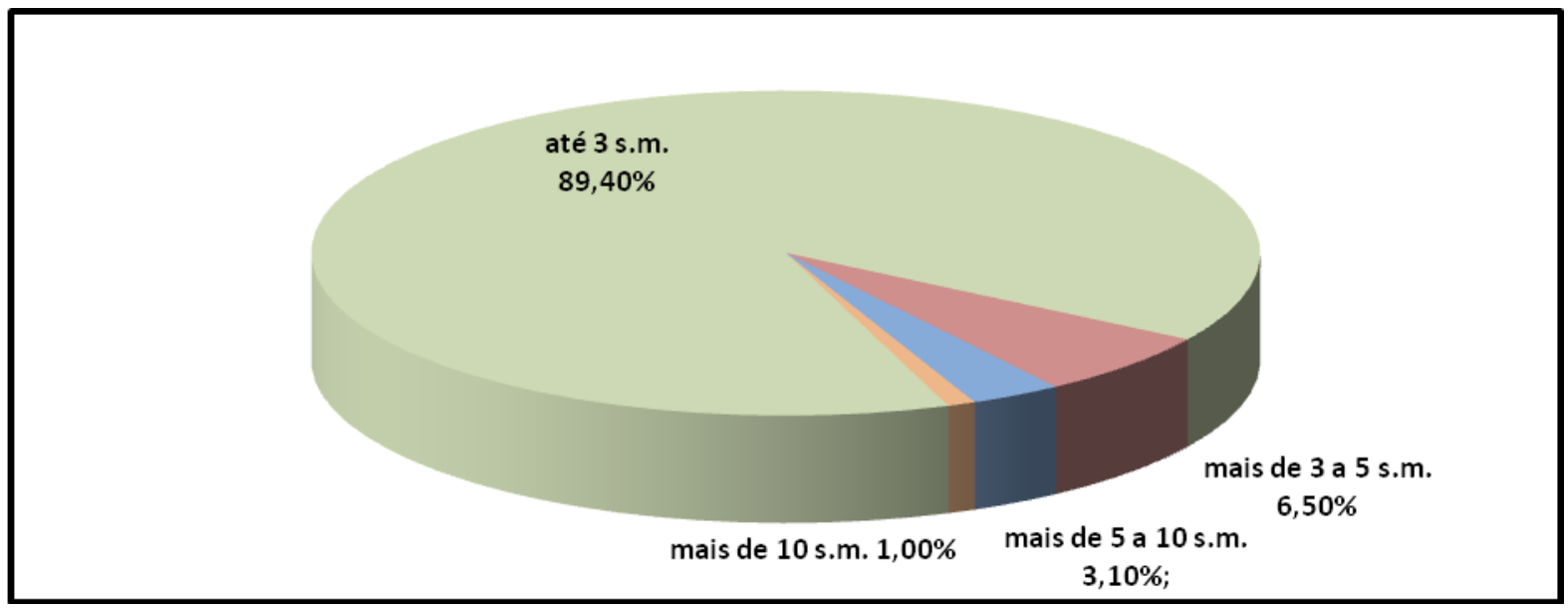

Fonte: Ministério das Cidades (2009).

As estimativas do déficit habitacional brasileiro são discrepantes e variam conforme a metodologia aplicada. Em consequência, a avaliação das políticas públicas voltadas ao combate do problema, como o dimensionamento do mercado por unidades habitacionais no país como um todo e em suas diversas regiões, fica refém dessas estimativas.

Para Vasconcelos e Cândido Júnior (1996), com o crescimento do déficit habitacional, torna-se clara a incapacidade do poder público brasileiro em propor soluções para esse setor. Vários fatores influenciaram nesse insucesso nas últimas décadas, tais como: inconsistência das regras do Sistema Financeiro da Habitação; incidência de compulsórios elevados sobre os depósitos de poupança; atuação do poder judiciário nas reclamações sobre os reajustes das prestações; exigibilidade de aplicações habitacionais a taxas tabeladas; altos índices inflacionários presentes na década de 1980; sucessivas quebras de contrato nos diversos choques econômicos; oscilações acentuadas nos fluxos de depósitos de poupança; altas taxas de juros do mercado e, em especial, falta de segurança das instituições quanto ao quadro institucional e econômico para os anos seguintes.

Atualmente, alguns desses fatores se encontram em condições mais favoráveis, seja por intervenções do poder público, seja pelas perspectivas econômicas e financeiras que o país apresenta. São eles: a inflação, que há alguns anos encontra-se em patamares menores e estáveis, tornando possível a construção de cenários de longo prazo, e as taxas de juros, que, apesar de ainda altas quando comparadas a de outros países, foram reduzidas a níveis 
aceitáveis, além do fato de os agentes econômicos demonstrarem menos receio quanto ao cenário econômico do país.

Existem duas causas principais para a existência das necessidades habitacionais acima descritas:

$1^{\circ}$ Deficiência na produção de moradias;

$2^{\circ}$ Dificuldade de acesso à moradia.

A primeira diz respeito à falta de atendimento à demanda em qualidade, quantidade ou em preço, e a segunda, à dificuldade de acesso pela compra, reforma, aluguel, insuficiência de renda, falta de acesso ao crédito, de subsídios, ou ainda de acesso a financiamentos adequados para a população de baixa renda.

Os financiamentos devem ser divididos em dois grupos distintos: aqueles voltados à produção de unidade habitacional, que financiam os produtores na construção de habitação, e aqueles que visam à comercialização das unidades habitacionais, que financiam o mutuário final na aquisição ou reforma da habitação.

Existem diversas contribuições na literatura nacional e internacional sobre crédito imobiliário. Porém, em vista do quadro habitacional existente no país, alguns fatores precisam ser repensados, como por exemplo: os financiamentos existentes, em especial, o acesso ao crédito habitacional disponibilizado para a população de renda de até cinco salários mínimos.

Vários trabalhos acadêmicos foram e são de grande relevância, no entanto, como o país vem passando por alterações em seu quadro econômico, a bibliografia existente, mesmo a mais recente, aborda aspectos que podem ser considerados desatualizados. Um exemplo é o trabalho de Rossbach, elaborado em 2005, que apresenta dados já superados pela realidade recente do país. Já o estudo de Rodrigues (2009) faz um retrospecto do crédito habitacional do Brasil e em outros países, porém não apresenta dados qualitativos sobre a alocação de recursos desses países, não oferecendo a possibilidade de análises comparativas.

Face à complexidade e importância do tema em termos de implementação de políticas públicas adequadas, principalmente à luz da dificuldade de acesso da população de baixa renda ao crédito imobiliário, considera-se necessário analisar o histórico brasileiro em relação aos sistemas financeiros voltados ao setor habitacional, com a finalidade de identificar seus possíveis problemas. Paralelamente a isso, também é aqui analisado o sistema de crédito no México, tendo em vista o crescimento de concessões a partir de 2002.

Assim, o sistema financeiro de ambos os países são aqui investigados, no sentido de se identificar os aspectos que propiciaram ao México um crescimento significativo na concessão 
de crédito habitacional e quais vêm impedindo o Brasil de alcançar um resultado positivo nesse âmbito.

A atuação objetiva do governo mexicano, no sentido de dar sustentabilidade e segurança ao sistema de crédito, além da perenidade dos programas e da sensibilidade para implementar as necessárias correções tornaram as políticas públicas voltadas ao setor habitacional um instrumento eficiente, seja pela quantidade de financiamentos concedidos para a população de baixa renda, seja pelo número surpreendente de unidades produzidas. Essas ações serviram de inspiração para a elaboração desta pesquisa, que busca formas possíveis de aplicá-las à nossa realidade, de modo a permitir acesso à habitação por parte população brasileira de baixa renda.

Analisando brevemente o histórico do sistema de financiamento brasileiro à luz da literatura existente, além de modelos já adotados pelo México, e também nos EUA e Chile, foi possível obter dados e informações que contribuíram para o melhor entendimento dos problemas brasileiros.

\subsection{OBJETIVOS GERAIS E ESPECÍFICOS}

Brasil e México possuem características muito semelhantes, tanto culturais como econômicas.

Assim como o Brasil, o México também experimentou perdas de bancos na década de 1970, bem como períodos de alta inflação na década de 1980; porém, mudanças estruturais em sua política habitacional a partir de 2000 fizeram com que os mexicanos pudessem vivenciar um número crescente de concessão de crédito imobiliário voltado para baixa renda, em contraste com o Brasil. Cabe avaliar como o México vem solucionando o problema em relação à população de baixa renda e o que falta nas políticas públicas brasileiras e na estrutura de seu mercado imobiliário que impossibilita um avanço significativo do setor.

Diante desse cenário, o objetivo deste estudo é analisar a possibilidade de aplicação das soluções mexicanas ao sistema de financiamento brasileiro, identificando os princípios que o regem, bem como a estruturação de seus mercados e considerando a limitação de renda do público alvo. 


\subsection{METODOLOGIA}

Para a elaboração desta pesquisa, foi realizada inicialmente uma discussão dos conceitos relacionados à habitação, não somente da unidade habitacional como também das necessidades que envolvem o seu entorno, especialmente no que se refere à infraestrutura. Foram analisadas as características do crescimento habitacional brasileiro ao longo dos anos, até chegar ao déficit existente na atualidade.

Foi também realizada uma revisão bibliográfica do sistema habitacional brasileiro desde a implantação do sistema financeiro da habitação em 1964 até o último programa, que data de 2009, enfatizando-se as fontes de recursos utilizadas para posterior comparação com o cenário mexicano.

Foram pesquisadas publicações nacionais e internacionais, como artigos, livros, revistas especializadas, textos disponíveis em Internet, que trazem dados relativos aos tipos de financiamentos existentes tanto no México quanto no Brasil, tratando do funcionamento de seus mercados, das fontes de recursos utilizadas, prazos e subsídios ofertados, destacando as principais características que interferem no acesso da população de baixa renda à habitação.

O trabalho se desenvolveu em quatros etapas, conforme a figura 1. Na primeira foram levantados dados que permitiram agregar o conhecimento prévio dos termos e conceitos a respeito do tema a ser tratado no ambiente da pesquisa. Foram então contemplados os conceitos relativos à habitação popular e levantados aspectos quantitativos e qualitativos do processo de urbanização e déficit habitacional brasileiro.

$\mathrm{Na}$ segunda etapa foi feito um levantamento histórico dos sistemas de financiamento habitacionais do Brasil, destacando os principais programas existentes, em especial a fonte de recurso para habitação popular, qual seja, o FGTS, no intuito de avaliar as soluções adotadas, com ênfase nos procedimentos utilizados para captação e alocação desse recurso.

$\mathrm{Na}$ terceira etapa foram observadas as soluções mexicanas, sendo identificados os desajustes entre a capacidade de pagamento da população de baixa renda e o acesso ao crédito habitacional e quais os fatores que os provocam. Analisou-se a estrutura do mercado financeiro voltada ao setor habitacional mexicano e as soluções urbanas aplicadas, avaliando os impactos dessa ocupação no espaço urbano.

$\mathrm{Na}$ quarta etapa do trabalho foram comparados os dados obtidos nos dois sistemas e propostos ajustes para o Brasil, com sugestões de adequações dos créditos oferecidos, 
considerando as políticas de subsídios existentes de acordo com as necessidades e limitações da população de faixa de renda de até cinco salários mínimos.

O intuito principal da pesquisa foi efetuar, por meio de um levantamento de informações e experiências ocorridas no sistema de financiamento brasileiro e mexicano, uma base de conhecimentos que poderá subsidiar futuras propostas de financiamentos no Brasil.

FIGURA 01 - METODOLOGIA DA PESQUISA

1 ㅡA EA

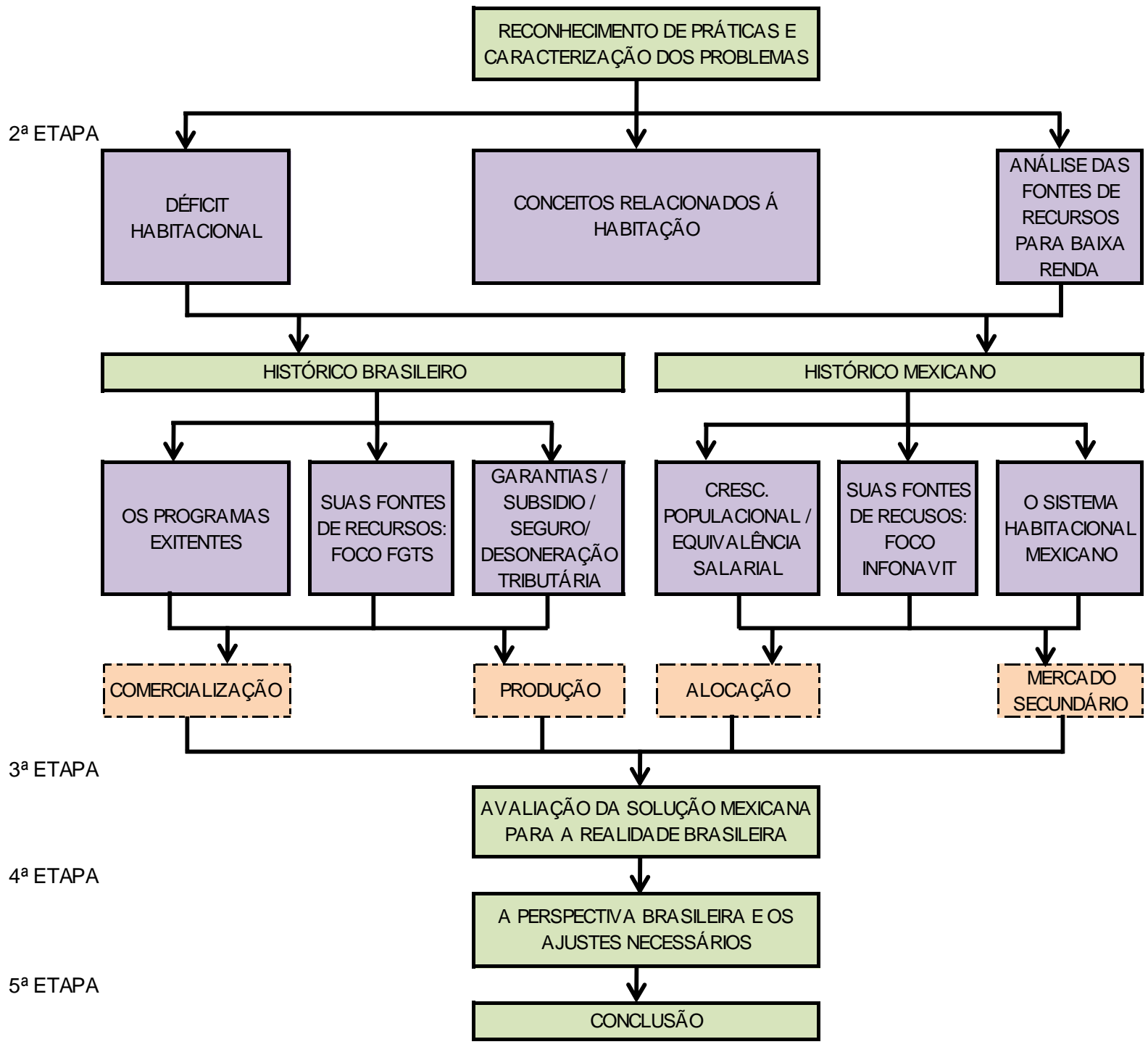

Fonte: Elaborado pela autora. 


\section{HISTÓRIA DO FINANCIAMENTO HABITACIONAL BRASILEIRO APÓS 1964}

O objetivo deste capítulo é descrever o histórico dos principais programas de financiamentos habitacionais brasileiros, desde a criação do Sistema Financeiro da Habitação (SFH) até o mais recente, denominado "Minha Casa, Minha Vida". São analisados os prazos para financiamentos, concessão de créditos à população de baixa renda e, principalmente, suas fontes de recursos, reconhecendo, ao final, como ocorre a alocação da principal fonte de recurso do SFH: o Fundo de Garantia por Tempo de Serviço (FGTS). Importante destacar que o capítulo trata somente dos modelos propostos pelo governo federal, tendo em vista que aqueles propostos pelos estados e municípios atendem as particularidades de cada região.

\subsection{SISTEMA FINANCEIRO DA HABITAÇÃO - SFH}

Anteriormente à entrada em funcionamento do $\mathrm{SFH}$, o crescimento da demanda por habitação era enorme, devido à intensificação do processo de urbanização pelo qual o país passava e pelo fato de o investimento nesse setor não ser suficiente para a demanda crescente.

Além do estímulo à indústria da construção por meio da absorção de contingentes significativos de mão-de-obra não especializada, a criação do $\mathrm{SFH}^{1}$ visava aproximar a oferta das necessidades de habitação a um menor custo (KAMPEL e VALLE, 1974).

De acordo com o Banco Central do Brasil (2006), na montagem do SFH, o objetivo principal foi o de subsidiar as famílias de renda mais baixa por meio de um mecanismo que consistia em cobrar taxas de juros diferenciadas e crescentes, de acordo com o valor do financiamento; como resultado, a combinação dessas taxas produziria uma taxa média capaz de remunerar os agentes que atuavam no sistema.

O SFH possuía basicamente duas fontes de recursos:

$\checkmark$ O Sistema Brasileiro de Poupança e Empréstimos (SBPE): com recursos provenientes do conjunto da captação das letras imobiliárias e cadernetas de poupança;

\footnotetext{
${ }^{1}$ Não será aprofundada aqui a análise do SFH, uma vez que essa temática já está bem documentada em diversos estudos, especialmente em Santos (1999) e Vasconcelos; Cândido Júnior (1996); porém, dados os objetivos deste trabalho, uma análise dos programas federais se faz necessária.
} 
$\checkmark$ O Fundo de Garantia por Tempo de Serviço (FGTS), a partir de 1967: com recursos provenientes de contribuições compulsórias dos trabalhadores empregados no setor formal da economia.

O órgão regulador do SFH era o Banco Nacional da Habitação $(\mathrm{BNH})$, responsável pelo gerenciamento do FGTS, pela normatização e fiscalização da aplicação dos recursos das cadernetas de poupança e pela definição das condições de financiamento das moradias para os consumidores finais. As empresas autorizadas a operar dentro do SFH deveriam se submeter às regras do BNH: caixas econômicas, cooperativas habitacionais, institutos de previdência, sociedades de crédito imobiliário e as Associações de Poupança e Empréstimo (APE).

Medeiros (2007) destaca que a arrecadação do FGTS dependia basicamente dos índices de emprego formal e do salário médio, enquanto o SBPE dependia da renda e da taxa real de juros oferecida aos investidores.

Segundo Santos (1999), o bom desempenho do SFH dependeria principalmente de dois fatores:

$\checkmark$ Capacidade de arrecadação do FGTS e do SPBE;

$\checkmark$ Grau de inadimplência dos mutuários, causado, entre outros fatores, pelas quedas salariais que necessariamente diminuíam sua capacidade de pagamento, aumentando a inadimplência e comprometendo o equilíbrio do sistema.

Ainda para o mesmo autor, o objetivo central era a aplicação de um mecanismo de correção monetária sobre saldos devedores, sendo que as prestações dos financiamentos habitacionais viabilizariam tais investimentos de longo prazo, mesmo em uma economia inflacionária.

Os primeiros anos do SFH foram marcados por uma política anti-inflacionária, havendo um descontentamento por parte da população em razão de a correção monetária ser maior do que os reajustes salariais nominais no período, além do fato de as parcelas sofrerem reajustes trimestrais enquanto os salários só eram reajustados anualmente.

Por isso, nessa época houve a introdução do Plano de Equivalência Salarial (PES) e do Fundo de Compensação das Variações Salariais (FCVS). Criados por intermédio da Resolução 25 de 16/06/1967 do conselho do extinto BNH, tinham como finalidade garantir a quitação junto aos agentes financeiros dos saldos devedores remanescentes de contrato de financiamento habitacional, firmado entre os mutuários e o SFH.

O FCVS foi criado com o propósito de liquidar eventuais saldos devedores residuais. No entanto, considerado o nível inflacionário acima dos padrões inicialmente propostos e os 
reajustes não correspondentes à atualização da dívida, o FCVS não mais foi capaz de assumir a diferença dos descasamentos entre a evolução do saldo devedor e reajustes contratuais, incompatíveis com seu patrimônio e seu fluxo de caixa e, como consequência, o acúmulo da dívida ao longo do tempo. É possível afirmar que a aceleração inflacionária que ocorria no país causou o desequilíbrio do fundo.

Para Santos (1999), o objetivo principal do SFH não foi atingido, uma vez que o mesmo não foi capaz de atender à população de baixa renda, visto que somente $33,5 \%$ das unidades habitacionais financiadas foram destinadas a habitações populares.

Também Rossbach destaca (2005, p.104),

Um dos problemas mais graves do SFH decorreu da aceleração inflacionária ocorrida a partir do final da década de 70 com auge nos anos 80. A deterioração dos salários dos mutuários e o descompasso entre os indices de reajustes salariais e das prestações provocou já nos primórdios do SFH elevados índices de inadimplência.

Além da aceleração inflacionária comentada pelo autor, outro fator considerado grave dentro do SFH era a frágil garantia hipotecária ${ }^{2}$ existente, causando receio aos empreendedores e financiadores, uma vez que eles não possuíam garantia jurídica para a retomada do bem.

No ano de 1985, o quadro existente em relação ao SFH apresentava algumas características desfavoráveis: indicadores sociais em queda (emprego e renda, por exemplo), alto nível de inadimplência, baixa liquidez no sistema, movimentos de mutuários organizados nacionalmente e grande expectativa de que as autoridades resolvessem a crise sem penalizar os mutuários (SANTOS, 1999).

O subsídio ofertado contribui com a diminuição da inadimplência, mas aumentou consideravelmente o descasamento entre a evolução do passivo junto aos poupadores do SBPE e FGTS e o ativo (as prestações dos mutuários) do SFH, contribuindo substancialmente com o déficit do FCVS. Cabe ressaltar que este subsídio foi dado a todos os mutuários do sistema que optaram por ele, sem separação dos mutuários por classe de renda, tendo estes subsídios então beneficiado, em sua maioria, as famílias de renda média e alta (SANTOS, 1999, p. 18).

\footnotetext{
${ }^{2}$ Garantia hipotecária é um direito real que grava coisa imóvel pertencente ao devedor ou a terceiro, sem a transmissão de posse ao credor. $\mathrm{O}$ credor tem o direito de promover a venda judicial do imóvel para pagamento, principalmente em caso de inadimplência. A modalidade mais utilizada atualmente é a Alienação Fiduciária que é o direito real, direito de propriedade com a intenção de garantia. Porém nesta modalidade o credor toma o bem em garantia mas o comprador fica impedido de negociar o bem com terceiros, verificada sua importância como sistema de garantia ao sistema financeiro será tratada de forma específica no item 2.3.1 deste trabalho.
} 
Com a extinção do BNH em 1986, suas atribuições foram divididas basicamente em duas instituições:

$\checkmark$ O Banco Central assumiu a posição de órgão normativo e fiscalizador do SBPE;

$\checkmark$ A Caixa Econômica Federal passou a ser a gestora do FGTS e agente financeiro do SBPE.

Desde a extinção do BNH até meados da década de 1990, poucas foram as políticas públicas voltadas ao setor habitacional; consequentemente, não houve postura governamental suficiente para reverter o quadro da crise existente.

A figura abaixo apresenta de forma simplificada os principais programas federais propostos desde a criação do SFH até a implantação do último, em 2009.

\section{FIGURA 02 - PRINCIPAIS PROGRAMAS FEDERAIS}

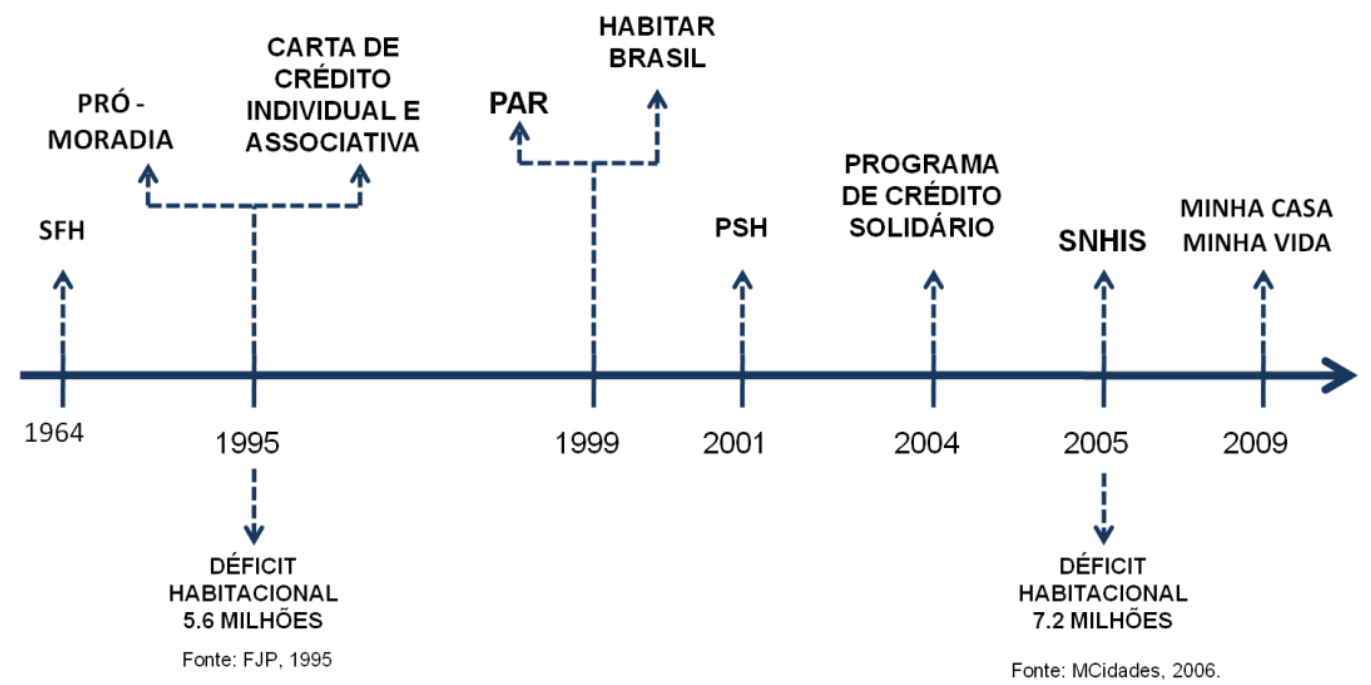

Fonte: Elaborado pela autora, utilizando dados FJP, 1995 e Ministério das Cidades, 2006.

\subsubsection{PRINCIPAIS FONTES DE RECURSOS DO SFH}

Em 1995, a Fundação João Pinheiro constata um déficit habitacional em torno de 5,6 milhões de moradias, sendo $85 \%$ desse déficit representado por famílias de renda de até cinco salários mínimos. No mesmo período, foram criados os programas: Pró-Moradia (infraestrutura) e Carta de Crédito Individual e Associativa, que, de acordo com dados da SEPURB, beneficiou aproximadamente 265 mil famílias no período de 01/95 a 07/98. 
FIGURA 03 - AS RESPECTIVAS FONTES DE RECURSOS DOS PROGRAMAS

HABITACIONAIS DE 1964 A 2009

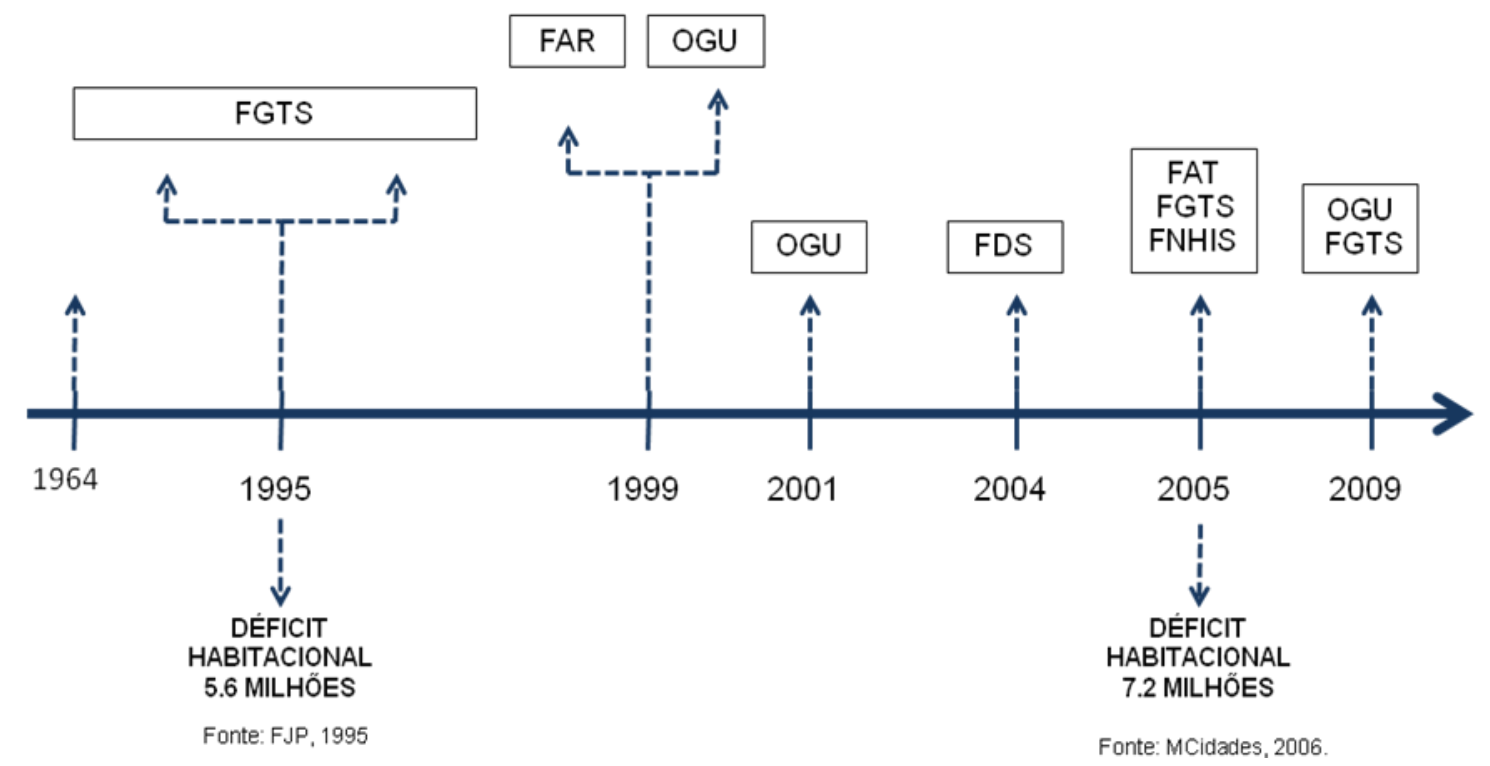

Fonte: Elaborado pela autora, utilizando dados FJP, 1995 e Ministério das Cidades, 2006.

Em 1995, os programas lançados possuíam o FGTS como fonte de recursos, sendo que, nas cartas de crédito, o benefício era para os tomadores finais do crédito habitacional, e no Programa Pró-Moradia o financiamento voltava-se para implantação de infraestrutura urbana.

Em 1999, foi criado o Plano de Arrendamento Residencial (PAR), que tinha como fonte de recurso o Fundo de Arrendamento Residencial (FAR) e o Habitar Brasil, cuja fonte de recurso era o OGU, programa destinado a financiar infraestrutura. O Habitar Brasil conseguiu atingir um número maior de investimentos, de famílias beneficiadas em municípios diversos, gerar mais empregos, além de realizar mais obras.

Em 2001, surge o Programa Subsídio a Habitação (PSH), que objetiva oferecer acesso à moradia adequada por intermédio de concessão de subsídios, sendo operado com recursos provenientes do OGU e contando com a contrapartida dos estados e municípios, que complementam os subsídios oferecidos pelo programa.

Em 2004, é criado o Programa de Crédito Solidário, voltado ao atendimento de unidades habitacionais e sendo organizado por cooperativas ou associações. O sistema utilizado pelo programa engloba o financiamento à produção e à comercialização. É operado com recursos do Fundo de Desenvolvimento Social (FDS), do qual a Caixa Econômica Federal (CEF) é o agente operador. 
Em 2005, é aprovada a lei que trata do SNHIS - apesar de não se caracterizar como um programa propriamente dito, merece destaque, uma vez que tem como objetivo integrar todos os programas e projetos destinados à HIS, implementar políticas e programas de investimentos e subsídios à população de baixa renda, viabilizando acesso à terra urbanizada e à habitação sustentável para população de menor renda.

Em 2009, foi lançado o programa habitacional "Minha Casa, Minha Vida", num cenário de desaceleração brusca da economia e baixa produção de unidades habitacionais, cujo objetivo declarado é a produção de um milhão de unidades para famílias com renda de até dez salários mínimos por meio da disponibilização de R $\$ 34$ bilhões em investimentos na construção civil. O programa objetiva, de maneira mais clara, conservar os empregos criados pelo setor produtivo da construção civil no período pré-crise, mantendo-o aquecido por meio do aumento da oferta de crédito.

A tabela abaixo apresenta a relação dos números de unidades propostas para o programa "Minha Casa, Minha Vida" para cada faixa de renda dentro de cada área de atuação do programa.

TABELA 01 - ÁREA DE ATUAÇÃO E NÚMERO DE UNIDADES PROPOSTAS NO PERÍODO

\begin{tabular}{|c|c|c|c|}
\cline { 2 - 4 } \multicolumn{1}{c|}{} & 0 A 3 SALÁRIOS MÍNIMOS & $\begin{array}{c}3,1 \text { A } 6 \text { SALÁRIOS } \\
\text { MÍNIMOS }\end{array}$ & $\begin{array}{c}6,1 \text { A } 10 \text { SALÁRIOS } \\
\text { MÍNIMOS }\end{array}$ \\
\hline $\begin{array}{c}\text { No DE UNIDADES } \\
\text { PROPOSTAS }\end{array}$ & 400 mil unidades em 2 anos & 400 mil unidades em 2 anos & 200 mil unidades em 2 anos \\
\hline ÁREA DE ATUAÇÃO & $\begin{array}{c}\text { CAPITAIS E REGIÕES } \\
\text { METROPOLITANAS/ } \\
\text { MUNICÍPIOS COM MAIS DE } \\
\text { 100 MIL HABITANTES }\end{array}$ & $\begin{array}{c}\text { CAPITAIS E REGIÕES } \\
\text { METROPOLIIIIOS COM MAIS DE } \\
\text { 100 MIL HABITANTES }\end{array}$ & \\
\hline
\end{tabular}

Fonte: Ministério das Cidades (2009).

As fontes de recursos do programa estão divididas de acordo com a tabela abaixo: 
TABELA 02 - FONTE DOS RECURSOS DO PROGRAMA, EM BILHÕES DE REAIS

\begin{tabular}{|c|c|c|c|}
\hline PROGRAMA & UNIÃO & FGTS & TOTAL \\
\hline SUBSÍDIO PARA MORADIA & 16,00 & - & 16,00 \\
\hline SUBSÍDIO PARA FINANCIAMENTOS DO FGTS & 2,50 & 7,50 & 10,00 \\
\hline FUNDO GARANTIDOR EM FINANCIAMENTOS DO FGTS & 2,00 & - & 2,00 \\
\hline REFINANCIAMENTO DE PRESTAÇÕES & 1,00 & - & 1,00 \\
\hline SEGURO EM FINANCIAMENTOS DO FGTS & 1,00 & - & 1,00 \\
\hline TOTAL & 20,50 & 7,50 & 28,00 \\
\hline PROGRAMA & UNIÃO & FGTS & TOTAL \\
\hline FINANCIAMENTO A INFRA-ESTRUTURA & 5,00 & - & 5,00 \\
\hline PROGRAMA & UNIÃO & BNDES & TOTAL \\
\hline FINANCIAMENTO À CADEIA PRODUTIVA & - & 1,00 & 1,00 \\
\hline
\end{tabular}

Fonte: CBIC (2009).

Os princípios do programa podem ser agrupados da seguinte forma:

- CRÉDITO E RECURSOS

$\checkmark$ Foco do subsídio para famílias com renda de até 10 salários mínimos;

$\checkmark$ Subsídio direto para famílias, conforme faixa de renda;

$\checkmark$ Limite do valor das unidades financiadas pelo programa de até R\$130.000,00;

$\checkmark$ Comprometimento máximo de renda das famílias em até $20 \%$;

$\checkmark$ Prestações somente a partir da entrega do imóvel;

$\checkmark$ Fundo Garantidor;

$\checkmark$ Linha de crédito específica para infraestrutura;

$\checkmark$ Linha de crédito para desenvolvimento tecnológico das empresas;

$\checkmark \mathrm{R} \$ 34$ bilhões em recursos para subsídio e financiamento.

- DESONERAÇÃO, TRIBUTAÇÃO E DESBUROCRATIZAÇÃO

$\checkmark$ Desoneração de tributos federais PIS + COFINS + IRPJ + CSLL ( de 7\% para 1\%) em imóveis de até $\mathrm{R} \$ 60$ mil;

$\checkmark$ Redução das taxas de emolumentos para o incorporador (90\% a $75 \%$ conforme valor do imóvel);

$\checkmark$ Isenção no seguro para mutuários com renda até seis salários mínimos;

$\checkmark$ Redução nas custas cartoriais com gratuidade para famílias com renda até 3 salários e desconto entre $80 \%$ e $95 \%$ nas outras faixas até 10 salários. 
O governo ainda propõe uma linha especial de financiamento na ordem de $\mathrm{R} \$ 5$ bilhões para incentivar as construtoras a investir em infra-estrutura, além de facilitar pagamentos que devem ocorrer em até 36 meses, com carência de 18 meses, pois estima ser este o prazo de conclusão da obra. O Banco Nacional de Desenvolvimento Social (BNDES) pretende oferecer linhas de financiamento subsidiadas à cadeia produtiva, promovendo assim competitividade, elevando o nível de qualidade das construtoras e fornecedores, além de estimular investimentos em alternativas construtivas industrializadas com menor custo, menor prazo de entrega e menor impacto ambiental, e também maior qualidade na construção.

Apesar de o programa apresentar vários aspectos positivos, ele contém algumas fragilidades, em especial quanto à sua sustentabilidade financeira; poderia, inclusive, ter sido denominado pelo governo "pacote habitacional", uma vez que possui valores e metas específicas e definidas ${ }^{3}$.

\subsection{A PRINCIPAL FONTE DE RECURSO DO SFH PARA HABITAÇÕES POPULARES:} O FGTS

O FGTS, fonte com maior volume de recursos onerosos ${ }^{4}$, é tratado de forma específica neste capítulo para posteriormente ser comparado, por similaridade, ao sistema mexicano de captação de recursos para financiamento.

Criado pela Lei 5.107, de 13 de setembro de 1966, o FGTS tinha como objetivo principal assegurar proteção financeira aos trabalhadores em situação de desemprego ou aposentadoria e ser utilizado como fonte de recursos para aquisição da casa própria.

Carvalho (2000) ressalta que o FGTS tinha ainda outro objetivo, que era a eficiência alocativa do mercado de trabalho, ou seja, flexibilizar as demissões e acabar com a estabilidade aos dez anos de serviço, o que obrigava as empresas a oferecer provisão para essas demissões.

O fundo tinha, portanto, três metas principais: seguro social, eficiência alocativa do mercado de trabalho e financiamento à habitação, saneamento e infraestrutura.

\footnotetext{
${ }^{3}$ O programa não será fruto de análise neste estudo, uma vez que o objetivo aqui não é discutir os programas existentes. Além disso, os resultados finais do programa ainda não haviam se concretizado quando da elaboração desta pesquisa. Trata-se somente de apontar as propostas de implementação efetuadas pelo atual governo federal.

${ }^{4}$ Recursos onerosos são aqueles utilizados nos financiamentos e sobre os quais, além da correção monetária, são cobrados juros, como retorno do financiamento (Medeiros, 2007, p. 56).
} 
Em 1990, com o objetivo de democratizar as decisões sobre disponibilização de crédito e investimentos que gerassem rentabilidade adequada à sustentabilidade do Fundo, foi criado, por meio da Lei 8.036/1990, o Conselho Curador, que estabelecia normas e diretrizes para aplicação de seus recursos. Composto por representantes dos trabalhadores, empregadores, órgãos e entidades governamentais na forma estabelecida pela legislação, ao Conselho Curador também cabe estabelecer as diretrizes e os programas de alocação de recursos do FGTS, de acordo com os critérios dessa lei, da política nacional de desenvolvimento urbano e das políticas setoriais de habitação popular, entre outras (MEDEIROS, 2007).

O funcionamento do FGTS tem algumas características que o estruturam. Primeiramente, são realizados depósitos pelos empregadores em contas vinculadas em nome dos trabalhadores, de forma que os recursos são centralizados e gerenciados pela Caixa Econômica Federal (CEF). São efetuados empréstimos entre o agente operador (CEF) e os demais agentes financeiros (inclusive a própria $\mathrm{CEF}$ ), os quais repassam os recursos aos agentes promotores (COHAB, incorporadoras e outras entidades). Desta forma, são concedidos financiamentos aos mutuários finais. Por fim, os retornos dos recursos são acrescidos de juros e outros encargos financeiros aplicáveis (CARVALHO, 2000).

Abaixo representação do funcionamento do FGTS:

FIGURA 04 - FLUXOGRAMA DO FUNCIONAMENTO DO FGTS 


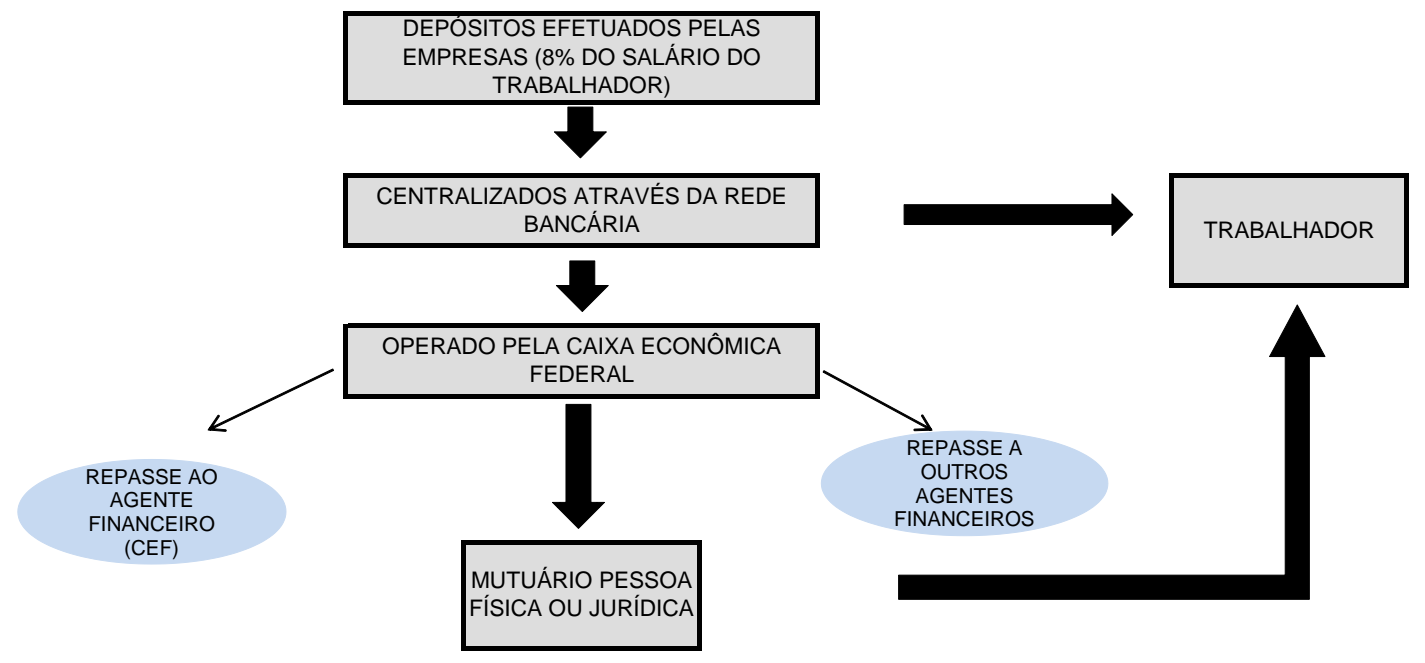

Fonte: Carvalho (2000) - adaptado

O agente operador do FGTS é a Caixa Econômica Federal (CEF), e sua principal fonte de receita é o depósito de $8 \%$ do salário de cada trabalhador, efetuado pelo seu empregador em conta corrente vinculada a essa instituição. Os principais fluxos de saída dessa conta são saques efetuados quando o trabalhador é demitido, aposenta-se ou adquire imóvel próprio.

Segundo a Resolução 460/2004 do Conselho Curador do FGTS, este tem como fluxo de entrada de recursos, no mínimo, os seguintes itens: depósitos efetuados pelo empregador nas contas vinculadas; retorno nas operações de crédito; multas; correção monetária e juros moratórios; receitas financeiras líquidas; arrecadação de contribuição social; créditos securitizados do FCVS; operações compromissadas; outras receitas.

São consideradas saídas de recursos: saques de contas vinculadas; desembolso das operações de crédito; encargos autorizados pelo Conselho Curador; pagamentos de créditos complementares; resgate de operações compromissadas.

A capacidade de investimento do FGTS depende de vários fatores; o principal deles é o nível de emprego formal, que gera renda para garantir adimplência aos financiamentos, além de custos operacionais. Nos anos 1980, tendo sido verificada a quantidade de concessão de créditos de baixa qualidade e elevados índices de inflação, o FGTS passou por um período de corrosão de seus recursos, retomando lentamente sua capacidade de investimento a partir do final da década de 1990, quando foi tomada uma importante decisão: a segregação dos balanços do FGTS e CEF, até então feitos conjuntamente. 
GRÁFICO 05 - A ARRECADAÇÃO DO FGTS - VOLUME EM BILHÕES DE REAIS E PERCENTUAL DE CRESCIMENTO ANUAL

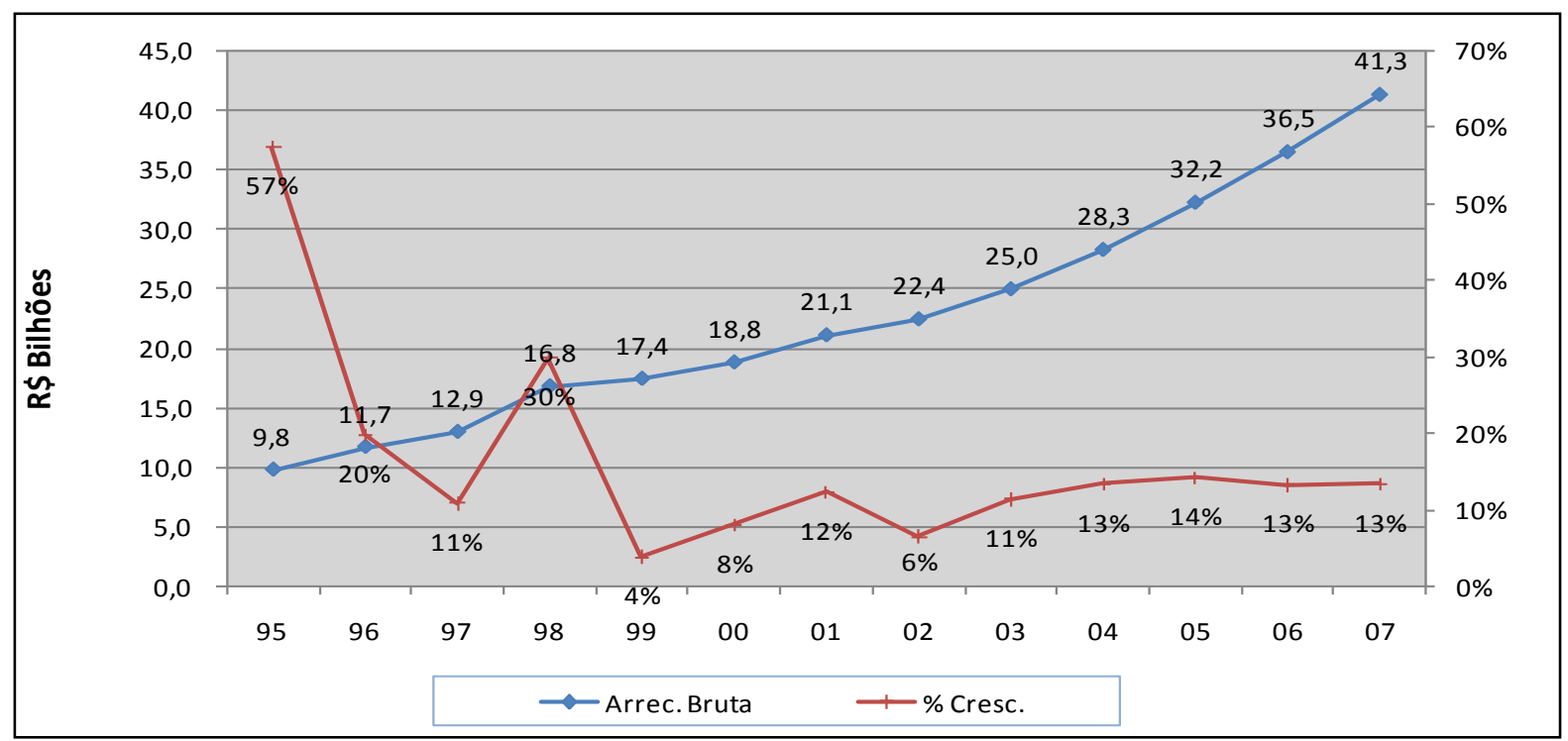

Fonte: BACEN, 2008.

No gráfico 05 nota-se que foram grandes as oscilações ocorridas no período de 1995 a 2002 em relação à arrecadação do FGTS. Enquanto os anos iniciais (1995 a 1997) ainda apresentam oscilações que poderiam ser atribuídas aos ajustamentos pelos quais passou a economia logo após o fim do período inflacionário, com o advento do Real, os anos de 1999 e 2002 foram marcados por quedas na arrecadação, devido às baixas taxas de crescimento da economia no período.

Com a estabilidade econômica, em 2004 foram retomadas algumas linhas de crédito para a produção, impulsionada pela alteração na legislação vigente, como por exemplo, a Lei que trata do Patrimônio de Afetação que separa cada empreendimento objeto do financiamento de outros ativos da empresa, protegendo o agente financeiro no caso de falência da incorporadora. O gráfico 06 mostra o aumento significativo dos recursos na década de 2000. 


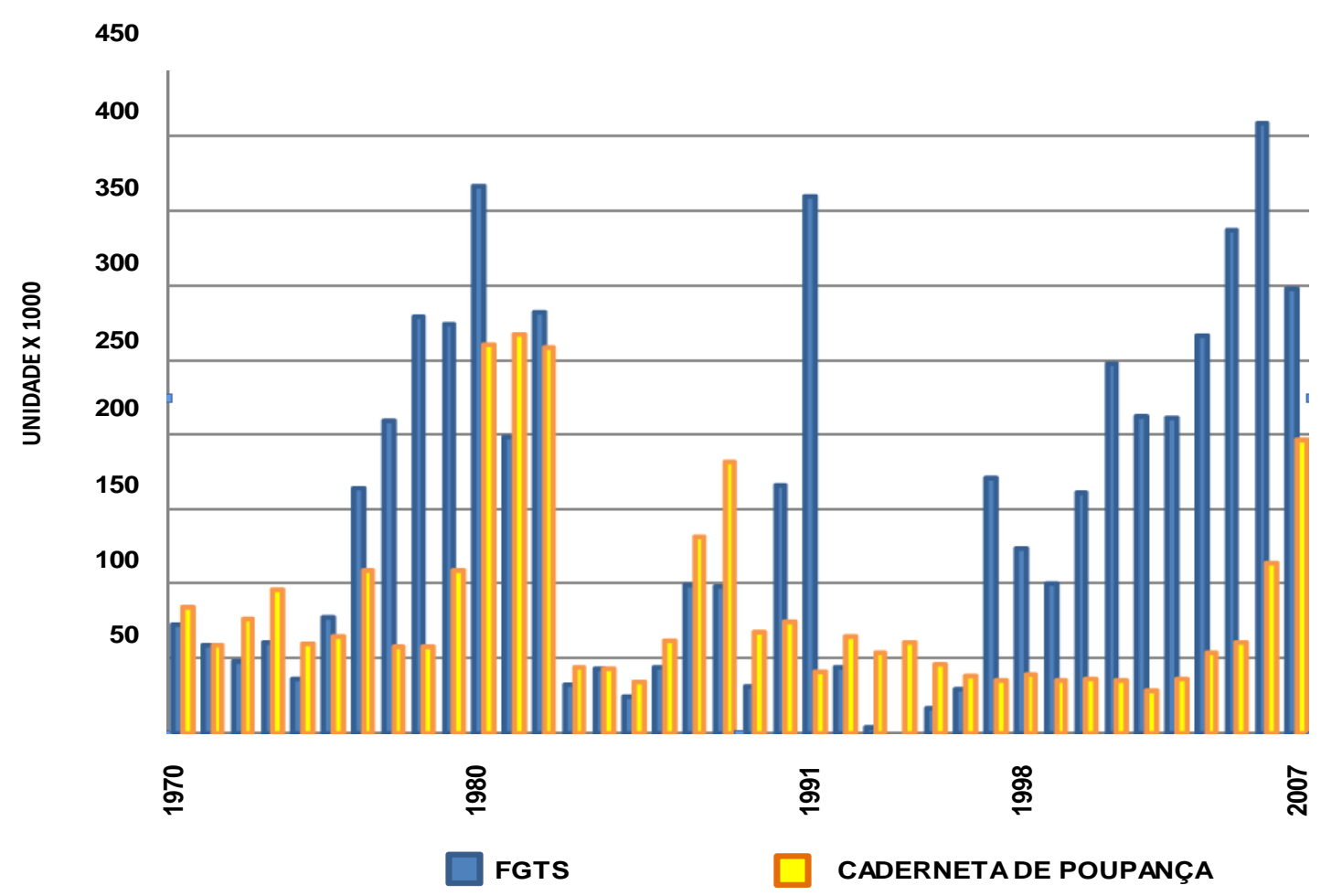

Fonte: BACEN, 2008.

O gráfico demonstra também a diferença no desempenho do FGTS e Caderneta de Poupança no número de unidades financiadas pelo SFH. Pode-se observar que, na década de 1980, as duas fontes de recursos do SFH, o FGTS e as cadernetas de poupança, tiveram seu melhor desempenho, impulsionado pelo crescimento econômico que marcou aquele período. O número de unidades financiadas atingiu seu máximo, resultado obtido pela cooperação das duas fontes de financiamento.

\subsubsection{SOBRE A ALOCAÇÃO DOS RECURSOS DO FGTS}

As diretrizes de alocação dos recursos do FGTS são realizadas de acordo com a resolução $n^{\circ} 460$, de 14 de dezembro de 2004, que também estabelece a elaboração das propostas orçamentárias anuais. Portanto, o Conselho Curador do FGTS não executa programas nem tampouco ações de governo. Sua função, entre outras, é adotar indicadores sociais, objeto das Políticas Públicas de Habitação e de Saneamento Básico. Em decorrência disso, os recursos são alocados por área de aplicação e unidades da Federação de acordo com 
indicadores do Déficit Habitacional/ População Urbana (área de habitação popular) e Déficit de água e esgoto/ população urbana (área de saneamento básico).

Desta forma, o FGTS tem sido a principal, e muitas vezes, a única fonte de recursos para investimento tanto na área de habitação quanto na área de saneamento. No período de 1995 a 2008, as aplicações alcançaram o montante de R\$71,5 bilhões. Em 2008, foram aplicados $\mathrm{R} \$ 10,02$ bilhões, além da contratação de 182.121 operações de crédito (Dados do relatório de gestão do FGTS de 2008).

As aplicações dos recursos do FGTS, de acordo com a Resolução 460/2004, adotaram as seguintes definições:

$\checkmark$ Empréstimos - operações de crédito entre o agente operador e o agente financeiro;

$\checkmark$ Financiamento - operações de crédito entre o agente financeiro e o mutuário, com recursos originários da operação de empréstimo;

$\checkmark$ Agentes financeiros - os agentes financeiros do SFH;

$\checkmark$ Mutuários - pessoas físicas ou jurídicas definidas pelos programas de aplicação do FGTS.

No segundo semestre de 2008, com a forte desaceleração do setor imobiliário norte americano, e seu impacto na economia global sob a forma de contratação de crédito e aversão ao risco, inicia-se uma crise financeira, levando grandes economias mundiais (EUA, Japão, Alemanha) à recessão e, consequentemente, à paralisação de investimentos, redução da produção em geral e ao aumento do desemprego.

Diante desse cenário, caracterizado pela escassez de crédito e falta de liquidez no mercado financeiro, o Conselho Curador do FGTS (CCFGTS) atuou em decisões voltadas ao restabelecimento do fluxo de crédito, proporcionando resultados positivos de arrecadação $\mathrm{R} \$ 3,25$ bilhões em 2007 e R \$6,03 bilhões em 2008 (Dados do relatório de gestão do FGTS de 2008).

Na tabela 04 observa-se a proposta de valores que o FGTS aloca na economia no ano de 2009, com a finalidade principal de analisar os usos do recurso: 
TABELA 03 - RECURSOS DO FGTS ALOCADOS NA ECONOMIA EM 2008

\begin{tabular}{|c|r|}
\hline DISCRIMINAÇÃO DO GASTO & VALOR (R\$ MIL) \\
\hline $\begin{array}{c}\text { APLICAÇÕES: HABITAÇÃO/ SANEAMENTO/ } \\
\text { CRI/ INFRAESTRUTURA/ PRÓ COTISTA E } \\
\text { DESEMBOLSOS }\end{array}$ & 17.361 .613 \\
\hline SAQUES (RESCISÃO, MORADIA E OUTROS) & 45.710 .064 \\
\hline ENCARGOS DO FGTS & 2.375 .343 \\
\hline PLANOS ECONÔMICOS & 1.860 .000 \\
\hline APLICAÇÃO DE COTAS: FI-FGTS & 10.000 .000 \\
\hline TOTAL & 77.307 .020 \\
\hline
\end{tabular}

Fonte: Ministério das Cidades apud relatório de gestão FGTS 2008

Em junho de 2007, por meio da lei n¹1.491, no âmbito do Pacote de Aceleração do Crescimento, é regulamentado o FII-FGTS, objetivando-se a aplicação de recursos do FGTS a investimentos em empreendimentos dos setores de energia, rodovia, ferrovia, hidrovia, portos e saneamento, de acordo com os critérios estabelecidos pelo Conselho Curador. Tanto o conselho curador do FGTS quanto a Comissão de Valores Mobiliários - CVM emitiram as normas necessárias à regulamentação e ao funcionamento do FII-FGTS.

Em 2008, foram aprovados 57 investimentos em projetos dos setores de energia, ferrovia, portos, rodovias e saneamento, no montante de $\mathrm{R} \$ 11,31$ bilhões, de acordo com a tabela 03.

TABELA 04 - INVESTIMENTOS/ SETOR EM 2008

\begin{tabular}{|c|r|r|}
\hline INVESTIMENTOS POR SETOR & PERCENTUAL & VALOR (R\$ MIL) \\
\hline ENERGIA & $80,60 \%$ & 9.117 .927 \\
\hline FERROVIA & $8,20 \%$ & 923.037 \\
\hline PORTOS & $6,30 \%$ & 708.920 \\
\hline RODOVIAS & $4,40 \%$ & 500.000 \\
\hline SANEAMENTO & $0,50 \%$ & 60.540 \\
\hline TOTAL & $100,00 \%$ & 11.310 .424 \\
\hline
\end{tabular}

Fonte: Relatório de gestão FGTS 2008.

A carteira de investimentos do FII FGTS tem retorno projetado de TR $+6 \%$ ao ano. O relatório de gestão do FGTS indica que, entre as fases de construção e operação dos 
empreendimentos, os investimentos promovem: 608.147 mil empregos diretos $(65,69 \%)$ e 317.548 mil empregos indiretos $(34,04 \%)$, demonstrando assim a importância da aplicação dos recursos do fundo em outras áreas.

Em dezembro de 2008, no intuito de fazer frente à crise financeira americana, o CCFGTS autorizou a alocação de $\mathrm{R} \$ 3$ bilhões para a aquisição de direitos creditórios vinculados ao desenvolvimento de projetos no setor imobiliário, com $7 \%$ a.a + TR para empreendimentos na área de habitação popular e $9 \%$ a.a + TR para empreendimentos não enquadrados na área de habitação popular. Inicialmente, as instituições financeiras atuaram nesses investimentos, na estruturação dos fundos (FII - Fundos de Investimento Imobiliário/ FIDCs - Fundos de Investimentos em Direitos Creditórios e Debêntures) para lançamento no mercado; posteriormente, eles são adquiridos pelo agente operador do FGTS (Caixa Econômica Federal), que, finalmente, financia as unidades habitacionais aos mutuários finais.

No gráfico 07 encontra-se uma análise da alocação do FGTS distribuída por faixa de renda no período de 2001 a 2007. Nota-se um crescimento contínuo, que se inicia em 2004 atingindo seu ápice em 2006, porém não ultrapassando mais do que 220.000 unidades para a faixa de renda de até três salários mínimos, em que se encontra, aproximadamente, $96,30 \%$ do déficit habitacional brasileiro. Após esse período, o número de unidades produzidas pela alocação dos valores do fundo passa por um período de declínio, atingindo em 2007 pouco mais de 65.000 unidades para a mesma faixa de renda.

\footnotetext{
GRÁFICO 07 - ALOCAÇÃO DE RECURSOS DO FGTS PARA AQUISIÇÃO DE UNIDADES DISTRIBUÍDA POR FAIXA DE RENDA NO PERÍODO DE 2001 - 2007
} 


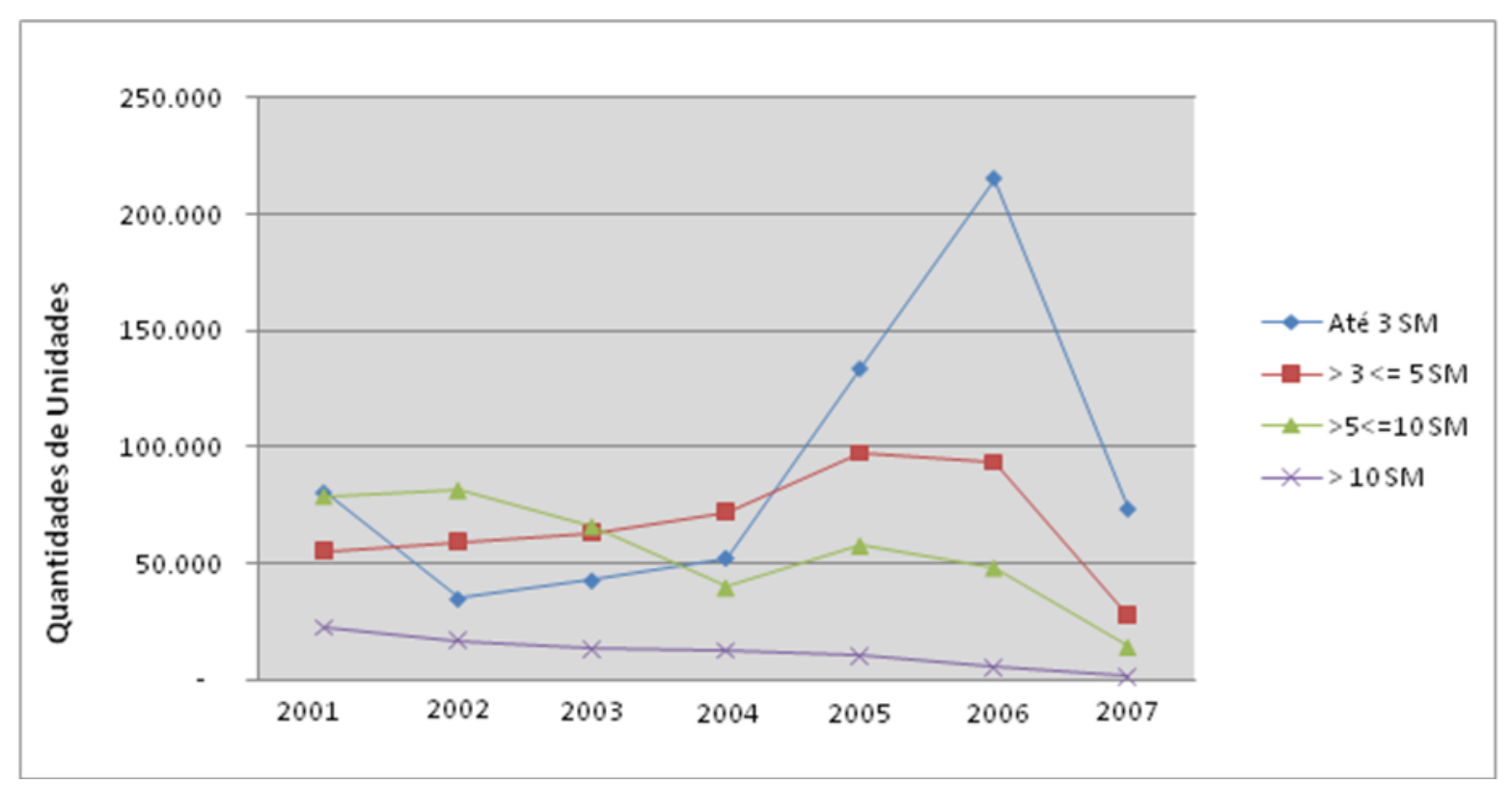

Fonte: Caixa Econômica Federal (2007).

\subsubsection{SOBRE OS FINANCIAMENTOS DOS RECURSOS DO FGTS}

Existem duas modalidades de financiamentos com os recursos do FGTS: para o mutuário final, na comercialização de imóveis prontos, novos ou usados, e para a produção de unidades habitacionais.

O volume de financiamentos para aquisição de imóveis novos diretamente do tomador final tem efeito econômico similar àqueles voltados à produção de empreendimentos. Foi verificado que a aquisição de imóveis novos é resultado, principalmente, de empreendimentos da indústria da construção civil, com recursos próprios, sendo que o financiamento é vital para a comercialização dos estoques. Embora tenha importante participação de grandes construtoras nesse modelo (produzir com recursos próprios e comercializar via financiamento ao adquirente final), ele é imprescindível para as pequenas e médias, que, muitas vezes, não têm acesso ao financiamento direto à produção.

O financiamento de imóveis usados tem a função de dar liquidez ao mercado imobiliário e alavancar o mercado de novos.

Em 2009, a participação de imóveis novos respondeu por 55,20\% do total aplicado. Em mercados imobiliários "maduros" como, por exemplo, os EUA, a participação percentual de imóveis usados no total dos financiados é superior ao de novos. No caso brasileiro, é natural uma participação expressiva de imóveis novos, dado o déficit habitacional elevado. 
No gráfico a seguir pode-se analisar o quanto de recursos foram financiados à produção e o montante financiado à comercialização na última década:

\section{GRÁFICO 08 - FINANCIAMENTOS HABITACIONAIS COM RECURSOS DO FGTS, \\ EXCLUÍDO PROGRAMA DE MATERIAIS DE CONSTRUÇÃO AQUISIÇÃO NOVOS X FINANCIAMENTOS À PRODUÇÃO}

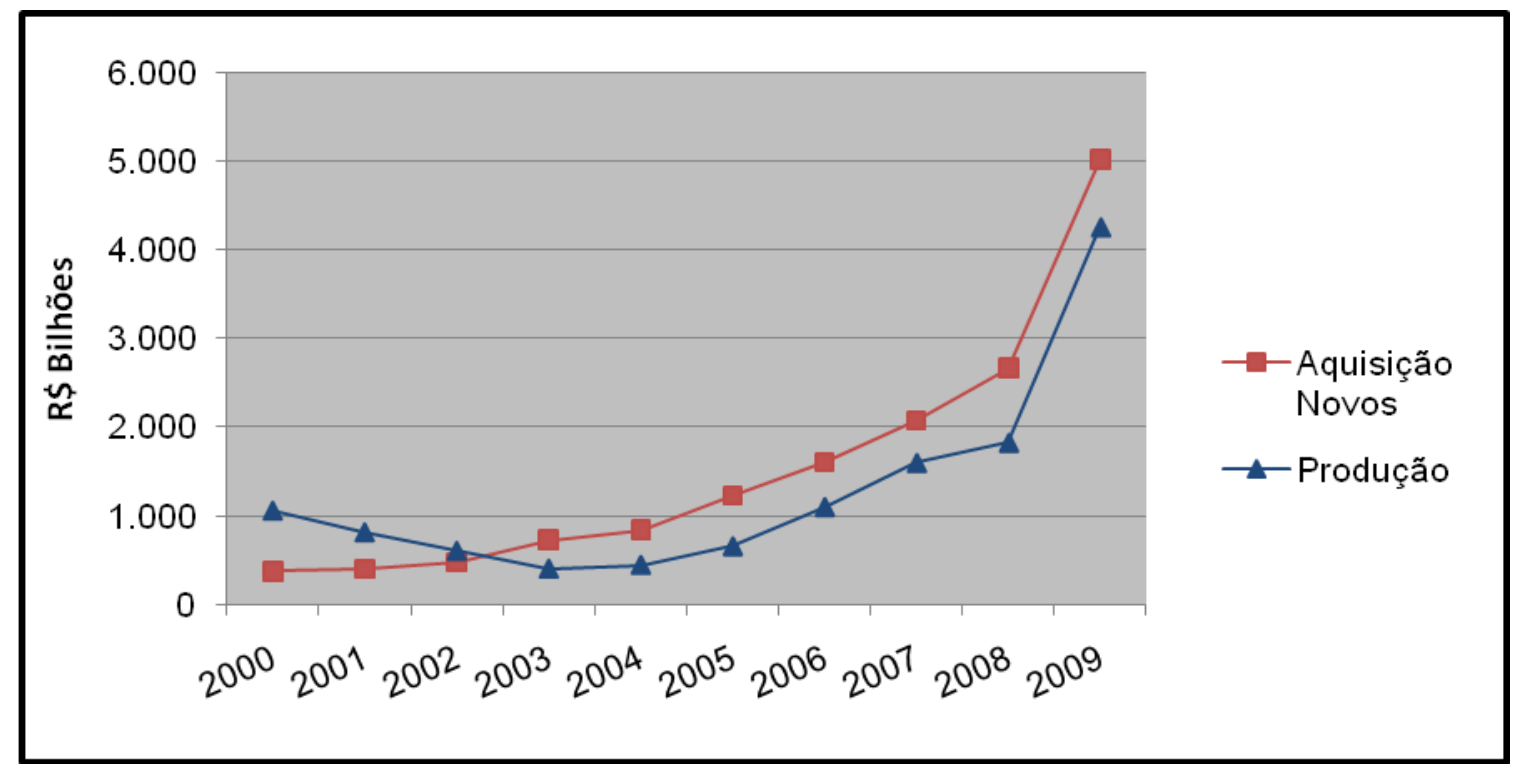

Fonte: Caixa Econômica Federal, 2009.

Verifica-se, pela análise, que o financiamento à comercialização foi crescente desde 2000 até o final da década, tendo um ápice em 2009. Já a análise relativa à produção indica um decréscimo nos três primeiros anos da década de 2000, passando a um crescimento contínuo de 2004 a 2009, sem, contudo, ultrapassar os financiamentos destinados à comercialização.

\subsubsection{SOBRE A ARRECADAÇÃO DO FGTS}

Conforme descrito anteriormente, o FGTS foi criado em 1967, com o objetivo principal de assegurar proteção financeira aos trabalhadores em situação de desemprego e aposentadoria e não com o objetivo de financiar habitação popular, infraestrutura, saneamento básico ou, ainda, setores como ferrovias ou rodovias.

Porém, tendo em vista o crescimento da arrecadação do FGTS, observado na Tabela 05, e a ausência de fontes de recurso para financiar acesso à habitação popular no país, 
agravando ao longo dos anos o déficit habitacional brasileiro, concluiu-se pela necessidade de disponibilizar esse recurso tanto para a produção dessas unidades habitacionais quanto concessão de créditos para aquisição de unidades por parte da população de baixa renda.

Um elemento importante para analisar o FGTS é a arrecadação bruta, pois representa as contribuições que são depositadas nas contas dos empregados pelas empresas, e reflete com propriedade uma característica: o nível de formalização do emprego.

\section{TABELA 05 - EVOLUÇÃO DA ARRECADAÇÃO DO FGTS}

\begin{tabular}{|c|c|c|c|c|c|c|}
\hline ANO & $\begin{array}{c}\text { ARRECADAÇÃO } \\
\text { BRUTA }\end{array}$ & $\begin{array}{c}\text { VARIAÇÃO } \\
\text { EM \% }\end{array}$ & SAQUES & $\begin{array}{c}\text { VARIAÇÃO } \\
\text { EM \% }\end{array}$ & $\begin{array}{c}\text { ARRECADAÇÃO } \\
\text { LÍQUIDA }\end{array}$ & $\begin{array}{c}\text { VARIAÇÃO } \\
\text { EM \% }\end{array}$ \\
\hline 2007 & 41.631 & - & 38.379 & - & 3.251 & - \\
\hline 2008 & 48.714 & $17,00 \%$ & 42.679 & $11,20 \%$ & 6.035 & $85,60 \%$ \\
\hline 2009 & 54.726 & $12,30 \%$ & 47.825 & $12,10 \%$ & 6.901 & $14,40 \%$ \\
\hline
\end{tabular}

OBS: Não inclui a arrecadação de Contribuição Social e pagamentos de saques referentes à LC 110/01.

Fonte: Caixa Econômica Federal 2009

Observa-se que, mesmo durante a crise de 2008, o patrimônio líquido do FGTS obteve 9,3\% de variação positiva em relação ao ano anterior. Tal estabilidade acabou consolidando essa fonte junto com o SBPE como os principais financiadores da produção e aquisição de habitações no Brasil.

Nos últimos três anos, houve um crescimento ininterrupto e significativo da arrecadação líquida do FGTS, sendo observada uma evolução nos valores de saques tendo em vista as demissões ocorridas entre o final do ano de 2008 e 2009, devido à crise financeira americana.

Analisando o perfil das operações de créditos efetuadas pelo FGTS, observa-se que os maiores valores aplicados são para habitação, seguidos por saneamento e infraestrutura. De acordo com a tabela $\mathrm{n}^{\circ} 06$, é possível verificar também que a taxa média de juros dessas operações é inferior nos empréstimos efetuados para a habitação, se comparados aos de outros setores. 
TABELA 06 - VALORES DAS OPERAÇÕES DE CRÉDITO

\begin{tabular}{|l|r|r|r|r|}
\hline \multirow{2}{*}{ ÁREA } & \multicolumn{1}{|c|}{$\mathbf{2 0 0 8}$} & \multicolumn{1}{c|}{ 2009 } & \multicolumn{1}{c|}{$\begin{array}{l}\text { PRAZO } \\
\text { MÉDIO }\end{array}$} & $\begin{array}{r}\text { TAXA MÉDIA } \\
\text { EM \% A.A. }\end{array}$ \\
\cline { 2 - 3 } & R\$ MILHÕES & R\$ MILHÕES & 133 & 5,309 \\
\hline HABITAÇÃO & 72.751 & 80.146 & 93 & 6,820 \\
\hline SANEAMENTO & 18.883 & 18.950 & 111 & 6,727 \\
\hline INFRA-ESTRUTURA & 9.453 & 8.860 & 337 & 5,691 \\
\hline TOTAL & 101.087 & 107.956 & & \\
\hline
\end{tabular}

Fonte: CEF apud Informativo GEAVO Dez/ 2009

Em relação às operações de crédito, verifica-se um retorno de 11,90\% no ano de 2008 e um percentual crescente no ano seguinte, chegando a 13,10\% no final de 2009.

TABELA 07 - RETORNO DAS OPERAÇÕES DE CRÉDITO

\begin{tabular}{|l|r|r|}
\hline \multirow{2}{*}{ ÁREA } & \multicolumn{1}{|c|}{$\mathbf{2 0 0 8}$} & \multicolumn{1}{c|}{ 2009 } \\
\cline { 2 - 3 } & R $\$$ MILHÕES & \multicolumn{1}{c|}{ R\$ MILHÕES } \\
\hline HABITAÇÃO & 7.627 & 9.819 \\
\hline SANEAMENTO & 774 & 1.086 \\
\hline INFRA-ESTRUTURA & 3.651 & 3.208 \\
\hline TOTAL & 12.052 & 14.113 \\
\hline ARRECADAÇÃO DE EMPRÉSTIMO & 12.052 & 14.113 \\
\hline SALDO DAS OPERAÇÕES DE CRÉDTO & 101.087 & 107.956 \\
\hline TOTAL & $11,90 \%$ & $13,10 \%$ \\
\hline
\end{tabular}

Fonte: CEF apud GEAVO, 2009

Analisando os dados do FGTS, observa-se que, nesse período, o fundo pouco foi afetado pela crise financeira americana no final de 2008. Tanto os retornos cresceram em 2009 em relação a 2008, quanto os financiamentos concedidos tiveram uma evolução positiva de quase 7\%, de acordo com o gráfico 09. Pode-se concluir, então, que o orçamento de arrecadação de 2007 a 2010 foi crescente e ininterrupto, passando de $\mathrm{R} \$ 12.450$ bilhões em 2007 a R \$56.213 bilhões em 2010. 


\section{GRÁFICO 09 - ORÇAMENTO DE ARRECADAÇÃO DO FGTS}

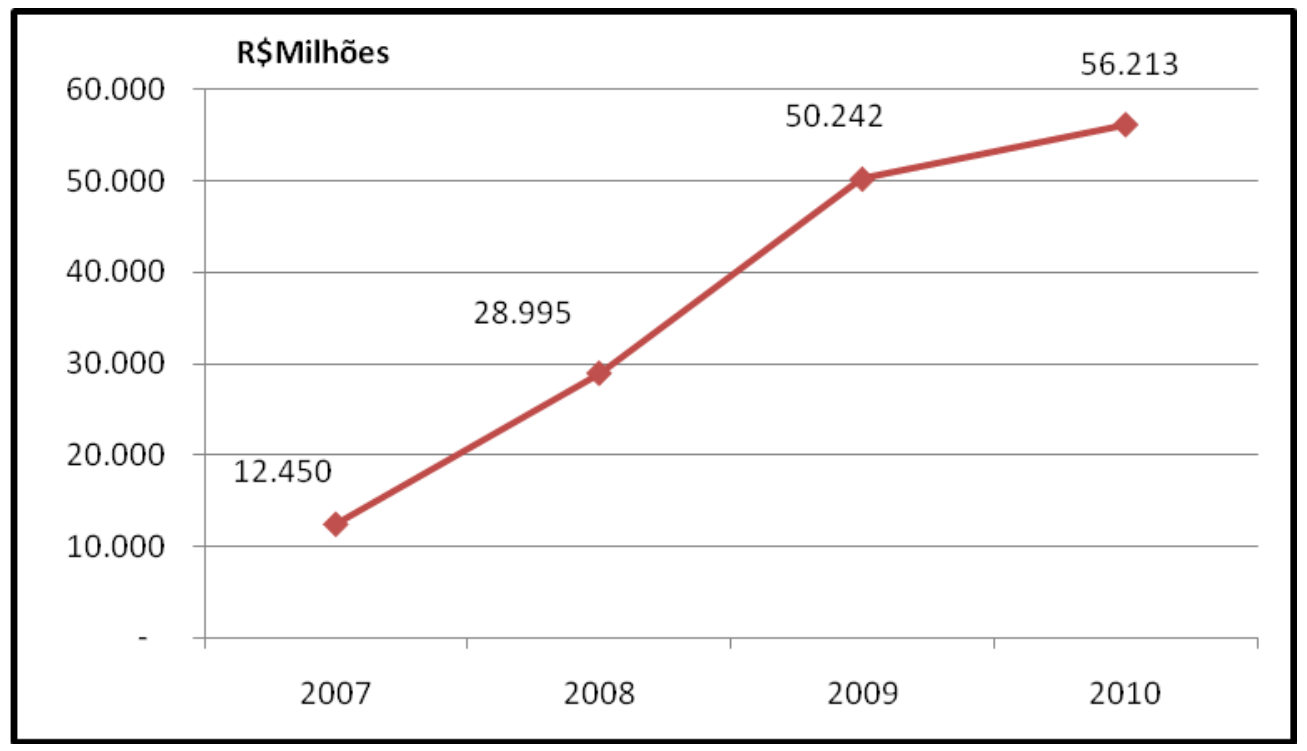

Fonte: Caixa Econômica Federal, 2009.

\subsubsection{PERFIL DOS MUTUÁRIOS QUE RECORREM AO FGTS POR FAIXA DE RENDA}

Quando se analisa o perfil dos contratos efetuados para pessoa física junto à Caixa Econômica Federal, observa-se que 33\% deles estão na faixa de renda de um a três salários mínimos, e o montante corresponde a $18 \%$ do valor contratado contra $16 \%$ dos contratos para a faixa de intervalo entre cinco e oito salários mínimos, com aproximadamente o mesmo montante contratado para a faixa de um a três salários mínimos: $22 \%$.

A partir dessa análise, conclui-se que, para a faixa de renda estudada neste trabalho, até cinco salários mínimos, o perfil das contratações junto ao FGTS representa $78,90 \%$ da quantidade de contratos e $69,90 \%$ dos valores contratados, sendo $30 \%$ dos recursos destinados a faixas de renda que possuem acesso a crédito via mercado, sem necessidade de recorrer aos recursos do FGTS. 


\section{GRÁFICO 10 - HABITAÇÃO - PERFIL DAS CONTRATAÇÕES COM PESSOA FÍSICA QUANTIDADE DE CONTRATOS X VALOR CONTRATADO}

Quantidade de contratos

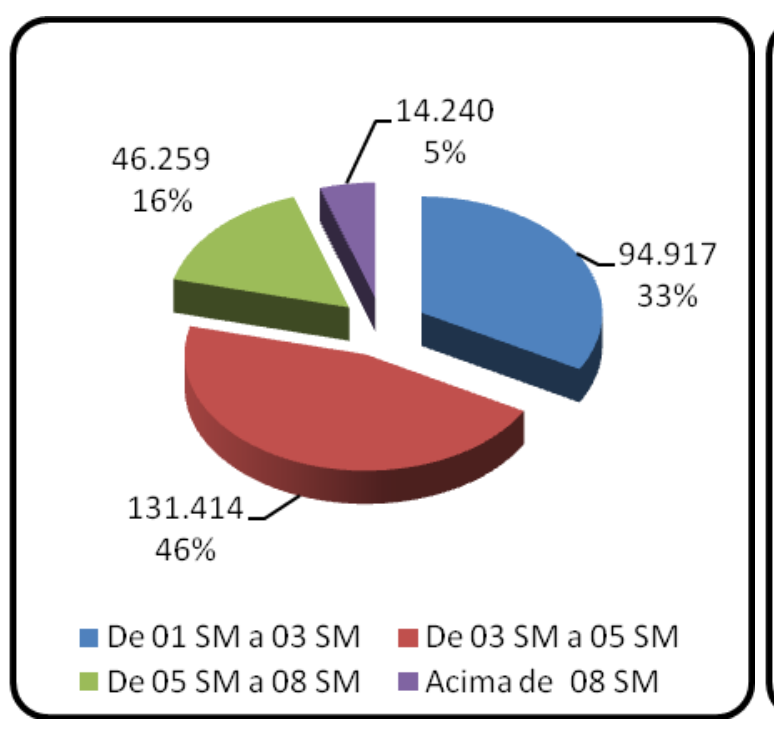

Até 5 SM: $78,9 \%$
Valor contratado - R \$ Milhões

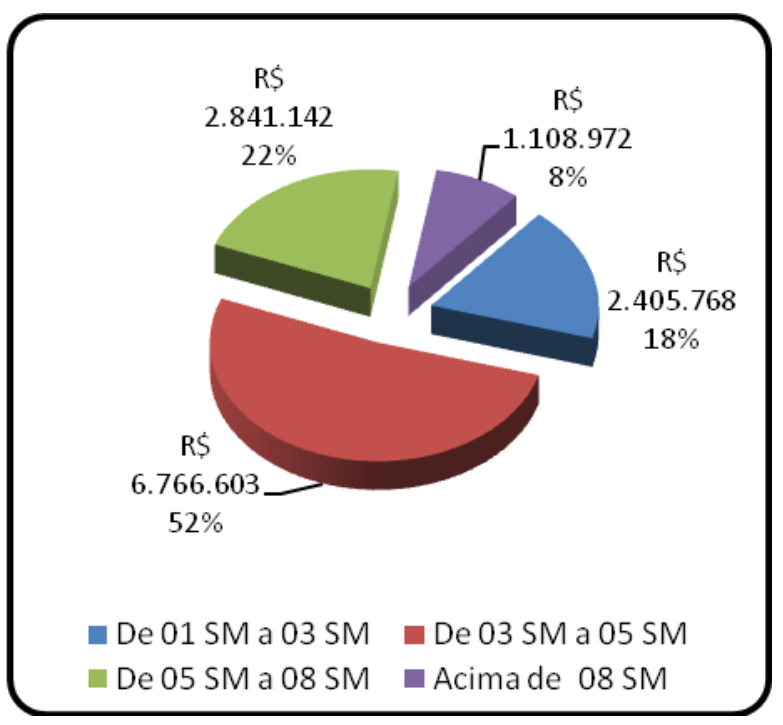

Até 5 SM: $69,9 \%$

Fonte: Caixa Econômica Federal, 2009.

No entanto, se esses perfis de contratações forem relacionados com os descontos efetuados por faixa de renda, observa-se que a quantidade de unidades de até um salário mínimo, por exemplo, é representada por $8 \%$ dos mutuários e $6 \%$ dos valores desembolsados. Por outro lado, analisando-se a faixa de renda acima de quatro salários mínimos, chega-se a $26 \%$ de unidades e $22 \%$ dos valores desembolsados. Fica clara também a importância do FGTS no financiamento para famílias com renda até oito salários mínimos, com empenho de até $92 \%$ dos recursos utilizados para essa faixa de renda. 


\section{GRÁFICO 11 - HABITAÇÃO - PERFIL DAS CONTRATAÇÕES COM PESSOA FÍSICA QUANTIDADE DE UNIDADES X VALORES DESEMBOLSADOS}

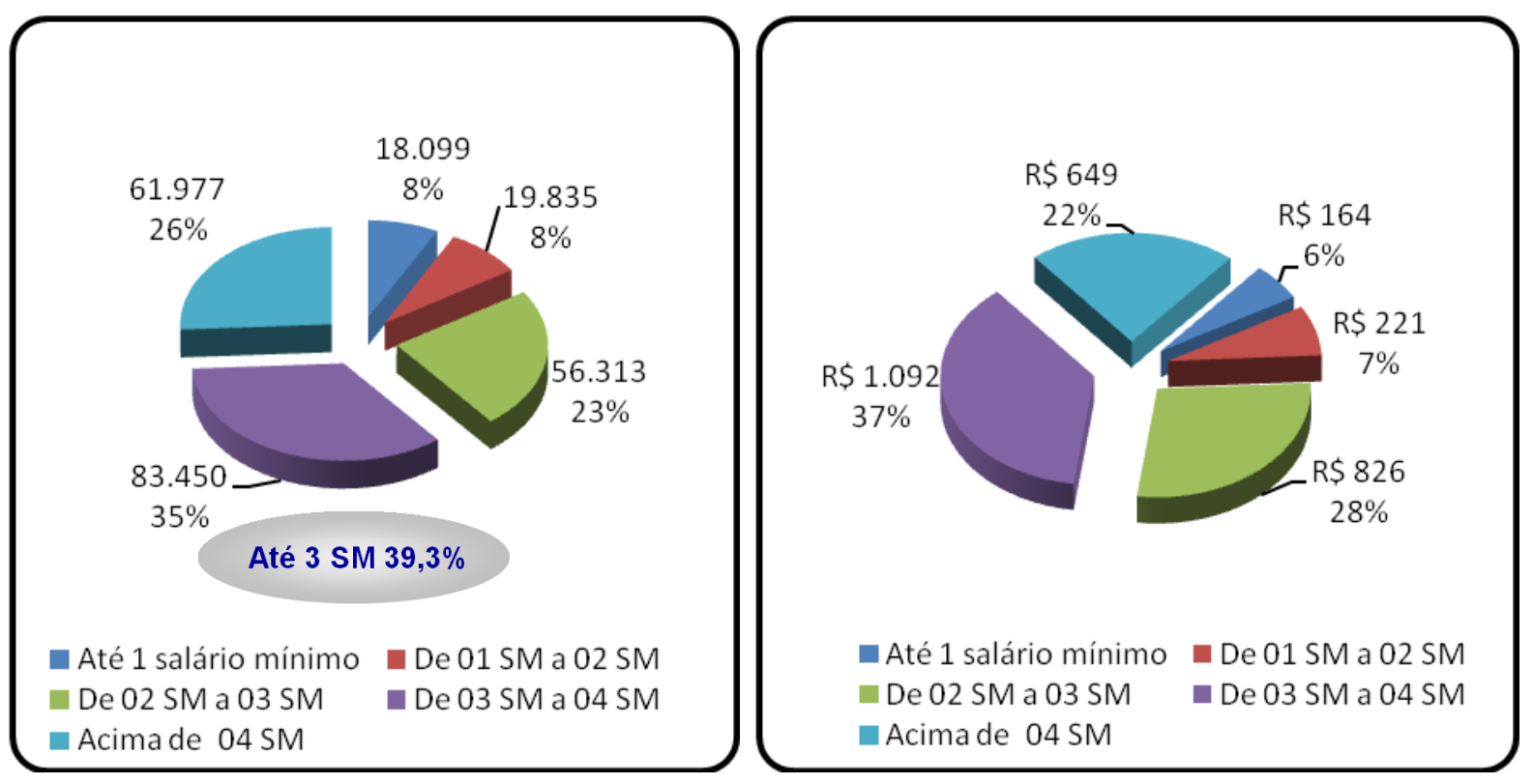

Fonte: Caixa Econômica Federal, 2009.

\subsubsection{DADOS DO FGTS NO FINANCIAMENTO HABITACIONAL BRASILEIRO}

Analisando o gráfico 12, observa-se que, três anos após a estabilidade da moeda brasileira, o FGTS possui algumas oscilações; porém, a partir da década de 2000, não financia número inferior a 200.000 unidades. Após 2004, passa por períodos crescentes de financiamento, graças principalmente à estabilidade econômica, não sofrendo nenhuma oscilação no final de 2008 (crise americana), chegando em 2009 a financiar número equivalente a 400.000 unidades habitacionais

Conclui-se que o número de financiamentos é crescente, e que os valores financiados por meio de recursos do FGTS são pequenos, se comparados às necessidades apresentadas pelo país. Porém, trata-se de uma importante, se não a mais importante fonte para habitação popular no Brasil, causando certa dependência do sistema desses recursos, o que não é desejável a médio e longo prazo, considerando que eventuais crises no emprego, por exemplo, 
causariam reflexos imediatos ao setor, com redução na disponibilidade desses recursos por parte do conselho gestor.

\section{GRÁFICO 12 - HABITAÇÃO - UNIDADES FINANCIADAS POR MEIO DO FGTS}

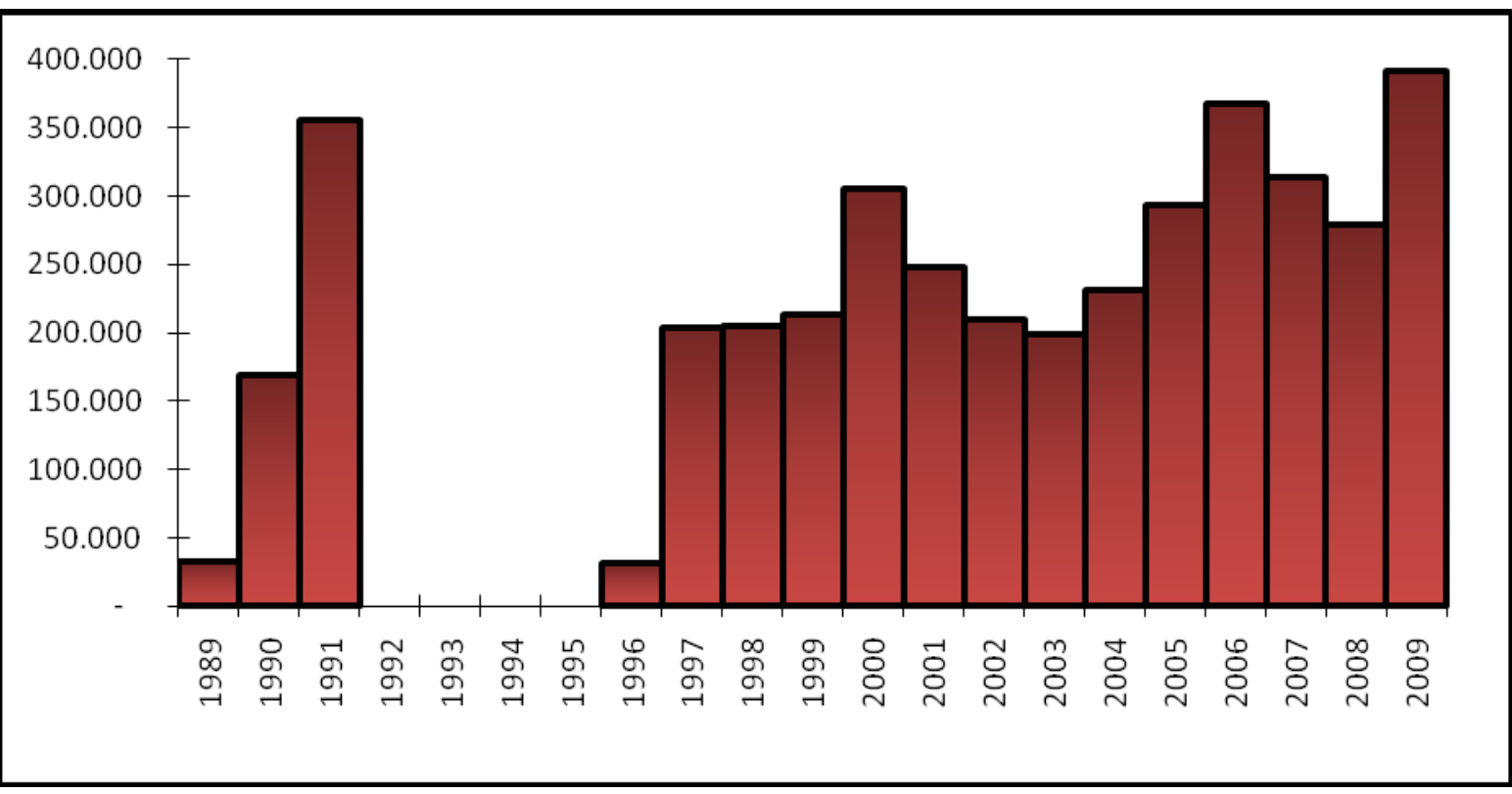

Fonte: Caixa Econômica Federal, 2009.

$\mathrm{Na}$ análise relativa ao gráfico 13 , que considera os valores financiados por meio do FGTS, observa-se que, dez anos após o Plano Real e com a moeda já em patamares estáveis, esses valores não ultrapassaram os $\mathrm{R} \$ 5.000 .000,00$ e que os investimentos passam a ser crescentes nos últimos cinco anos, chegando em 2009 a $\mathrm{R} \$ 15.000 .000,00$; ou seja, do início até o final da primeira década de 2000 ocorre um crescimento de aproximadamente três vezes do valor financiado inicialmente. 


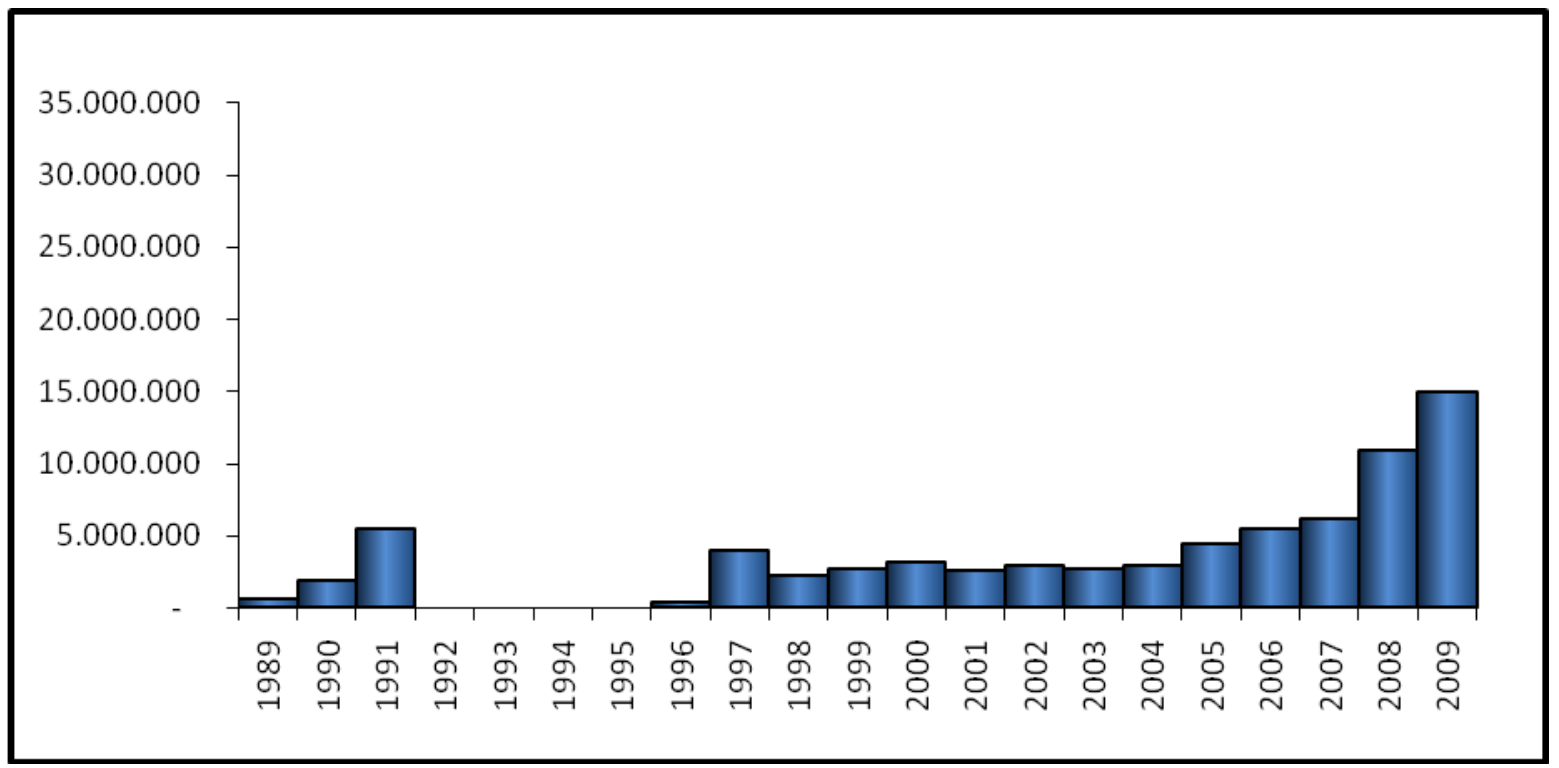

Fonte: Caixa Econômica Federal, 2009.

Quando o tema é subsídio, observa-se que o fundo passa de 141 milhões de reais no final da década de 1990 para 4 bilhões de reais no final da década seguinte. O crescimento é contínuo, sofrendo pequenas oscilações, mas observa-se que, nos últimos cinco anos, há uma maior preocupação com as políticas públicas voltadas para a questão, baseadas principalmente em uma economia sólida, com melhora significativa na capacidade de investimento do estado como um todo, e em particular do assalariado, que, com a liquidez do sistema, passou a contar com condições de financiamento compatíveis com sua capacidade de pagamento. 
GRÁFICO 14 - SUBSÍDIOS

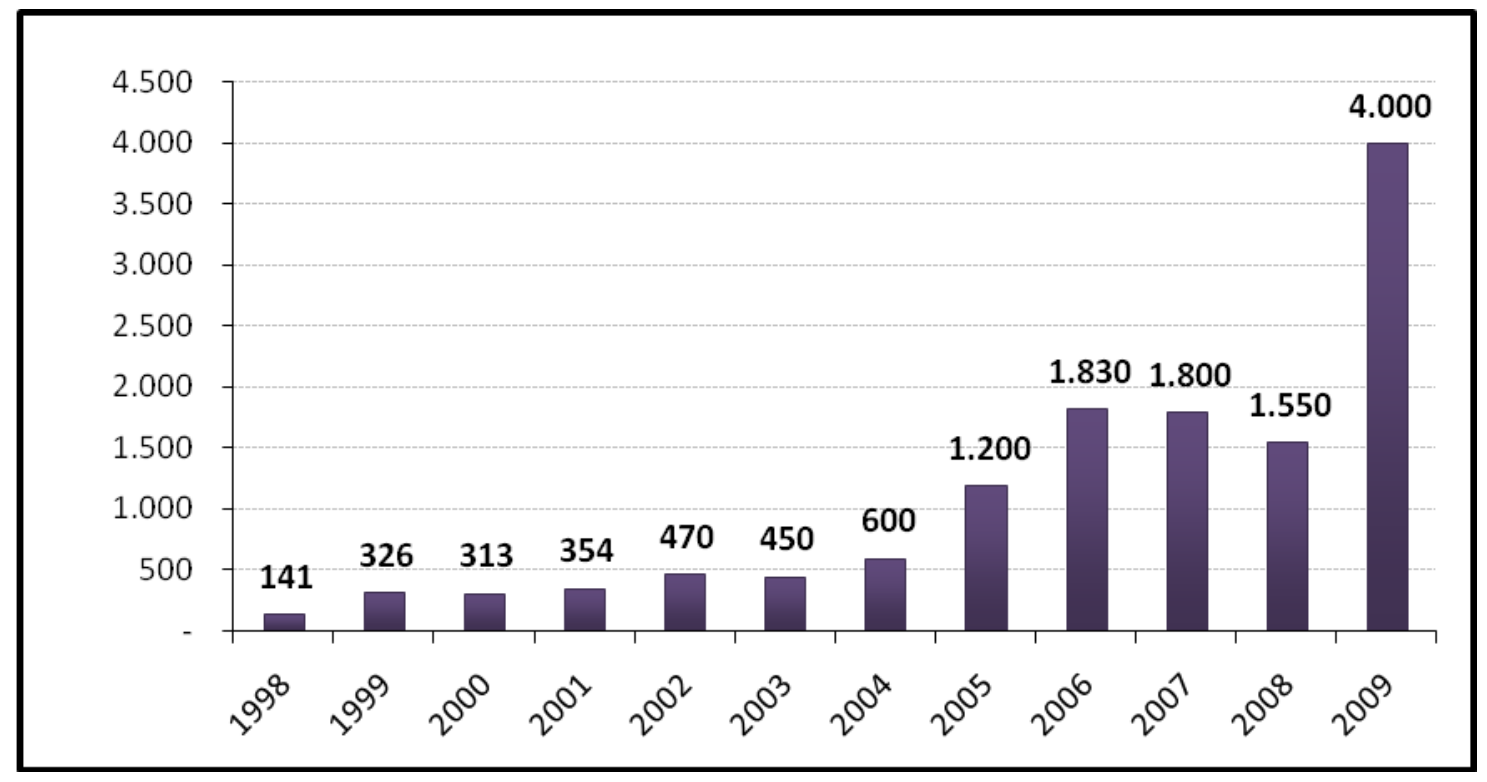

Fonte: Caixa Econômica Federal, 2009.

Apesar dos bons resultados do FGTS, observa-se que o mesmo não está ocorrendo para a remuneração das contas aplicadas junto ao fundo. A tabela 08 mostra que, com exceção dos anos de 2006 e 2007, na década de 2000 a remuneração das contas do fundo foi inferior ao índice IPCA.

Os números apresentados demonstram a importância na destinação dos recursos do FGTS para habitação, saneamento, infraestrutura e outros setores. Por outro lado, fica o trabalhador que contribui junto ao fundo com o ônus de financiar habitação, seja popular ou não, sem ao menos possuir seus recursos reajustados adequadamente. Esta talvez seja a maior imperfeição do sistema: a sociedade, por meio da parcela produtiva dos trabalhadores que têm conta no fundo, subsidia investimentos que deveriam ser da obrigação do estado e iniciativa privada. 
TABELA 08 - REMUNERAÇÃO DAS CONTAS

\begin{tabular}{|r|r|r|}
\hline ANO & TR + 3\% a.a. & \multicolumn{1}{c|}{ IPCA } \\
\hline 1995 & $35,57 \%$ & $22,41 \%$ \\
\hline 1996 & $12,87 \%$ & $9,56 \%$ \\
\hline 1997 & $13,08 \%$ & $5,22 \%$ \\
\hline 1998 & $11,03 \%$ & $1,66 \%$ \\
\hline 1999 & $8,90 \%$ & $8,94 \%$ \\
\hline 2000 & $5,16 \%$ & $5,97 \%$ \\
\hline 2001 & $5,35 \%$ & $7,67 \%$ \\
\hline 2002 & $5,89 \%$ & $12,53 \%$ \\
\hline 2003 & $7,79 \%$ & $9,30 \%$ \\
\hline 2004 & $4,87 \%$ & $7,60 \%$ \\
\hline 2005 & $5,62 \%$ & $5,69 \%$ \\
\hline 2006 & $5,10 \%$ & $3,14 \%$ \\
\hline 2007 & $4,49 \%$ & $4,46 \%$ \\
\hline 2008 & $4,68 \%$ & $5,90 \%$ \\
\hline 2009 & $2,66 \%$ & $2,97 \%$ \\
\hline ACUMULADO & $250,43 \%$ & $196,88 \%$ \\
\hline
\end{tabular}

Fonte: CEF, 2009

Analisando as contas ativas divididas por faixa de renda na tabela 09, observa-se que o FGTS exerce uma função social importante num país que convive com imensas desigualdades quanto ao acesso a crédito. A população com até um salário mínimo possui um saldo médio de $\mathrm{R} \$ 121,00$, representando 27,29\% dos contribuintes e 3,44\% do saldo do FGTS; já a população com renda acima de 150 salários mínimos possui saldo médio de $\mathrm{R} \$ 121.061,70$, representando $0,11 \%$ dos contribuintes e $14,56 \%$ dos recursos do fundo. Os dados demonstram claramente que a população que retém os maiores valores é minoria junto aos financiamentos concedidos pelo FGTS, que possui, sob esse aspecto, a função de complementar o financiamento de imóveis para a população de menor renda. 
TABELA 09 - SALDO DAS CONTAS ATIVAS POR FAIXA DE SM

\begin{tabular}{|l|r|r|r|r|r|}
\hline \multicolumn{1}{|c|}{ FAIXA SM } & QTDE. DE CONTAS & PART $\%$ & SALDO R $\$ M I$ & $\%$ & $\begin{array}{c}\text { SALDO MÉDIO } \\
\text { EMR } \$\end{array}$ \\
\hline ATÉ 1 SM & 47.533 .424 & $27,29 \%$ & 5.752 .741 & $3,44 \%$ & 121,00 \\
\hline DE 01 A 04 SM & 15.427 .129 & $8,85 \%$ & 15.257 .462 & $9,13 \%$ & 989,00 \\
\hline DE 04 A 06 SM & 3.751 .586 & $2,15 \%$ & 8.561 .621 & $5,12 \%$ & $2.282,10$ \\
\hline DE 06 A 10 SM & 3.925 .870 & $2,25 \%$ & 14.162 .678 & $8,47 \%$ & $3.607,50$ \\
\hline DE 10 A 15 SM & 2.989 .294 & $1,71 \%$ & 16.788 .808 & $10,04 \%$ & $5.616,30$ \\
\hline DE 15 A 20 SM & 1.286 .597 & $0,73 \%$ & 10.347 .256 & $6,19 \%$ & $8.042,30$ \\
\hline DE 20 A 30 SM & 1.543 .724 & $0,88 \%$ & 17.352 .208 & $10,38 \%$ & $11.240,40$ \\
\hline DE 30 A 40 SM & 668.510 & $0,38 \%$ & 10.728 .603 & $6,42 \%$ & $16.048,50$ \\
\hline DE 40 A 60 SM & 642.675 & $0,36 \%$ & 14.509 .725 & $8,68 \%$ & $22.577,00$ \\
\hline DE 60 A 100 SM & 483.459 & $0,27 \%$ & 17.173 .625 & $10,27 \%$ & $35.522,40$ \\
\hline DE 100 A 150 SM & 215.262 & $0,12 \%$ & 12.111 .738 & $7,24 \%$ & $56.265,00$ \\
\hline ACIMA DE 150 SM & 201.051 & $0,11 \%$ & 24.339 .581 & $14,56 \%$ & $120.061,70$ \\
\hline TOTAL & 78.668 .581 & & 167.086 .046 & & $2.123,92$ \\
\hline
\end{tabular}

Fonte: CEF, 2009

\subsection{POLÍTICAS DE GARANTIAS PARA HABITAÇÃO}

O Sistema de Financiamento Imobiliário (SFI) propiciou vários instrumentos importantes ao setor habitacional, como os sistemas de garantias.

Porém, é fato que os recursos captados no âmbito do SFI devem ser destinados a operações de mercado, sem subsídios, com base na livre negociação e, portanto, não se enquadram em soluções para a faixa de renda estudada neste trabalho. Sua importância está nas garantias, não na captação.

Nesta seção são abordadas as garantias existentes na legislação brasileira que permitem estabelecer uma relação de segurança tanto para o empreendedor quanto para o mutuário.

\subsubsection{ALIENAÇÃO FIDUCIÁRIA}

A falta de garantia real ao empreendedor sempre foi considerada um grande problema na legislação brasileira, responsável, em parte, pela deficiência do setor imobiliário. No final da década de 1990, muito se evoluiu em relação ao tema, sendo a garantia real um dos aspectos favoráveis ao aquecimento do setor nos últimos anos. 
Em 1997, com a aprovação da Lei $\mathrm{n}^{\circ}$ 9.514, que trata do sistema de financiamento imobiliário, muito se avançou nesse aspecto, uma vez que foi criada a Alienação Fiduciária, que é a cessão do direito creditório decorrente de contratos de alienação de imóveis financiados. Trata-se de um direito real que está dentro do direito de propriedade, fornecendo garantia.

A propriedade fiduciária é, pois, um direito real em coisa própria. Nessa modalidade, o credor toma o próprio bem em garantia, de forma que o comprador fica impedido de negociálo a terceiros, ficando o direito de propriedade transferido do devedor ao credor até a quitação do financiamento.

No passado, a inexistência desse recurso dificultava a retomada do bem, e o processo para isso chegava e demorar oito anos ou mais. Quando acontecia, era acompanhada de dívidas de IPTU (Imposto Predial e Territorial Urbano) e condôminos, gerando prejuízos aos empreendedores/ investidores. Após 1997, o sistema de recuperação do imóvel vem ocorrendo de forma mais eficiente, sendo recolocado mais rapidamente no mercado.

FIGURA 05 - FLUXOGRAMA DE FUNCIONAMENTO DA ALIENAÇÃO FIDUCIÁRIA 


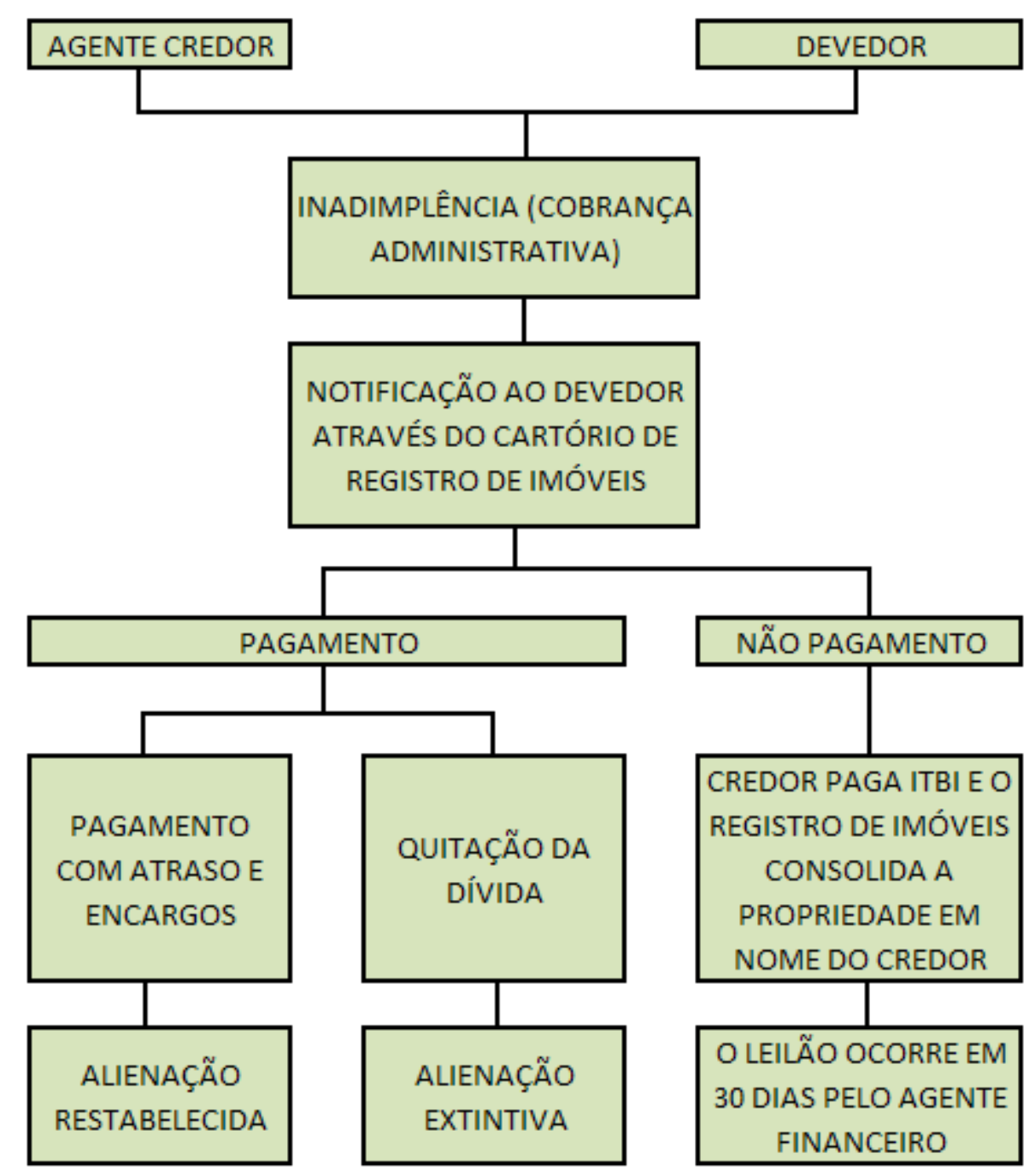

Fonte: Elaborado pela autora.

\subsubsection{PATRIMÔNIO DE AFETAÇÃO}

Criado por meio da Medida Provisória n².221 de 04/09/2001, o Patrimônio de Afetação veio garantir a continuidade das incorporações imobiliárias, em proteção dos aderentes lesados ao longo das quebras empresariais do setor (Moraes, 2008).

Após essa Medida Provisória, as dívidas de natureza tributária, trabalhista bem como as instituições financeiras ficam restritas ao empreendimento, não tendo qualquer relação com outros compromissos e dívidas da empresa. Desta forma, as receitas oriundas da incorporação ficam vinculadas somente para esse empreendimento, sem a possibilidade de desvio para 
outro negócio da empresa. Trata-se de uma medida importante, por estabelecer uma garantia aos compradores de unidades habitacionais em relação à entrega do imóvel.

\subsection{A QUESTÃO TRIBUTÁRIA DO FINANCIAMENTO À HABITAÇÃO POPULAR}

São vários os pontos importantes na questão tributária brasileira, principalmente em relação ao planejamento tributário de um empreendimento. A atividade é muito pulverizada, o que, de um lado, é positivo, por gerar competitividade, mas, de outro, dificulta o levantamento de dados necessários à elaboração de estatísticas sobre o setor.

Os tributos se iniciam quando da aquisição de uma gleba, sendo que a empresa em geral investe capital próprio para comprar o terreno. Vários são os tributos gerados nessa operação, como por exemplo, o ITBI (Imposto sobre a Transmissão de Bens Imóveis), que possui uma alíquota que varia de 2 a $6 \%$. Os impostos sobre a renda na transação e outros encargos dificultam o levantamento do conjunto total de tributações existentes, além de aumentar o preço do terreno, levando também a aumentos na cadeia da produção imobiliária.

Outro exemplo é em relação ao ICMS (Imposto sobre Circulação de Mercadorias e Serviços), pois existe uma diferenciação de alíquotas desse imposto entre os diversos tipos de materiais empregados na construção civil.

A saída para as grandes empresas que efetuam um planejamento tributário é tentar empregar bem todos os dispositivos oferecidos pela lei para a redução dos impostos.

A partir de 2004, por meio da Lei $\mathrm{n}^{\circ} 10.931$, foi criado o Regime Especial Tributário (RET), que tem caráter opcional e irretratável enquanto perdurarem os direitos de crédito ou obrigações do incorporador junto aos mutuários dos imóveis que compõem a incorporação. Por meio dessa lei, criou-se um sistema de tributação unificado para o setor de incorporações imobiliárias.

Desta forma, o IRPJ (Imposto de Renda Pessoa Jurídica), o CSSL (Contribuição Social Sobre o Lucro Líquido), COFINS (Contribuição para o Financiamento da Seguridade Social) e o PIS/PASEP (Programas de Interação Social/ Formação do Patrimônio do Servidor Público) são realizados por meio do recolhimento de alíquota única equivalente a $6 \%$, aplicados sobre a receita mensal recebida. Trata-se de um regime válido somente para as incorporações imobiliárias, operações envolvendo a construção, assim como para a comercialização de imóveis constituídos de várias unidades autônomas que, conjuntamente, formarão um condomínio. 


\subsection{ANÁLISE DE MECANISMOS DE POLÍTICA DE CRÉDITOS PARA O BRASIL}

Nos últimos anos, o Brasil atravessou o seu melhor momento econômico em relação às três últimas décadas. Vários foram os motivos: estabilidade econômica, expansão da renda e do consumo, investimentos crescentes, além da redução das desigualdades sociais. Um marco importante foi o alcance à condição de grau de investimento atribuída pelas agências de classificação de risco. Houve uma mudança significativa, impactando positivamente no setor da construção civil e na expansão do crédito imobiliário.

A concessão de crédito aumentou consideravelmente, porém os critérios adotados para tal necessitam de aperfeiçoamentos.

Para Rossbach (2005), vários são os problemas característicos de mercados emergentes para financiar imóveis; entre eles, destacam-se:

$\checkmark$ Predominância de imóveis em situação irregular, inviabilizando sua utilização como garantia hipotecária;

$\checkmark$ Inexistência de sistemas eficientes de avaliação do imóvel para garantia do empréstimo;

$\checkmark$ Processos longos e custosos de execução de garantias;

$\checkmark$ Capacidade de pagamento das famílias;

$\checkmark$ Taxas de juros elevadas.

Várias mudanças estruturais ocorreram no país a partir do início da década de 2000, sendo atualmente observadas diferenças em relação ao quadro apontado por Rossbach (2005) e que favoreceram o aquecimento do setor habitacional brasileiro: a economia já se encontra em patamares estáveis, permitindo uma acentuação da capacidade de produção e aquisição de produtos imobiliários; houve redução da taxa de juros e maior oferta de crédito, tanto para os compradores de imóveis quanto para as incorporadoras e construtoras, além de um arcabouço legal propiciando processos de garantia mais elaborados.

Porém, apesar do quadro atual apontar para uma situação favorável, ainda é possível identificar a falta de alguns mecanismos que poderiam propiciar alterações mais profundas no quadro habitacional brasileiro.

No Chile, por exemplo, na década de 1970, houve uma reestruturação na política habitacional, com resultados satisfatórios, uma vez que o país supera anualmente os níveis mínimos necessários para suprir o crescimento demográfico (ROJAS, 2001). 
O Chile tanto conseguiu desenvolver ações para mitigar o déficit habitacional das classes de renda mais baixa como desenvolver um sistema de livre mercado para atender às classes de renda média e baixa (RODRIGUES, 2009).

Para Carneiro e Valpassos (2003), a principal característica do modelo chileno é a ampla distinção entre financiamentos às diversas classes sociais do país. As políticas vão desde subsídios públicos voltados para a classe de renda mais baixa até sistema de financiamento imobiliário privado fundamentado na emissão de títulos lastreados em hipotecas em três formatos: letras hipotecárias, hipotecas endossáveis ou leasing com opção de compra.

O modelo chileno foi implantado num cenário muito semelhante ao brasileiro: estabilidade econômica, baixa inflação, além de pouca volatilidade da taxa de câmbio.

Já nos Estados Unidos, Carneiro e Valpassos (2003) acreditam que as políticas adotadas servem como base para identificar como funciona um sistema de financiamento imobiliário integrado ao mercado de capitais.

Green e Watcher (2005) ressaltam que, principalmente na década de 80, a securitização garantiu um crescimento da relação entre dívida hipotecária e Produto Interno Bruto americano. Para os autores, a atuação do governo americano no financiamento imobiliário foi decisiva, e se deu por meio de agências governamentais que exerciam como funções principais:

$\checkmark$ Promoção de seguros contra inadimplência;

$\checkmark$ Promoção de diversos tipos de ativos lastreados em hipotecas;

$\checkmark$ Provimento de liquidez para o mercado por meio da compra de empréstimos hipotecários;

$\checkmark$ Subsídio aos financiamentos habitacionais para a baixa renda

Essas ações, de ordem federal e estadual, geraram condições para um bom funcionamento do mercado imobiliário americano. Como destacado por Rodrigues (2009), uma das ações de grande relevância na esfera federal foi a criação de um subsídio para a concessão de um seguro contra inadimplência, que chega a cobrir $100 \%$ do principal e pode ser financiado em 30 anos. No caso dos estados, esse subsídio acontece principalmente por meio da isenção fiscal sobre os ganhos em títulos lastreados em hipotecas.

Entre as décadas de 1940 e 1970, o sistema de financiamento habitacional americano baseou-se predominantemente nos depósitos de poupança, proporcionando às instituições financeiras acesso a recursos relativamente baratos. O declínio da importância desse sistema 
iniciou-se na década de 1980, pois existiam regulamentações que impunham um limite para os depósitos de poupança, além do excessivo aumento das taxas de juros nominais do final da década de 1970, provocando um descasamento entre passivos e ativos das instituições de crédito. Tais medidas acabaram por causar um amadurecimento do mercado secundário de hipotecas, atraindo assim investidores novos e recursos financeiros (ROSSBACH, 2005).

Muitas dessas ações podem servir de modelos para o Brasil. Apesar de todos os problemas que ocorreram no SFH, analisados neste trabalho, como destaca a FGV (2007), nos primeiros 15 anos de operação, a participação dos saldos de financiamentos habitacionais para o setor privado, no que se refere aos empréstimos bancários públicos e privados, saltou de $2 \%$ a $20 \%$.

Esse desempenho, contudo, não foi acompanhado pelo atendimento da população de baixa renda. De fato, os números de unidades concedidas para a classe de renda de até cinco salários mínimos foram irrisórios, se comparados ao total contratado pelo SFH. 


\section{O PROGRAMA MEXICANO}

A experiência mexicana é muito interessante para o Brasil devido às semelhanças históricas entre os dois países. Assim como o Brasil, o México experimentou perdas de bancos na década de 1970 e período de alta inflação na década de 1980; além disso, instituiu a amortização negativa da dívida habitacional, dado que as parcelas eram reajustadas de acordo com os salários. Outras semelhanças referem-se à falta de informação em relação aos tomadores, retomada custosa do imóvel, falta de padronização nos contratos, dificultando as securitizações (ESPINOSA e ZANFORLIN, 2008).

A extensão territorial do México corresponde a mais ou menos a quarta parte do território brasileiro. Ao norte, o país faz fronteira com os Estados Unidos, e isto é da mais alta relevância em termos econômicos. As três maiores cidades mexicanas são a Cidade do México (a maior do país, com aproximadamente 20 milhões de habitantes), Guadalajara (centro comercial) e Monterrey (centro industrial), conforme figura 06.

\section{FIGURA 06 - O MÉXICO E A LOCALIZAÇÃO DE SEUS PRINCIPAIS CENTROS}

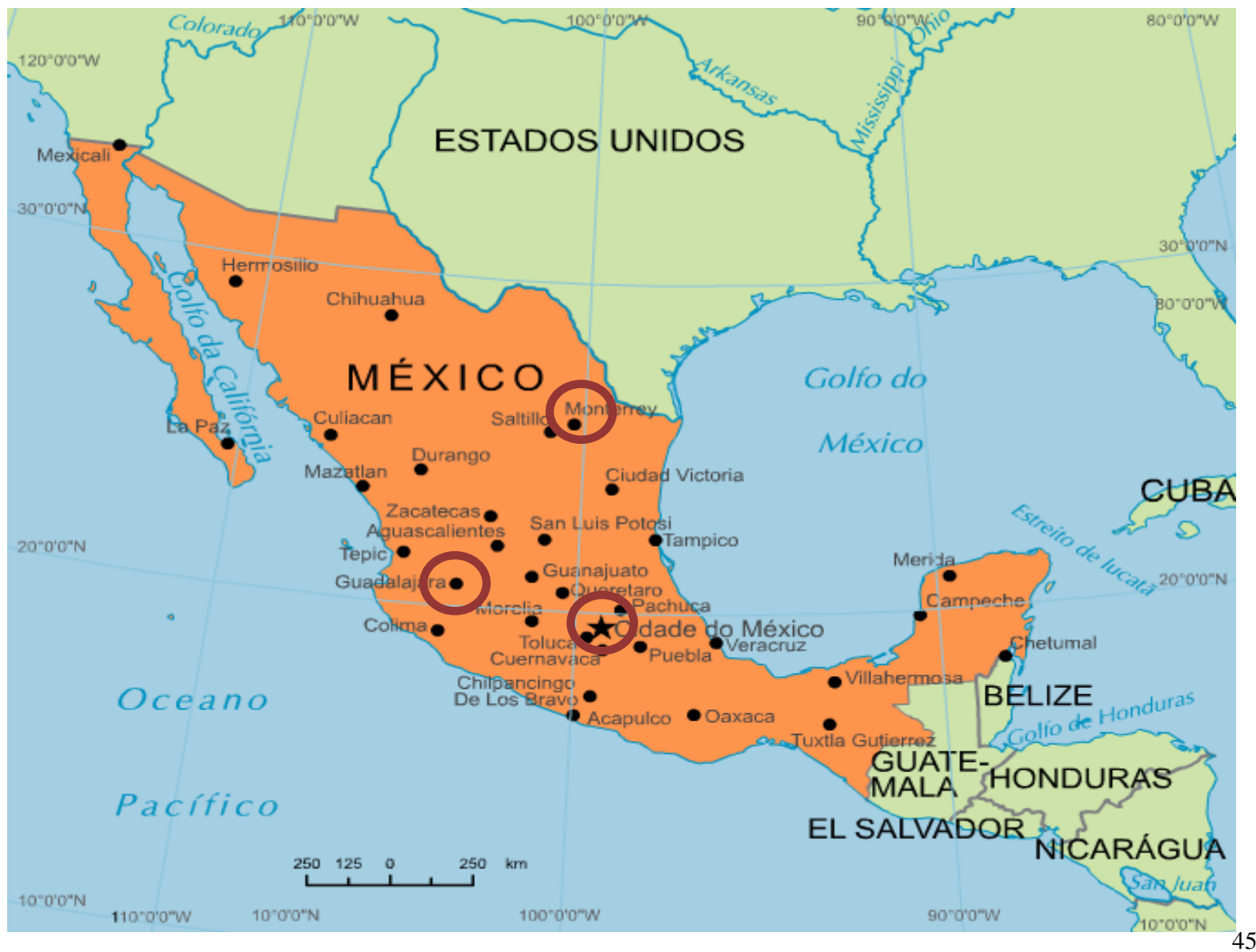




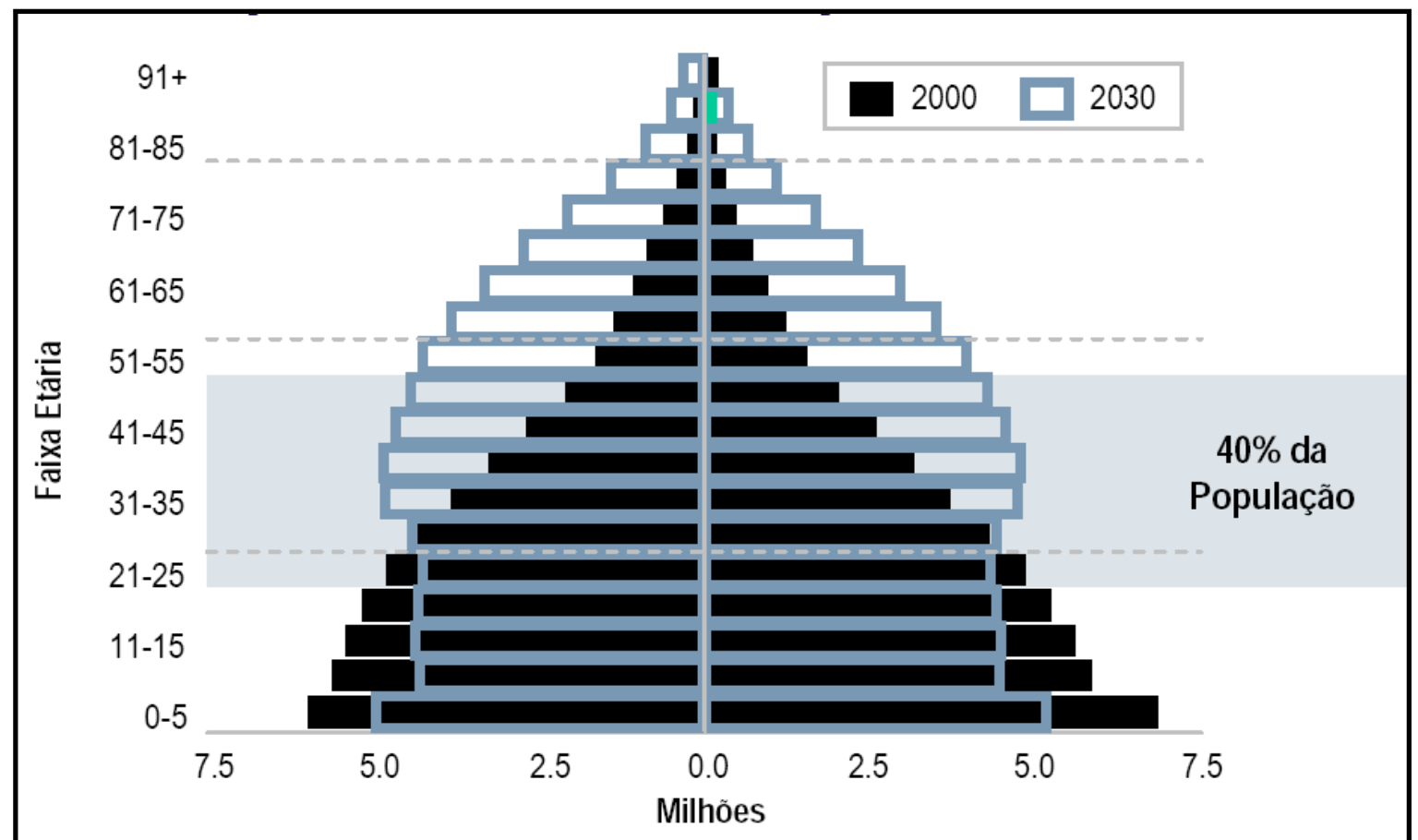

Fonte: Conavi, Su Casita apud Parkinson, 2006

Analisando o gráfico 15, observa-se que, para os próximos vinte anos, $40 \%$ da população terá entre 30 e 45 anos, faixa etária mais propensa a adquirir novos domicílios.

Segundo Barreda (2007), em 2003, os mexicanos que trabalhavam nos Estados Unidos enviaram aproximadamente U\$ 14 bilhões ao México. A grande maioria dessas pessoas pretende voltar ao país e adquirir um imóvel para suas famílias, constituindo um corpo considerável de potenciais compradores.

Tendo em vista que o presente estudo, além das políticas públicas voltadas ao setor da habitação, deve considerar as condições econômicas de cada país, Brasil e México, torna-se necessário fazer uma comparação entre ambos no que se refere ao poder de compra dos salários. Para tanto, referenciou-se o salário mínimo, considerando o custo de vida de cada país para indicar seu real poder de compra, não se convertendo os valores, portanto, a uma moeda comum, como o dólar.

De acordo com esse critério, o Brasil apresenta um salário mínimo com poder de compra maior que o do México. 


\section{GRÁFICO 16 - PODER DE COMPRA DO SALÁRIO MÍNIMO}

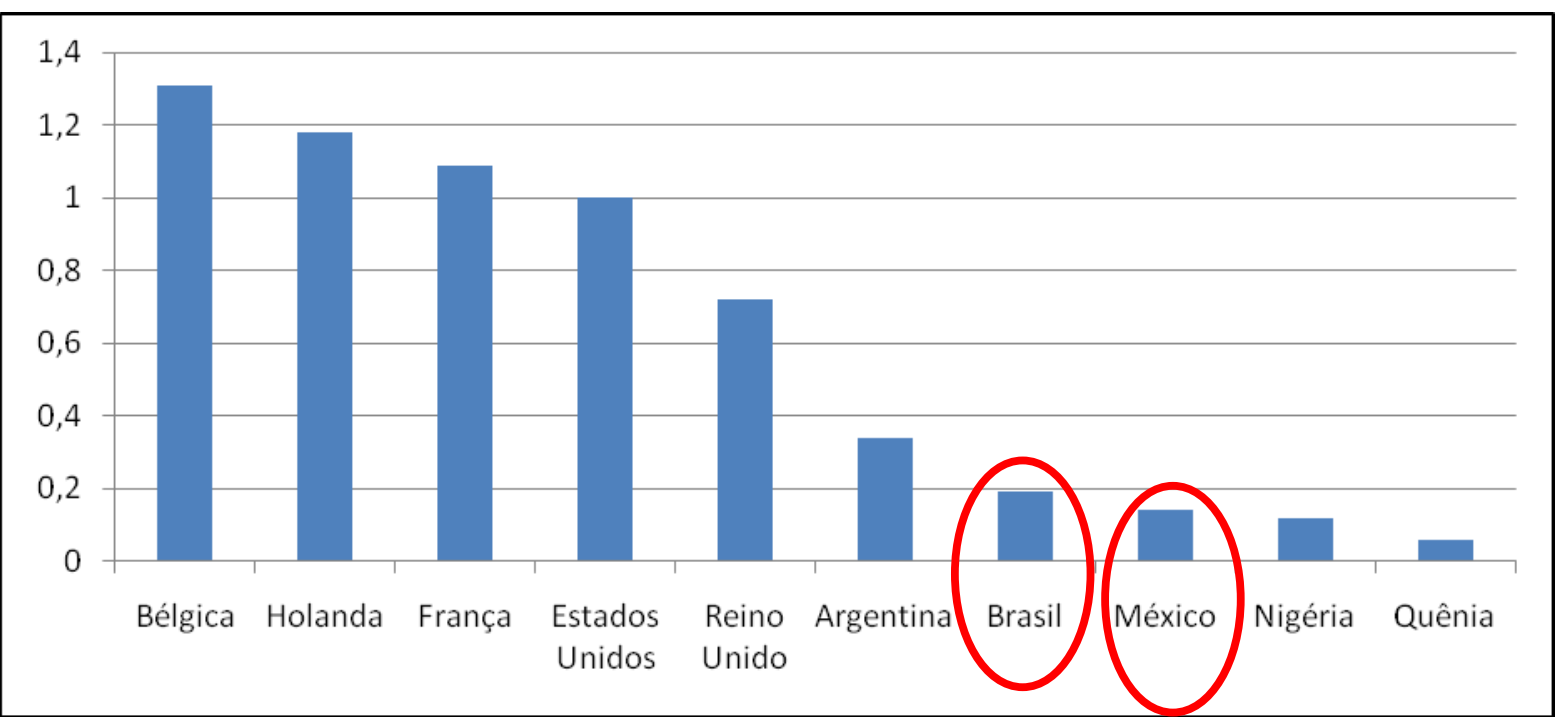

Fonte: Organização Internacional do Trabalho e do Banco Mundial relativos ao ano 2000.

Na década de 1960, juntamente com o processo de industrialização, o poder público mexicano instituiu algumas políticas habitacionais. Em 1963, o Banco do México criou o Fundo de Operação e Financiamento Bancário à Moradia (Fovi), cuja principal atribuição era promover a construção e melhoria das moradias de interesse social, além de conceder crédito por meio de bancos privados. Em 1972, em uma reforma constitucional, os empresários passaram a ser obrigados a aportar recursos para a constituição de um Fundo Nacional de Moradia e estabelecer um sistema de financiamento capaz de oferecer crédito para a compra de moradia por seus empregados. Desta forma, nasce o Fundo Nacional da Moradia para os Trabalhadores (INFONAVIT). Trata-se, basicamente, de um fundo habitacional compulsório dos trabalhadores privados que funciona de maneira semelhante ao Fundo de Garantia por Tempo de Serviço (FGTS) brasileiro, tema tratado no item 3.3 deste estudo.

Até o início da década de 1980, a política habitacional havia sido exclusivamente realizada por intervenção direta do Estado, tanto na construção como no financiamento, outorgando subsídios indiretos, com taxas de juros reduzidas.

Apenas nos anos 90 teve início a consolidação das instituições de moradia nacionais em agentes financeiros. Desde então, a política habitacional mexicana ocupou lugar de destaque nos planos nacionais de desenvolvimento, com o estabelecimento de linhas de reforma das instituições responsáveis pela política, bem como um esforço de seleção da população a ser atendida. 
O México priorizou o setor habitacional nos últimos anos, conquistando avanços significativos, principalmente se considerarmos a crise financeira atravessada pelo país na década de 1990, mais precisamente nos anos de 1994 e 1995, e que levou à falência o sistema bancário.

Para fazer frente ao atraso do setor habitacional, foi colocado em prática, a partir de 2001, um programa habitacional estratégico, com dois princípios básicos: primeiramente organizar e ampliar a oferta de crédito e em seguida projetar a ocupação do solo e a infraestrutura necessária para buscar a redução dos custos de produção das moradias.

O objetivo principal da política habitacional mexicana é combinar subsídio, crédito de longo prazo e poupança própria das famílias, considerando sua capacidade de pagamento.

A seguir, são apresentados os modelos de financiamentos utilizados no México, principalmente aqueles voltados à população de baixa renda, buscando-se, posteriormente, apontar as diferenças e semelhanças em relação ao Brasil e avaliar a possibilidade de adoção de soluções semelhantes para a realidade brasileira.

\subsection{PRINCÍPIOS E TENDÊNCIAS DO MERCADO HABITACIONAL MEXICANO}

A partir do final da década de 1990, o México instituiu políticas habitacionais que alteraram a história do país. O governo atual vem conferindo perspectivas bem sucedidas no setor da habitação, uma prioridade em sua gestão, empenhando-se fortemente para atingir a meta de conceder um milhão de créditos habitacionais ao ano, durante os próximos seis anos de mandato.

Os resultados recentes da política habitacional no México indicam que se trata de uma meta possível. Na última década, o crédito habitacional cresceu, em média, 16,90\% ao ano, conforme cálculo da FGV, e em 2006 foram concedidos 725 mil empréstimos para moradias.

Ao longo do tempo, foram realizadas reformas que simplificaram a sistemática de concessão de crédito para as pessoas que têm emprego formal. Além disso, foi criado um mercado de hipotecas que dá liquidez ao sistema. Um dos grandes desafios no momento é tornar acessível a um maior número de pessoas a maneira para aquisição da casa própria baseada em subsídio, poupança própria e crédito de longo prazo. O público alvo nessa nova etapa é formado, preferencialmente, pelas famílias mais pobres, cuja renda vem do mercado informal de trabalho. 
No plano institucional, uma série de mudanças deu base para o desenvolvimento habitacional em curso. A primeira delas ocorreu há quinze anos e possibilitou modificar o dispositivo referente à propriedade das terras. A Revolução Mexicana de 1910 determinou a posse da terra pelos camponeses que nela trabalhassem. Essa figura jurídica de usufruto inviabilizava a transação de propriedades. A mudança da legislação no início dos anos 1990 permitiu a venda das terras, desde que houvesse acordo entre o grupo de camponeses detentores da posse. Apesar de ter sido um processo lento de transferência de propriedade, essa mudança institucional possibilitou a oferta de terrenos para construção de conjuntos habitacionais fora das cidades.

Outro fator importante foi a reforma previdenciária, que direcionou a contribuição dos cidadãos para fundos de pensão privados. Reformas da legislação simplificaram a transação de hipotecas, eliminando vários requisitos burocráticos, e paralelamente, mudanças legais possibilitaram tornar mais eficiente a recuperação de garantias em caso de não pagamento das prestações.

O sucesso mexicano está baseado, primeiramente, na estabilidade econômica. Neste século, as taxas de juros e a inflação caíram de forma significativa, ainda que o crescimento econômico (de 3,50\% ao ano nos últimos dez anos), como no caso brasileiro, não tenha sido o desejado. Um bom indicador do período foi a queda da taxa real de juros sobre créditos hipotecários, que passou de um patamar de cerca de 30\% ao ano, em 2000, para 10\% em 2007 (CONSTRUÇÃO MERCADO, 2007).

\subsection{A IMPORTÂNCIA DOS ÓRGÃOS PÚBLICOS E DA INICIATIVA PRIVADA}

Historicamente vem sendo discutida a necessidade de uma administração pública moderna e eficiente no México. Em determinados períodos, diante do colapso de um modelo mais rígido de administração, surgem alguns defensores da modernização do aparelho estatal, apelando pela descentralização, autonomia e liberdade de operação por parte das organizações públicas. Algum tempo depois, o mesmo sistema acaba por resultar na criação de privilégios corporativistas, favorecimento, clientelismo e corrupção. 
No México, a política habitacional havia sido exclusivamente realizada por intervenção do estado, tanto na construção como no financiamento e outorga de subsídios indiretos, com taxas de juros reduzidas. (Abecip, 2007).

No Brasil, e na maior parte dos países em fase de desenvolvimento, a nova gestão pública foi sendo implementada, mesmo que em ritmos diferentes, por meio de algumas reformas no aparato estatal.

A descentralização de serviços públicos foi impulsionada, também, pela pressão em reduzir o déficit orçamentário e o nível de endividamento, buscando por fórmulas de gestão alternativas com mais flexibilidade e incremento do controle sobre a atividade, pelas entidades públicas.

\subsection{OS FUNDOS DE GARANTIA NO FINANCIAMENTO HABITACIONAL MEXICANO}

No México, tanto na década de 1960 quanto na década de 1970 foram criadas instituições específicas voltadas à política habitacional. Em 1963, o Fundo de Operação e Financiamento Bancário à Moradia (FOVI), e em 1972, o Instituto del Fondo Nacional de La Vivenda para los Trabajadores (INFONAVIT).

O Infonavit nada mais é do que um fundo habitacional compulsório dos trabalhadores privados, sendo que cada um deles possui uma conta individual, na qual é feito quinzenalmente um aporte pelo seu empregador equivalente a 5\% de seu salário com teto de 25 salários mínimos, o desconto é feito bimestralmente, e a concessão dos créditos se baseia em salários mínimos. Sua estrutura é muito semelhante ao FGTS, cujo aporte feito mensalmente é de $8 \%$ do salário. A principal diferença entre eles é que no México o Infonavit só oferece crédito aos seus contribuintes.

Em 2002, o Infonavit passou a financiar também imóveis usados, estimulando o mercado secundário. Em 2007 o Infonavit contava com 15 milhões de afiliados, pessoas que aportam para o instituto, com a concessão de crédito variandoentre U\$15 a U\$50 mil.

Para Vedrossi (2007, p.03), 
Um fator fundamental na formação do INFONAVIT é de que o mesmo se trata de um instituto com administração tripartite, Estado, iniciativa privada $e$ trabalhadores, o que leva a uma maior estabilidade de suas políticas de longo prazo, independente da vontade única do governo mexicano e influências políticopartidárias.

A modernização desses fundos impulsionou os bons resultados do sistema. Em 2006, do total da carteira hipotecária, 62\% eram referentes ao INFONAVIT (SOFTEC, 2007). Sua estrutura permite agilidade na concessão de crédito, mas, para tanto, foi necessário um processo de modernização e racionalização da instituição, afastando-a de orientações historicamente clientelistas. O sentido da reforma foi oferecer a uma instituição pública níveis de rentabilidade e eficiência de uma empresa privada.

As taxas de juros de empréstimos do INFONAVIT são menores que as de mercado e diferenciadas por classe de renda, o mesmo ocorrendo no sistema denominado FOVI. Ambos cobram seus mutuários por meio de desconto direto em folha de pagamento, diminuindo assim os custos do processo e limitando os problemas com inadimplência.

Tendo em vista o crescimento na liberação de crédito por parte do INFONAVIT, com uma concessão de mais de 450.000 em 2006 (Conavi, 2006), o fundo emitiu no mesmo ano uma operação de securitização de créditos imobiliários com o objetivo de captar recursos financeiros por meio do mercado de capitais.

A tabela a seguir mostra as diferenças relevantes entre as estruturas dos fundos hipotecários mexicanos.

\section{TABELA 10 - DIFERENÇA ENTRE OS DOIS SISTEMAS MEXICANOS: FOVI/ INFONAVIT}

\begin{tabular}{|l|c|c|}
\cline { 2 - 3 } \multicolumn{1}{c|}{} & FOVI & INFONAVIT \\
\hline ANO DE FUNDAÇÃO & 1963 & 1972 \\
\hline FONTES DE FINANCIAMENTO & $\begin{array}{c}\text { CARTEIRA PRÓPRIA/ BANCO } \\
\text { MUNDIAL/ ORÇAMENTO FEDERAL/ } \\
\text { FUNDOS PENSÃO }\end{array}$ & DESCONTO DE 5\% DO SALÁRIO \\
\hline DISTRIBUIÇÃO & SOFOLES & DIRETO \\
\hline RENDA FAMILIAR & 04 A 10 SM & 03 A05 SM \\
\hline INDEXAÇÃO & MENSAL PELA UDI'S & - \\
\hline VALOR DO EMPRÉSTIMO & ATÉ 90\% DO PREÇO & $100 \%$ DO PREÇO \\
\hline VALOR DAS UNIDADES & ENTRE U\$9.000 E U $\$ 15.000$ & - \\
\hline PRAZO & 30 ANOS & 30 ANOS \\
\hline
\end{tabular}

Fonte: Adaptado de Pincherle 
Na ocasião em que foi criado o INFONAVIT (década de 1970), com o mesmo objetivo, mas voltado aos trabalhadores do setor público, foi instituído o Fondo de la Vivencia Del Issste (Fovissste). Porém, este não conseguiu repetir os mesmos resultados em relação ao volume de créditos concedidos.

\section{FIGURA 07 - FLUXOGRAMA DO FUNCIONAMENTO DO FOVISSSTE}

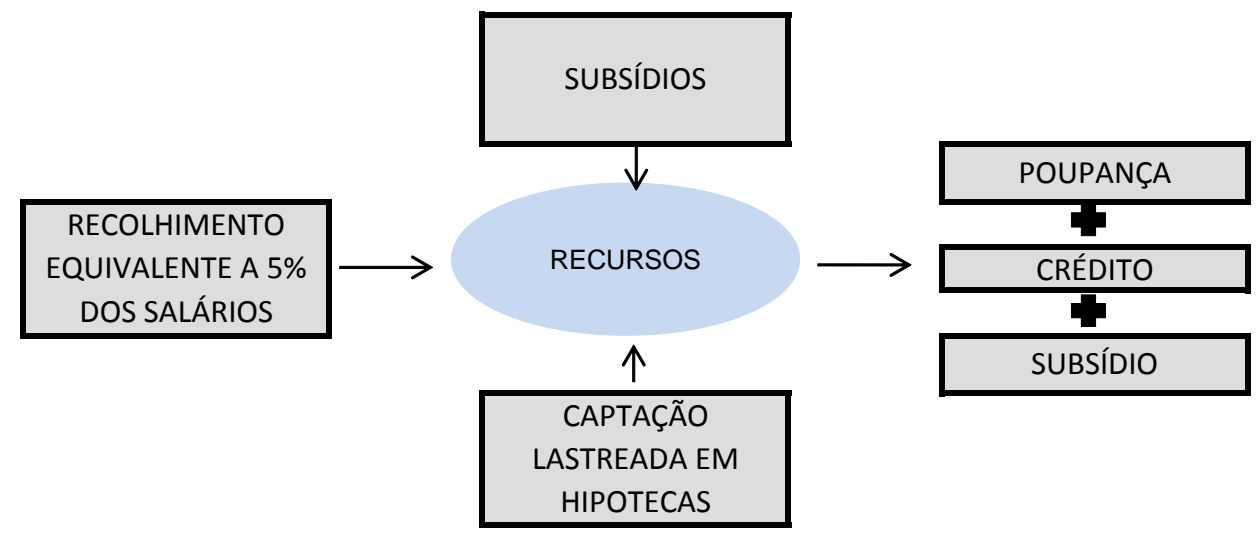

Fonte: Sinduscon e FGV Projetos (2007).

Em 1994, segundo Moraes (2008), ocorreu uma das maiores crises já enfrentadas pelo mercado mexicano. Mais da metade da concessão dos financiamentos habitacionais era garantida pelas instituições financeiras, especificamente, pelos bancos comerciais. Desta forma, o governo se viu obrigado a assumir parte importante dos créditos em liquidação, tornando-se acionista das instituições.

Conforme citado anteriormente, foi criada em 1963, com a denominação de FOVI, uma instituição financeira governamental com o objetivo principal de oferecer crédito imobiliário à população de baixa e média renda. Em 2001, sua denominação foi alterada para Sociedade Hipotecária Federal (SHF), renovando-se seu objetivo principal e criando os mercados primário e secundário de hipotecas. Trata-se de uma das peças chaves do modelo mexicano. Em sua concepção, a entidade conta com a ajuda de recursos governamentais, em especial com os aportes para formar seu capital.

Pelo fato de ser uma agência governamental, a SHF tem a garantia de crédito do governo mexicano e capta recursos financeiros junto ao mercado de capitais, operações de crédito junto ao Banco Mundial e recursos públicos. 
A SHF origina créditos imobiliários para a aquisição residencial por meio das Sociedades Financeiras de Objeto Limitado (Sofoles), que oferecem garantias, mas não fornecem crédito diretamente ao mutuário final. Em sua estrutura, é possível que viabilizem créditos em UDIs ${ }^{5}$, moeda indexada à inflação, tendo como referência o salário mínimo, o que, para Lipscomb; Harvey e Hunt (2003), é uma alternativa eficiente para originar créditos de longo prazo.

As Sofoles atendem a um segmento de população de média e baixa renda, pertencente principalmente ao mercado informal, embora também atendam ao mercado formal, oferecendo créditos de U\$50 a U\$300 mil.

Também em 2001, foi criado um amplo programa habitacional voltado às famílias em estado de pobreza extrema e àquelas que recebem até três salários mínimos. Com relação a esse público alvo, o governo possuía dois intuitos inicialmente:

$1^{\circ}$ Ampliar a oferta de crédito,

$2^{\circ}$ Organizar a ocupação do solo e infraestrutura necessária.

Para ampliar a oferta ao crédito, dando subsídio direto à população de baixa renda para a aquisição de unidade habitacional, o programa adquiriu algumas formas: terrenos pertencentes à municipalidade, onde se faz necessário um aporte por parte do governo federal, ou pertencente aos beneficiários, onde o governo local entra com a infraestrutura urbana, projetos e bases institucionais e técnicas para a edificação da unidade habitacional (FGV, 2007).

Conforme Moraes (2008), em 2003, os bancos retornam ao mercado de financiamento hipotecário e, em 2005, junto às demais instituições financeiras, passam a ser responsáveis pela concessão de $17 \%$ do crédito oferecido.

Ainda para o mesmo autor, assim como no Brasil, a dinâmica demográfica gerou uma demanda por moradia no México. Em 2000, o déficit habitacional mexicano era estimado em 5,6 milhões de unidades habitacionais; em 2007, este número era de 6,5 milhões (Sinduscon, 2007). Em apenas um ano (2006) o sistema mexicano foi capaz de produzir 680 mil moradias para a baixa renda, dando assim mostra dos resultados das políticas até então implementadas.

A figura 08 apresenta de forma resumida as ações mexicanas ao longo dos últimos 40 anos para o setor habitacional:

\footnotetext{
${ }^{5}$ Unidad de Inversión. Moeda publicada pelo Banco México e que reflete a variação do INPC - Índice Nacional de Preço ao Consumidor (Banco México, 2009).
} 


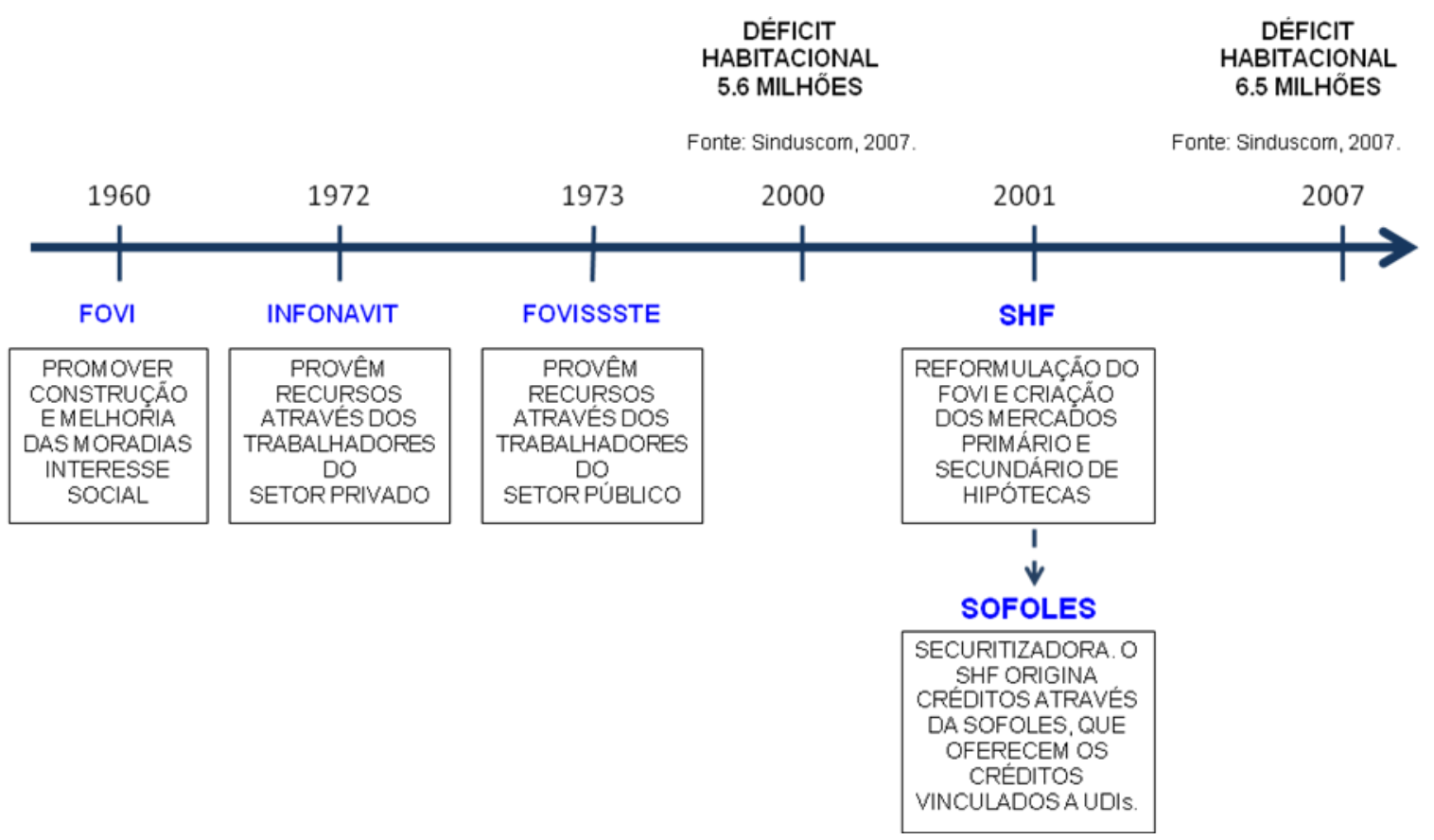

Fonte: Elaborado pela autora.

O mercado mexicano conseguiu mudar o quadro de insolvência generalizada nos anos 1990. Os devedores em atraso acabavam sendo premiados com facilidades para acertar seus débitos, o que fez com que bons clientes se transformassem em maus pagadores. Houve, então, uma mudança nos mecanismos de financiamentos e nos seus incentivos, sendo que aqueles que não atrasavam as prestações poderiam ter uma queda de 0,5 ponto percentual ao ano na taxa de juros, chegando a acumular até três pontos percentuais em seis anos. Trata-se de algo significativo, pois, assim, as taxas caem de $12 \%$ para $9 \%$ ao ano (BARREDA, 2007).

Foram então aplicadas com êxito medidas que ajudaram a construir um sistema em que o cidadão de baixa renda participa e escolhe sua moradia, fugindo de esquemas paternalistas em que o Estado determina onde e como o trabalhador mais pobre vai morar.

Na tabela 11 estão os segmentos de mercado em que o México atua e suas principais características. Vale ressaltar que o segmento denominado "mínimo" é atendido pelo governo mexicano por meio de políticas sociais; já os segmentos "social” e "econômico" são atendidos por meio de soluções que podem ou não ter a participação do governo. 
TABELA 11 - SEGMENTOS DE MERCADO EM QUE O MÉXICO ATUA E SUAS PRINCIPAIS CARACTERÍSTICAS

\begin{tabular}{|l|c|c|c|}
\hline \multicolumn{1}{|c|}{ SEGMENTO } & $\begin{array}{c}\text { FAIXA DE PREÇO DA } \\
\text { MORADIA }\end{array}$ & ÁREA (M2) & CARACTERÍSTICAS \\
\hline MÍNIMO & ABAIXO DE U $\$ 7.000$ & 30 & $\begin{array}{c}\text { 1 OU 2 CÔMODOS/ INFRA-ESTRUTURA } \\
\text { PRECÁRIA AUTO-CONSTRUÇÃO }\end{array}$ \\
\hline SOCIAL & DE U $\$ 7.000$ A U $\$ 18.000$ & 45 & $\begin{array}{c}\text { COZINHA SALA 1 OU 2 DORM./ 1 BANHEIRO/ 1 } \\
\text { VAGA INFRA-ESTRUTURA COMPLETA }\end{array}$ \\
\hline ECONÔMICO & DE U $\$ 18.000$ A U $\$ 34.000$ & 40 & $\begin{array}{c}\text { COZINHA SALA 2 DORM./ 1 BANHEIRO/ } 1 \\
\text { VAGA INFRA-ESTRUTURA COMPLETA }\end{array}$ \\
\hline
\end{tabular}

Fonte: Vedrossi, 2007 - adaptado.

Essa expansão do crédito foi responsável por $12 \%$ do crescimento econômico nacional nesses dez anos. Combinando subsídio com crédito de longo prazo e valorizando a poupança própria, é uma referência valiosa para as políticas habitacionais de países emergentes como o Brasil (BARREDA, 2007).

\subsection{A PRINCIPAL FONTE DE RECURSOS PARA HABITAÇÃO POPULAR NO MÉXICO: O INFONAVIT}

Com mais de 30 anos de funcionamento, o INFONAVIT desenvolveu capacidade de organização e administração próprias. Primeiramente realizava a aquisição de terrenos, contratava e supervisionava a implantação de edifícios, desenvolvia os projetos arquitetônicos, contratava a obra das unidades habitacionais e, finalmente, as financiava.

A atribuição de habitação e de crédito era feita formalmente por meio de sorteios; contudo a função hipotecária do INFONAVIT se expressava em subsídio ao crédito, que, em muitos casos, era considerado "dádiva" do governo em curso, ou simplesmente se transformava em benefício pela diferenciação das taxas inflacionárias. No período de 1972 a 1987, as taxas dos créditos hipotecários eram fixadas em 4\% anualmente; porém, durante esse período, os índices inflacionários anuais ultrapassavam $40 \%$ ao ano, o que significava um diferencial de 36 pontos percentuais anuais. Assim, o INFONAVIT enfrentou graves problemas, sendo que a recuperação dos créditos era pequena e lenta, causando um desequilíbrio do sistema. 
A partir do final da década de 1980, as regras relativas ao INFONAVIT se alteraram, em especial em relação à sua perenidade quando da liberação de créditos, gerando reais recursos para sua efetiva recuperação e expansão das atividades. As amortizações dos créditos passaram a se vincular ao reajuste dos salários, evitando, desta forma, a desvalorização desses mesmos créditos num cenário de inflação elevada.

Na década de 1990, o INFONAVIT deixou de administrar as construções diretamente assim como a supervisão de obras. A responsabilidade quanto ao licenciamento dos conjuntos habitacionais passou a ser delegada aos municípios, e o órgão se transformou em uma entidade financeira de cunho hipotecário, destinando seus recursos principalmente às famílias de renda média e baixa.

Atualmente, o INFONAVIT administra um fundo formado por depósitos das empresas, em contas individuais dos seus funcionários, capta recursos lastreados em hipotecas emitidas e repassa aos associados na forma de crédito, conforme pontuação estabelecida pelo histórico de cada mutuário. Os recursos do instituto são complementados com subsídios oferecidos pelo governo federal.

Um aspecto importante do funcionamento desse sistema é que os procedimentos para concessão do crédito utilizando recursos do INFONAVIT ocorrem de forma transparente, sem burocracia e complicações, e podem ser acompanhados passo a passo pela Internet.

Nos dias atuais, as taxas de juros dos empréstimos do INFONAVIT são menores que as de mercado e diferenciadas por faixa de renda, podendo ser de $6 \%$ a $9 \%$ a.a., mais a variação do salário mínimo; o prazo de financiamento ocorre em até 30 anos, e o limite de crédito varia de US\$ 43.000 e US\$25.210. (FGV PROJETOS, 2007).

No ano de 2007, o valor dos subsídios incluídos no orçamento do governo federal mexicano foi de US\$ 354,8 milhões, sendo que, somados aos demais programas habitacionais, os recursos para o setor totalizavam US\$ 600 milhões. A tabela 12 apresenta as regras para se obter subsídios do governo federal: 
TABELA 12 - REGRAS PARA SE OBTER SUBSÍDIO DO GOVERNO FEDERAL MEXICANO

\begin{tabular}{|l|l|}
\hline \multicolumn{1}{|c|}{$\begin{array}{c}\text { VALORES MÁXIMOS DE } \\
\text { SUBSÍDIO }\end{array}$} & \multicolumn{1}{c|}{ CONDIÇÕES } \\
\hline US\$ 3.643 para moradia nova & O subsídio é concedido uma única vez \\
\hline US\$ 3.920 para moradia usada & Crédito inferior a US\$ 11 mil \\
\hline US\$ 3.282 para autoconstrução & Valor da moradia inferior a US\$21,5 mil \\
\hline US\$ 1.094 para reforma & Poupança prévia de no mínimo 4\% do valor da moradia \\
\hline US\$ 2.735 para compra de lote & \\
\hline
\end{tabular}

Fonte: FGV Projetos, 2007.

Com base na tabela acima, a FGV fez uma simulação das condições pré-estabelecidas para aquisição de unidade habitacional:

\section{TABELA 13 - SIMULAÇÃO DAS CONDIÇÕES PRÉ-ESTABELECIDAS PARA AQUISIÇÃO DE UNIDADE HABITACIONAL}

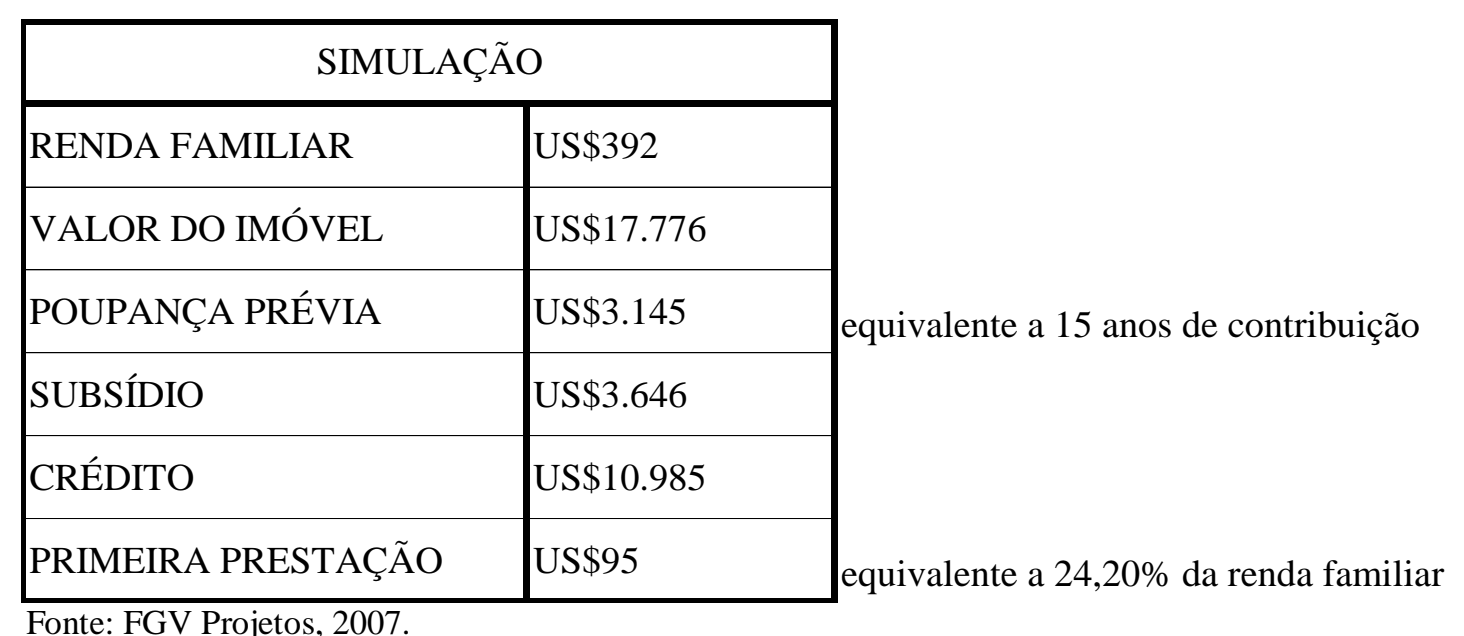

O gráfico 17 mostra a distribuição da concessão de créditos mexicanos no ano de 2006: 


\section{GRÁFICO 17 - EMISSÃO DE CRÉDITOS MEXICANOS - 2006}

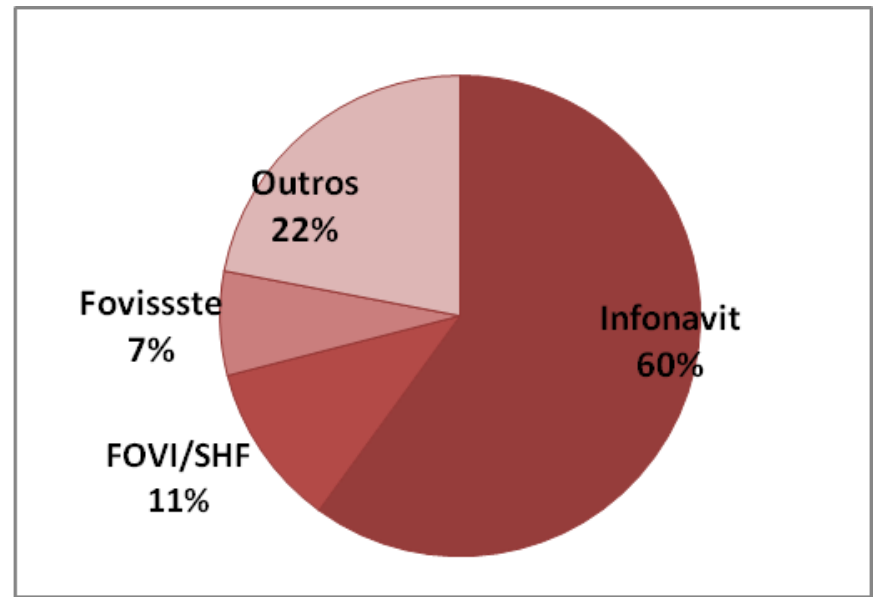

Fonte: Credit Suisse, 2005

Para reforçar o valor patrimonial da unidade financiada com recursos do INFONAVIT, o instituto promove vários mecanismos e incentivos. De modo a garantir que o preço pago se assemelhe ao de mercado, desde 2004, é exigida uma avaliação do valor do imóvel quando finalizada sua construção; outros mecanismos são a inclusão de uma garantia de qualidade, além do seguro do imóvel.

\subsubsection{SOBRE A ALOCAÇÃO DE RECURSOS DO INFONAVIT}

Atualmente, o objetivo central do INFONAVIT é atingir, basicamente, o público com renda de até quatro salários mínimos, de modo que $60 \%$ dos créditos destinados sejam direcionados aos mutuários que não são atendidos pelo setor privado.

O setor privado mexicano alcança a população com faixa de renda superior a 4,5 salários mínimos, para a qual a concessão de crédito do INFONAVIT diminui de modo inversamente proporcional, ou seja, quanto maior a faixa de renda, menor o percentual de crédito obtido, o que obriga o mutuário a buscar financiamento em outras instituições financeiras.

Uma alternativa estudada pelo INFONAVIT é, futuramente, atender somente dois tipos de públicos: os mutuários que não conseguem crédito do setor privado e aqueles com 
maior faixa de renda, tomando por base um co-financiamento, ou seja, o mutuário se adequaria às condições dos produtos que hoje são ofertados pelo setor privado.

O objetivo fundamental para o desenvolvimento do INFONAVIT é manter sua função social, oferecendo crédito para a população de baixa renda e, ao mesmo tempo, remunerando adequadamente o fundo.

O modelo de operação do INFONAVIT está baseado em uma cadeia de valor integrada por três funções que lhe dão sustentabilidade: arrecadação fiscal, originação de crédito e administração de carteira. Já sua estratégia financeira está baseada em dois eixos principais.

O primeiro eixo garante que todo crédito emitido deve ter um retorno suficiente e competitivo, sendo necessário, para tanto, definir índices de empréstimos vencidos aos padrões internacionais, que permitam pagar um retorno real de $4 \%$ para o mutuário. Alcançar esses índices de carteira vencidos implica originar ativos de melhor qualidade, além de assegurar o cumprimento das obrigações patronais de pagamento. Para tanto, foram estabelecidos critérios de equidade e risco às regras de concessão de crédito, além de políticas de reservas com base em padrões de mercado.

O segundo eixo da estratégia do INFONAVIT refere-se à possibilidade de recorrer ao mercado financeiro, após ter conseguido sanar seus balanços, no intuito de captar recursos adicionais, potencializando assim sua capacidade de concessão de crédito imobiliário por meio de emissões de Certificados de Vivienda, CEDEVIS. Tal procedimento resultou em uma classificação junto à Agência Internacional Standard \& Poor's, em que o México estaria no Grau de Investimento, o que significa que o instituto conta com a capacidade financeira para enfrentar suas obrigações de crédito dentro do mercado mexicano, considerando inclusive que, a médio ou longo prazo, os aportes feitos pelo emprego formal ao INFONAVIT, somados à recuperação da carteira hipotecária, serão significativamente maiores que os compromissos financeiros assumidos. 


\section{A PERSPECTIVA BRASILEIRA E OS AJUSTES NECESSÁRIOS PARA O FINANCIAMENTO HABITACIONAL}

Este capítulo aborda os pontos positivos do sistema mexicano e as possibilidades de aplicação à realidade brasileira. São analisados também os desafios a serem enfrentados pelo Brasil para avançar no sentido de conceder crédito à população de baixa renda e, ainda, as soluções urbanas de uso e ocupação do solo empreendidas por ambos os países.

\subsection{APLICAÇÃO DE INICIATIVAS MEXICANAS AO BRASIL}

Várias foram as medidas mexicanas voltadas à habitação e que poderiam ser aplicadas à realidade brasileira. Conforme visto anteriormente, o México possui um sistema habitacional essencialmente semelhante ao nosso, permitindo que se torne uma referência para o Brasil, consideradas, evidentemente, as diferenças existentes entre os modelos de ambos os países, conforme descrito anteriormente.

As reformas efetuadas pelo México em seu sistema de financiamento imobiliário e em sua política de subsídios habitacionais conseguiram responder com êxito à demanda de moradias no país, em especial para a população de baixa renda. Entre outros fatores, isso ocorreu pela concessão de crédito à população. As políticas de subsídios diretos serviram como catalisadores no processo de expansão da oferta de recursos, permitindo o acesso dos trabalhadores ao mercado de financiamento imobiliário, sendo que algumas situações que contribuíram para isso foram: estabilidade econômica do período, redução das taxas de juro e mecanismos introduzidos no sistema de financiamento habitacional, possibilitando a securitização de hipotecas. Assim, tanto o crédito imobiliário se tornou rentável junto ao mercado de capitais, quanto os custos dos financiamentos imobiliários se tornaram mais baixos. Esses avanços tornaram também o crédito atrativo em relação a investimentos estrangeiros.

Em comparação com a situação brasileira, é possível constatar uma tendência no México de queda das taxas de juro (apesar de, em alguns momentos, elas voltarem a subir, como no segundo trimestre de 2010), permitindo que o crédito imobiliário passasse a ficar ao alcance de grupos de renda cada vez mais baixa. 
Em oposição, no Brasil, os mecanismos de criação e ampliação do mercado secundário ainda são praticamente inexistentes, e a circulação dos CRIs, das Letras Hipotecárias e Letras de Crédito Imobiliário ainda é restrita. Os recursos do FGTS e das Cadernetas de Poupança encontrarão, em breve, os seus limites em termos de capacidade de disponibilizar recursos para financiamento habitacional. De acordo com dados da Abecip e BCB (2010), representados no gráfico 18, a partir de 2013 o estoque de financiamentos representará mais de $65 \%$ do saldo de poupança.

\section{GRÁFICO 18 - COMPARAÇÃO ENTRE O ESTOQUE DE FINANCIAMENTOS E O FUNDING NO SBPE}

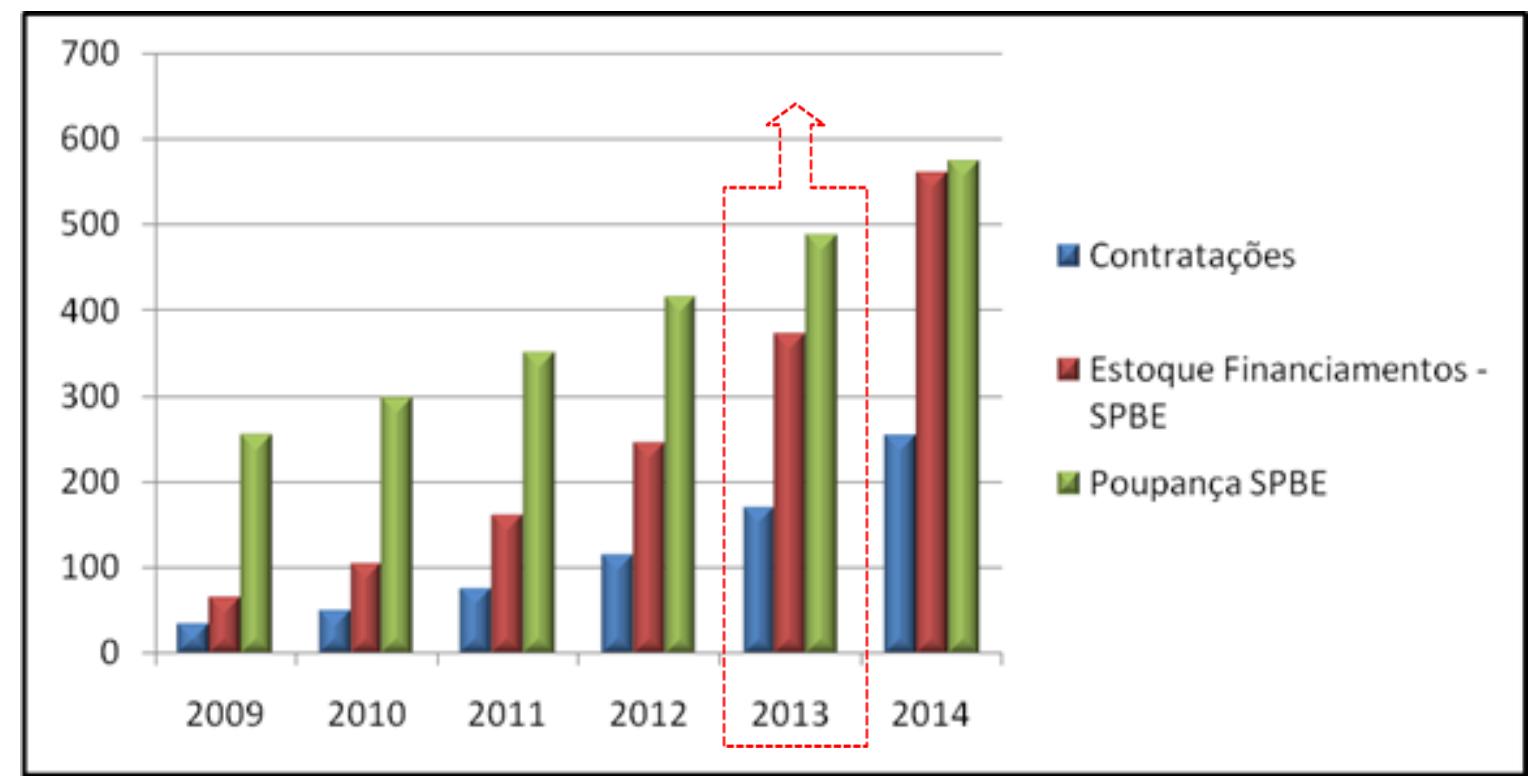

Fonte: BCB e ABECIP , 2010.

A consolidação de um mercado secundário no Brasil, de maneira a carrear recursos novos, e que agreguem as duas fontes hoje existentes, é condição sine qua non para que o sistema financeiro continue a expandir a oferta de crédito para imóveis, especialmente os residenciais. Porém no Brasil, isto não será possível até que caiam ainda mais as taxas de juros praticadas.

No caso do México, a oferta de crédito pelos fundos habitacionais e instituições financeiras, subsídios pelo governo e produção de moradias pelas construtoras estabeleceram um quadro adequado para que a população de baixa renda adquira seu imóvel próprio. 
Como vimos, um dos aspectos de sucesso nas políticas habitacionais mexicanas foi a modernização do INFONAVIT, cuja estrutura oferece crédito automático com base em pontuação, considerando os seguintes fatores: idade, renda, tempo de trabalho, tempo de contribuição, montante acumulado na conta, montante poupado voluntariamente. $\mathrm{O}$ INFONAVIT capta ainda fundos no mercado no intuito de complementar seus recursos em operações lastreadas por suas hipotecas. O processo é ágil, e o crédito pode ser aprovado no ato da compra ou no próprio escritório de vendas das construtoras. O financiamento é válido para moradias novas, usadas, construções em terreno próprio, ampliações ou reformas.

Essa sistemática de crédito pré-aprovado, com base em sistemas de pontuação, poderia ser aplicada pelo FGTS no Brasil. Assim, o mutuário acumularia pontos de acordo com alguns fatores: tempo de permanência no sistema, idade, condições socioeconômicas, valor de contribuição ao FGTS, de modo que pudesse se inteirar do valor do financiamento que lhe seria dado, qual a parcela do subsídio, juros de acordo com a faixa de renda, desburocratizando o processo. Atualmente, o FGTS é constituído por regras extremamente rígidas e burocráticas, que criam entraves ao uso dos recursos disponibilizados pelos trabalhadores da ativa. Flexibilizá-las, tornando o processo mais rápido e facilmente disponível, não é a solução para os limites de volume de crédito necessário nos próximos anos, mas pode contribuir para isso.

O subsídio ofertado deve ser inversamente proporcional ao valor do crédito requerido, e as futuras contribuições do trabalhador ao fundo se tornam garantias de sua dívida retornando ao fundo (no caso o FGTS) e não mais para a conta individual do trabalhador.

Outra solução adotada no México foram as Sociedades Hipotecárias Federais, criadas com respaldo de recursos governamentais, principalmente com aportes para montar seu capital, e que, a partir de 2013, passará a se manter por seus próprios meios. Para viabilizar crédito para baixa renda, as SHF atuaram na oferta de seguros contra a inadimplência, além do descasamento dos indexadores dos contratos e dos salários (FGV, 2007).

O mercado secundário no Brasil é essencial para atrair mais recursos ao sistema; porém, quando se trata de habitação popular, a falta de garantias gera insegurança aos agentes financeiros.

O mecanismo de seguro de crédito poderia contribuir de maneira relevante para o aumento da oferta de recursos para financiamento imobiliário, em especial para os mutuários de menor renda. O ideal seria que esse seguro fosse acionado em caso de inadimplência, 
também cobrindo eventuais diferenças entre valor financiado e valor recebido, impostos e despesas judiciais.

No Programa "Minha Casa, Minha Vida” é utilizada a figura do Fundo Garantidor em substituição ao seguro bancário. Trata-se de um fundo composto de recursos orçamentários que cria um seguro prestamista a ser utilizado, se necessário, para cobertura de inadimplência de até 36 parcelas no caso das unidades destinadas a famílias com renda entre três e seis salários mínimos. Desta maneira, os recursos empregados para o financiamento dessas unidades apresentam menor custo para o adquirente e menor risco para o crédito concedido, com redução no custo efetivo do seguro das operações de crédito. A crítica ao sistema é que o adquirente poderá acionar o fundo apenas comunicando a impossibilidade de pagamento para a instituição, por motivos como desemprego ou doença, gerando uma demanda difícil de mensurar, suscetível a fraudes e que poderá trazer despesas consideráveis ao tesouro.

No intuito de aprimorar as garantias por meio de recursos orçamentários, a equalização do risco do crédito, sem incorrer em custos adicionais aos mutuários, seria desejável. Além disso, esse tipo de recurso, funcionando no formato de um fundo, em regime de créditos rotativos, poderia contribuir para o financiamento de vários mutuários sucessivamente, uma vez que, seja em caso de inadimplência, quando haveria o pagamento pelas seguradoras, seja no caso do pagamento regular das prestações, o fundo teria seus recursos sempre renovados. Esse tipo de mecanismo contrasta com a concepção do programa "Minha Casa Minha Vida", que não tem a perspectiva de renovação e perpetuação de seus mecanismos de financiamento como alicerce de seu funcionamento.

\subsection{BARREIRAS AO DESENVOLVIMENTO DO CRÉDITO BRASILEIRO}

Para os clientes sociais, é difícil apresentar propostas ao sistema de financiamento imobiliário sem desenvolver uma política de crédito com a presença de subsídio.

No Brasil, várias foram as iniciativas que representaram avanço para o setor habitacional: de um lado, a criação do SNHIS, que articula e coordena as ações de instituições e órgãos com funções no setor da habitação; de outro, o FNHIS, que centraliza os recursos destinados ao subsídio habitacional, evitando que se dispersem em diferentes programas, facilitando sua gestão e dando foco ao emprego desses recursos. 
Para ser sustentável, a política habitacional deve reconhecer a existência de três segmentos a serem atendidos: famílias sem capacidade de pagamento; famílias com capacidade parcial de pagamento e famílias com plena capacidade de pagamento. O primeiro grupo tem como opção apenas programas em que o subsídio público para a compra é integral, não retornável ao sistema. O segundo grupo, ou seja, com capacidade parcial de pagamento, é composto por aqueles que têm acesso ao chamado financiamento social (foco do programa "Minha Casa Minha Vida") no momento da aquisição do imóvel para os projetos enquadrados no programa. Já o terceiro grupo pode ser atendido diretamente pelo mercado. No caso mexicano, essa organização por grupos ocorreu de tal forma que facilitou o atendimento das famílias de baixa renda.

Para Nascimento (2008), uma política pública adequada para financiamento popular deve envolver uma combinação de incentivos: redução da taxa de juros, indexação das prestações, além de subsídio oficial para os indivíduos de baixa renda.

De fato, como ressaltam Carneiro e Valpassos (2003), não se obtém sucesso na redução do déficit habitacional para a população de baixa renda sem a participação do governo no setor de financiamento imobiliário. A iniciativa privada acaba por não ter uma atuação relevante, tendo em vista a impossibilidade de os mutuários arcarem com os juros cobrados pelo mercado, por possuir maior sensibilidade a crises econômicas, elevando em demasia o risco de concessão de crédito para essa faixa de renda. No Brasil, vale mencionar, tem-se a maior taxa de juros do mundo, o que impossibilita a tomada de crédito de longo prazo pela maior parte da população.

Características próprias de nosso mercado também poderiam ser mencionadas, como por exemplo, a autoconstrução. Uma parcela considerável das unidades residenciais brasileiras é feita por meio deste "sistema". Desta forma, parte significativa da população acaba construindo irregularmente em áreas públicas com problemas fundiários ou inadequadas para implantação, não respeitando o regramento municipal quanto a aproveitamento, ocupação ou uso permitido, e também em áreas desprovidas de infraestrutura, o que gera problemas ambientais e estruturais para a cidade. Trata-se, porém, de uma solução de moradia adotada pela maioria da população carente - a produção habitacional não envolve assessoria técnica, o que, na prática, gera unidades de baixa qualidade construtiva, refletindo diretamente na vida de seus moradores.

Nesse cenário, o financiamento de lotes urbanizados poderia trazer duplo benefício, na medida em que o valor reduzido do financiamento, quando comparado ao de um imóvel 
pronto, possibilitaria que o subsídio dado pelo governo atingisse um maior número de pessoas e, ao mesmo tempo, possibilitasse um crescimento mais ordenado de nossas cidades. Nas regiões metropolitanas, a oferta de terrenos urbanizados dotados de infraestrutura poderia ser uma ferramenta importante para a redução da pressão gerada por essa demanda não atendida pelo sistema atual, que gera as ocupações irregulares.

Nesta perspectiva, é importante citar uma ferramenta importante aprovada em lei federal de 2009: a assistência técnica gratuita, que possibilitaria acompanhamento das construções, reduzindo riscos de emprego inadequado de recursos e outros problemas de habitabilidade. Com isso, famílias sem condições econômicas de construir podem contar com a assistência técnica e suporte financeiro dos órgãos públicos, além do fato de o programa prever a participação ativa dos beneficiários, bem como do poder público local, possibilitando a redução de custos de produção, de modo que o município reverta economias em melhorias urbanas para a cidade.

Alguns aspectos relevantes devem ser destacados como empecilhos para o sistema habitacional brasileiro. A estabilidade econômica é primordial para a manutenção de taxas de inadimplência em níveis normais, sendo condição essencial para os investidores garantirem o retorno do capital investido. Outro aspecto diz respeito às altas taxas de juros - em países como o Chile e México, o crescimento do crédito imobiliário só se deu a partir do momento em que essas taxas ficaram abaixo do patamar de $10 \%$. Neste sentido, tanto o Brasil como o México estão em patamares semelhantes e avançam cada vez mais, porém estão muito aquém de países mais maduros nesse quesito, como o Chile, por exemplo.

Em relação ao arcabouço legal, a legislação clara e o cumprimento de contratos são essenciais para o crescimento na concessão de créditos imobiliários, verificado o longo prazo do retorno dos financiamentos. Nessa linha, apesar de o Brasil estar bem posicionado e mais desenvolvido do que o México, muito ainda temos a crescer.

Um grande obstáculo brasileiro para o desenvolvimento do crédito habitacional é a dificuldade de obtenção de dados, que, em geral, são escassos, prejudicando análises do histórico ocorrido, bem como tomadas de decisões sobre investimento. 


\subsubsection{AS SOLUÇÕES URBANAS, O USO E A OCUPAÇÃO DO SOLO MEXICANO E BRASILEIRO}

Apesar do trabalho tratar do crédito habitacional verifica-se uma dificuldade em se desvincular a engenharia financeira com a qualidade da produção ou ainda com as soluções urbanas de uso e ocupação de solo e portanto deverão ser analisadas.

Mesmo com a implementação de soluções positivas que impactaram na quantidade de crédito imobiliário concedido pelo México, deve-se apontar também algumas características urbanísticas empregadas, ainda que não seja este o foco principal do presente trabalho.

Nas comunidades mexicanas, muitos são os problemas que a população enfrenta em relação ao modelo de empreendimento escolhido, qual seja, a implantação de grandes núcleos habitacionais de até 2.000 unidades, distantes dos centros urbanos. No que se refere à infraestrutura, nem sempre se observa a existência de abastecimento adequado de água e coleta de esgoto, e na maioria dos casos há grandes dificuldades de acesso, devido à inexistência de transporte público ou às enormes distâncias que a população necessita percorrer, seja no deslocamento de casa ao local de trabalho, seja dentro do próprio empreendimento, o que é bastante oneroso.

Apesar de mostrar-se correto sob o ponto de vista da produção, gerando ganhos nos processos em termos de escala, de fato, esse modelo de empreendimento causou impacto negativo no que se refere à mobilidade urbana. A opção ocorreu devido à necessidade de grandes áreas para implantação, disponíveis a valores acessíveis justamente por estarem nas periferias das cidades. Por meio de legislação específica para resolver problemas fundiários, o governo mexicano conseguiu disponibilizar grande número de glebas nessas regiões periféricas para aplicação de sua política habitacional e expansão das áreas urbanas.

Nesse aspecto, observa-se grande vantagem sob o ponto de vista do adquirente brasileiro de unidades de habitacionais financiadas pelo FGTS, cujos recursos só podem ser empregados em unidades com infraestrutura, inclusive no entorno do empreendimento, e não somente na unidade habitacional.

No Brasil, por meio dos processos de licenciamento, os empreendedores ficam submetidos a uma série de exigências legais, mesmo para habitação popular. A legislação brasileira determina destinações de percentuais de áreas de lazer e outras destinadas a uso institucional, além da obrigação de implantação das redes de abastecimento de água, coleta de esgoto, energia elétrica e iluminação pública. Em alguns estados, a legislação específica ainda 
exige transporte e equipamentos públicos a distâncias razoáveis para que esses empreendimentos possam contar com financiamento público ou benefícios tributários. Os empreendedores ficam submetidos a processos de licenciamento tanto nos municípios quanto nos estados, de maneira a reduzir impactos na implantação desses empreendimentos. A desvantagem é que a sobreposição desses licenciamentos gera elevados custos e prazos para implantação.

Vale ressaltar que experiências anteriores no Brasil na implantação de empreendimentos de habitação popular de grande porte geraram resultados bastante questionáveis, sendo os impactos sentidos até hoje, como no caso do BNH na década de 1970. Municípios ou regiões inteiras ficaram estigmatizados como "cidades dormitórios", com baixa atividade econômica e dependência de meios de transporte de alta capacidade para deslocar sua população ativa às áreas onde se concentram as atividades econômicas. Até o momento, as autoridades têm se preocupado em limitar o tamanho desses empreendimentos de forma a minimizar problemas dessa natureza.

\subsubsection{A INSEGURANÇA JURÍDICA BRASILEIRA}

Considera-se que a insegurança jurídica é uma barreira importante para o desenvolvimento de políticas de crédito, principalmente pelo fato de aumentar o custo do financiamento verificado o aumento do risco a ser assumido pelo empreendedor.

Quando se trata de questões relacionadas à insegurança jurídica, várias podem ser citadas, mas, no caso do Brasil, o licenciamento dos empreendimentos é a mais importante delas.

A primeira barreira a ser considerada é a da legislação. Em geral, os projetos são submetidos a procedimentos de licenciamento pouco claros e objetivos, ficando o empreendedor sujeito, por exemplo, à interpretação das exigências dos órgãos licenciadores feita pelo técnico que analisa o projeto. Esta é, basicamente, a origem da fragilidade dos processos de licenciamento, que, quando questionados por terceiros junto ao ministério público, por exemplo, geram procedimentos de embargo ou cancelamento de licenças, causando insegurança jurídica e prejuízo ao ambiente dos negócios. Para que isso não ocorresse, seria necessária a reordenação da legislação específica, bem como dos procedimentos necessários à concessão das licenças pelos órgãos concedentes. 
Outro fato que poderia contribuir de maneira objetiva para a melhoria do sistema é a definição das atribuições nos processos de licenciamento dos diversos entes federativos. A sobreposição dessas atribuições faz com que muitas licenças concedidas pelo poder público municipal sejam questionadas pelos órgãos estaduais e também pelo ministério público, em empreendimentos licenciados. Novamente, a falta de clareza nos procedimentos gera insegurança jurídica.

O terceiro fator que pode ser citado é a ausência de prazos para análise de processos de licenciamento, o que também gera insegurança e custos ao empreendedor, sendo de simples solução, caso haja investimento em planejamento, gestão e definição de prazos na própria legislação.

A excessiva burocracia existente no ato do registro do empreendimento também pode ser citada como mais um fator que traz insegurança. $\mathrm{O}$ excesso de certidões de diversas comarcas não garante a segurança do empreendimento. Nesse cenário a importância do conceito da concentração das matrículas é fundamental. O princípio é que qualquer ônus que recair sobre o proprietário, pessoa física ou jurídica, ou propriedade, esteja registrado em um único documento, desburocratizando e simplificando os procedimentos.

Tal medida contribui em larga escala na redução do financiamento, com aumento da segurança jurídica nas questões fundiárias, dando maior transparência e melhorando a qualidade da garantia, que é o próprio imóvel. Como consequência, tem-se a redução do valor do seguro, que, em financiamentos para essa faixa de renda, chega a custar $27 \%$ do valor das prestações.

Eliminar burocracias institucionais que retardam os procedimentos nas aprovações pode incentivar os empreendedores, principalmente os internacionais, a investirem no país. E também compatibilizar as regras, em especial as ambientais ${ }^{6}$, nas três esferas de governo (União, Estados e Municípios), definindo com clareza e objetividade as legislações as quais as áreas estão sujeitas.

\footnotetext{
${ }^{6}$ A legislação ambiental deve sim ter como objetivo central a proteção ao meio ambiente, porém de forma que possibilite o desenvolvimento responsável e sustentável.
} 


\subsubsection{O SUBSÍDIO HABITACIONAL}

Conforme abordado na introdução desta pesquisa, em oposição aos clientes bancários, os clientes da sociedade são aqueles que necessitam de intervenção do Estado para ter acesso à habitação popular, o que se dá com subsídio oferecido pelos órgãos governamentais.

Em geral, os mercados formais são ineficientes no atendimento à população de baixa renda. Como ressalta Fergunson (2004), 65\% da população da América Latina não consegue adquirir a mais barata das habitações. A solução para essas famílias é dividir moradias com parentes ou alugar residências subnormais ${ }^{7}$.

Para Hoek-Smit (2003), engana-se quem acredita que subsídio é dar ou receber algo gratuitamente. Trata-se de um incentivo que tem como objetivo persuadir uma classe a fazer algo que, de outra forma, não faria, simplesmente pela diminuição do custo de oportunidade. O importante, antes de se propor uma política de subsídios, é conhecer profundamente as causas das dificuldades encontradas. É necessário identificar se existe a necessidade de subsídios ou se bastam simplesmente adequações e regulamentações no setor.

Ainda para a mesma autora, as políticas de subsídio devem vir acompanhadas de outras ações governamentais, para que haja uma maior facilidade junto, principalmente, às entidades financiadoras e produtoras de habitações. Além disso, o sistema de regulamentações deve ser repensado, para que mais pessoas tenham acesso à habitação adequada. Se medidas complementares, como a aquisição de terra, produção, consumo, financiamento e infraestrutura, fossem pensadas e trabalhadas de forma eficiente, eventualmente, poderiam substituir políticas de subsídio.

Existem diversas formas de subsídios para habitação; porém, o importante não é o uso ou não desse recurso ou ainda o tipo a ser proposto, e sim os objetivos dessas políticas de intervenção governamental no mercado habitacional.

No Brasil, assim como em diversos países emergentes, a capacidade de financiamento das famílias é pequena em relação ao preço de uma habitação adequada ${ }^{8}$. Como resultado, os subsídios se tornam ferramentas fundamentais para possibilitar o acesso a moradias de

\footnotetext{
${ }^{7}$ Habitação subnormal é definida "como aquela que não oferece as condições mínimas de segurança, durabilidade, tamanho, salubridade e não permite a seus moradores o atendimento das atividades como membro de grupos primários" (Abiko, 1995, p. 12).

${ }^{8}$ Entende-se por habitação adequada aquela unidade habitacional servida por infraestrutura, ou seja, abastecimento de água, coleta de esgoto, rede elétrica, coleta de lixo, conforme conceituado no capítulo 1 desta pesquisa.
} 
qualidade. Sem eles, a população tende a buscar o setor informal ou financiamentos parciais, que não atendem por completo suas reais necessidades.

Para Diamon e Hoek-Smith (2003), os programas de subsídios ${ }^{9}$ nem sempre são desenhados com objetivos específicos, bastando, muitas vezes, uma alteração na regulamentação para torná-los mais adequados.

Importante destacar que nem todos os subsídios habitacionais implicam em crédito subsidiado. O subsídio deve ser anterior ao financiamento, podendo inclusive influenciar o preço da moradia, de modo que o formato de isenção fiscal não interferira no valor financiado (RODRIGUES, 2009).

Hulse (2001) divide subsídio habitacional em dois grandes grupos:

1 - Subsídio à oferta e que tem como objetivo reduzir o custo da produção de unidades habitacionais;

2 - Subsídio à demanda, com o objetivo reduzir os custos da moradia.

Ambos podem ser concedidos diretamente por meio de gasto público, ou indiretamente por meio do sistema tributário.

Para Diamond e Hoek-Smith (2003), os subsídios à demanda podem não estimular a produção de certos tipos de moradias ou de produtos de crédito e só são válidos quando combinados com medidas que reduzam os riscos do investimento para o empreendedor e consumidor, seja por meio de subsídios à oferta, medidas regulatórias ou mudanças institucionais.

No Brasil, deve haver muito critério na criação de programas de subsídio habitacional, de modo a não se excluir pessoas de baixa renda, uma vez que muitas possuem problemas para fornecer garantias ou podem ter dificuldades de acesso ao mercado formal de crédito, podendo, desta forma, afetar negativamente a distribuição de renda do país. Também o México ainda não conseguiu, assim como o Brasil, solucionar o problema da informalidade no emprego, sendo o grande gargalo encontrado nos dois sistemas.

Para Rodrigues (2009), alternativas como o microcrédito ${ }^{10}$ devem ser levadas em consideração para a população de baixa renda no Brasil.

\footnotetext{
9 Alguns programas federais citados na seção 2.1 desta pesquisa tratam dos subsídios diretos propostos, como, por exemplo, o PSH e, mais recentemente, o programa federal "Minha Casa, Minha Vida"; os subsídios indiretos voltados à habitação popular são tratados no capítulo referente à questão tributária.
} 
Além dos problemas citados referentes ao subsídio, o maior diz respeito aos custos incertos e ocultos, que impõem restrições à eficiência dos mercados financeiros, impedindo a participação do setor privado.

\subsubsection{A FALTA DE PERENIDADE NOS PROGRAMAS HABITACIONAIS E NAS POLÍTICAS HABITACIONAIS}

Um dos aspectos positivos do modelo mexicano é a perenidade nos programas. A administração do sistema envolve Estado, trabalhadores e iniciativa privada (conforme tratado no item 3.3), não se vincula a políticas de governo ${ }^{11}$ e influências político-partidárias, gerando estabilidade de longo prazo.

Infelizmente, não é possível identificar esses aspectos no caso brasileiro. Na maioria das vezes, o programa acaba tendo a duração do governo que o lançou, não sendo prioridade para o seguinte, o que acaba prejudicando o foco nas políticas públicas habitacionais. $\mathrm{O}$ programa "Minha Casa, Minha Vida" pode exemplificar esse problema: o governo disponibilizou um valor finito de recursos, não propondo soluções que se retroalimentam e, portanto, acabam não produzindo efeitos duradouros.

Essa falta de visão da necessidade de implantação de políticas de estado perenes, devido à vinculação da solução do déficit habitacional a financiamentos de longo prazo, também contribui para a extensão do déficit por muito tempo.

Somente a partir de 2000 que o Brasil tem contado com um início de ênfase para o setor habitacional por parte do governo, porém, ainda muito aquém das necessidades da população, especialmente de baixa renda, de responsabilidade do Estado.

\footnotetext{
${ }^{10}$ Consiste em um empréstimo de baixo valor e na construção "progressiva" da residência, ou seja, em etapas. Requer pouco e em muitos casos nenhum subsídio, utilizado em países como o Chile, por exemplo.

11 O Banco do México, equivalente ao Banco Central brasileiro, trabalha de forma independente, não tem vínculo partidário, proporcionando uma continuidade à política econômica e gerando estabilidade no médio e longo prazo.
} 


\subsubsection{AS PRINCIPAIS DIFERENÇAS E SEMELHANÇAS NOS DOIS SISTEMAS}

Ao criar o INFONAVIT, o México se baseou em grande parte no sistema brasileiro, em especial no FGTS. O objetivo inicial do fundo não era o financiamento habitacional e sim assegurar proteção aos trabalhadores em caso de desemprego. Contudo, quando da criação do INFONAVIT, os recursos do FGTS já estavam sendo utilizados para o financiamento habitacional.

Muitas são as semelhanças nos dois sistemas em termo de conceito de captação dos recursos, embora alguns números sejam diferentes. No Brasil, são captados $8 \%$ mensalmente do salário do trabalhador, enquanto no México são $5 \%$ bimestralmente. A diferença principal na sistemática é que, no caso mexicano, o financiamento ocorre única e exclusivamente ao mutuário, que possui conta junto ao fundo, ou seja, dirige-se basicamente para o mutuário final.

Aqui, como citado no item 2.1.2, o FGTS financia vários outros setores da economia, perdendo o foco no objetivo principal, que é o financiamento habitacional. Por outro lado, nas comunidades planejadas mexicanas, como já dito, vários são os problemas em relação à infraestrutura e saneamento básico. As delegações brasileiras que foram visitar o país encontraram residências sem a operação de água e esgoto, o que não ocorre no Brasil. Para os empreendedores brasileiros, muitos são os critérios exigidos pelas concessionárias de água, esgoto e energia elétrica para a implantação de habitações, válidos também para as populares, o que é bastante louvável.

Outro aspecto relevante diz respeito à burocracia encontrada nos dois países. No México foram feitas alterações na legislação no intuito de desburocratizar procedimentos. Os mexicanos conseguem adquirir um financiamento habitacional no próprio stand de vendas das incorporadoras. A desburocratização não ocorre somente na emissão de créditos como também na transação de hipotecas. Já no Brasil, o excesso de burocratização diminui sensivelmente o ritmo, não só da emissão de créditos, iniciando-se já no momento de aquisição de áreas. São procedimentos longos e demasiadamente burocráticos desde as retificações de áreas, licenciamentos federais, estaduais e municipais, incorporações e registros imobiliários até a emissão do crédito. Nesse quesito acredita-se que o Brasil poderia adotar as soluções mexicanas, com a seriedade a que se propõe hoje, porém de modo a agilizar os processos. 
Mas há semelhanças entre os dois países. Em ambos pode-se observar uma melhora significativa em relação à eficiência quando da recuperação de garantias. No caso brasileiro denomina-se alienação fiduciária, citada anteriormente, e que garante a mitigação de riscos em empreendimentos imobiliários. O México também conquistou essa segurança junto à sua legislação propiciando atratividade para investidores.

Outra semelhança diz respeito ao fato de que nenhum dos dois países conseguiu solucionar a questão de atingir a informalidade no emprego. Tanto o INFONAVIT como o FGTS exigem que mutuário final tenha carteira assinada; porém, a informalidade é grande nos dois países, especialmente para população de baixa renda em que se encontra o déficit habitacional.

Tanto o México quanto o Brasil possuem históricos econômicos semelhantes, como citado anteriormente. Hoje, ambos estão atingindo sua estabilidade econômica e tentando reduzir taxas de juros para alcançar índices aceitáveis, no intuito de propiciar, de fato, a emissão de créditos em grande escala.

Abaixo, segue tabela contendo aspectos positivos e negativos em cada um dos países:

TABELA 14 - OS DOIS SISTEMAS E OS PRINCIPAIS ASPECTOS

\begin{tabular}{|c|c|c|}
\cline { 2 - 3 } \multicolumn{1}{c|}{} & BRASIL & MÉXICO \\
\hline \multirow{2}{c|}{$\begin{array}{c}\text { ASPECTO } \\
\text { POSITIVO }\end{array}$} & PREOCUPAÇÕES URBANAS & DESBUROCRATIZAÇÃO \\
\cline { 2 - 3 } & POLÍTICAS DE GARANTIA & REFORMA PREVIDENCIÁRIA \\
\cline { 2 - 3 } & & MERCADO SECUNDÁRIO \\
\hline \multirow{2}{*}{$\begin{array}{c}\text { ASPECTO } \\
\text { NEGATIVO }\end{array}$} & FALTA DE PERENIDADE NAS & SOLUÇÕES URBANAS \\
\cline { 2 - 3 } & INSEGICAS HABITACIONAIS & \\
\cline { 2 - 3 } & QUESTÕES TRIBUTÁRIAS & \\
\hline
\end{tabular}

Fonte: elaborado pela autora. 


\section{CONCLUSÃO}

Identificadas as semelhanças entre o sistema habitacional brasileiro e mexicano, este trabalho buscou compará-los, concluindo que o México possui diversos aspectos que podem ser adaptados à realidade brasileira.

$\mathrm{Na}$ análise dos resultados obtidos pelo México em sua política habitacional nos últimos anos, é notória sua evolução, se comparados aos resultados das políticas brasileiras para o mesmo período. O salto foi dado no momento em que se equalizaram fontes de recursos, sistemas de concessão de crédito e definição do produto para a faixa de renda específica a que se destinava seu programa habitacional.

O Brasil já deu o primeiro passo nesse sentido, pois busca a manutenção da estabilidade econômica. Porém, muitos são os aspectos a serem enfrentados em conjunto com o setor produtivo para que o país possa efetivar uma política habitacional voltada à população de baixa renda, sustentável e estruturada o suficiente, dando início, assim, ao saneamento do déficit habitacional. Entre esses aspectos, destacam-se:

1. Políticas de subsídios adequadas à população de baixa renda

Refere-se à aplicação de políticas de subsídios, com a devida cautela para que estes não ocultem riscos ao retorno dos recursos. A longo prazo, um sistema eficiente poderá ser sustentável economicamente. Neste sentido, duas possibilidades devem ser analisadas: subsídio direto à produção das unidades via créditos para a construção, com juros baixos; subsídio indireto, por meio de isenções fiscais. Para o subsídio à comercialização deve-se analisar a primeira possibilidade, por meio de redução de custos de financiamento (o governo arcaria com o seguro, por exemplo), ou a segunda, por meio de isenção ou redução de impostos sobre o financiamento habitacional.

Considerando a importância de investimentos em saneamento e infraestrutura, pode-se pensar em um melhor direcionamento do FGTS para a habitação popular, de modo a não se diversificar a alocação, como ocorre na atualidade.

\section{Custos cartoriais}

A burocracia existente nas questões fundiárias, em que o processo de registro fica submetido a um número enorme de documentos e certidões, aumenta os custos e o período de 
maturação de um empreendimento. Uma reforma no sistema e a instituição do princípio da concentração das matrículas são necessárias para mudança desse cenário. No caso mexicano, foram efetuadas reformas nos sistemas cartoriais com regulamentação de questões possessórias que geram baixa oferta de áreas em condições de receber empreendimentos nos grandes centros urbanos e, como consequência, alto custo das propriedades.

3. Necessidade de outras instituições financeiras

A definição da CEF como agente operador e fiscalizador dos recursos do FGTS inibe a competitividade e o surgimento de outras instituições financeiras especializadas nesse nicho de mercado. Operando também como agente financeiro, a CEF detém a quase totalidade das operações de crédito vinculadas à conta do FGTS, parte pelas imposições da própria CEF, parte pelo baixo valor do spread embutido nessas operações. Para tanto, a CEF não deveria concorrer com juros subsidiados pelo trabalhador, o que impede que um maior número de instituições desenvolva soluções para essa modalidade de crédito.

Criar mecanismos para a entrada de outros agentes financeiros teria efeito, especialmente, na melhoria dos prazos e procedimentos para concessão do crédito, considerando que, mesmo com restrições quanto à eficiência da CEF, esta consegue atender a demanda. Neste sentido, alterações no âmbito legal e resoluções do BACEN seriam desejáveis.

\section{Dependência do FGTS}

Desde a vinculação de parte dos recursos do FGTS para financiamento da produção e aquisição de imóveis, o mercado deixou de desenvolver sistemas alternativos de captação de recursos para esses financiamentos, por incapacidade econômica de concorrer com crédito subsidiado.

É, pois, necessária a substituição do funding que a sociedade faz por meio do FGTS para o financiamento da produção e aquisição de habitações. A consolidação de mecanismos legais e tributários que viabilizem a substituição desses recursos por outros de mercado será possível com a estabilidade da economia em patamares de crescimento razoáveis e com taxas de juros aceitáveis, dando condição de o sistema financeiro como um todo concorrer com a CEF.

As ações empreendidas pelo México não são inovadoras, e nem de impossível implementação. O que há, de fato, é uma ênfase nas políticas públicas habitacionais, duas delas com resultados bastante significativos: 
$\checkmark$ Desburocratização de procedimentos, o que é essencial ao desenvolvimento do processo, principalmente quando se trata de população de baixa renda ou ainda com intuito de atender ao mercado informal de trabalho;

$\checkmark$ Perenidade, continuidade e sustentabilidade dos planos estratégicos de atuação, independente dos governos;

Apesar de identificar vários aspectos positivos na emissão de crédito mexicana e de fácil aplicação à sistemática brasileira observa-se que o Brasil está atuando em uma linha mais sólida e embasada, faltando apenas um amadurecimento do mercado de capitais com a regulamentação de procedimentos necessários a securitização, por exemplo, no intuito de alavancar o sistema. O México mesmo com os crescentes números possui uma sistemática um tanto quanto primária deixando a desejar no quesito urbanístico, verificado que as análises devem caminhar paralelamente.

Sem a pretensão de esgotar o tema, este trabalho buscou ressaltar algumas ações fundamentais para que as concessões de crédito à população de baixa renda atinjam números na escala necessária ao Brasil, tais como: “descolar" as políticas habitacionais das políticas partidárias, propiciando que as primeiras tenham sustentabilidade própria; desburocratizar procedimentos e alocar de forma mais específica os recursos destinados à habitação. O Brasil poderia solucionar, a médio prazo e de forma mais eficaz, os problemas habitacionais existentes utilizando experiências bem sucedidas já adotadas pelo México, como vimos, um país semelhante ao nosso em diversos aspectos.

Muitas são as barreiras a serem enfrentadas pelo setor habitacional brasileiro. Porém, entende-se que o cenário está se adequando a cada dia, para que o país, nos próximos anos, possa evoluir até ter condições de apresentar um mercado de crédito imobiliário sustentável, de forma que consiga iniciar a longa jornada no intuito de atender a população de baixa renda, que hoje representa $96 \%$ do déficit habitacional brasileiro. 


\section{BIBLIOGRAFIA}

ABECIP. SFI: Como funciona o novo Sistema de Financiamento Imobiliário. Associação

Brasileira das Entidades de Crédito Imobiliário e Poupança. São Paulo, 1997.

ABECIP Associação Brasileira das Entidades de Crédito Imobiliário e Poupança: Seminário Internacional de Crédito Imobiliário, 2007. 150p.

ABIKO, A.K. Introdução à Gestão Habitacional. São Paulo, EPUSP, 1995. (Texto Técnico da Escola Politécnica da USP. Departamento de Engenharia de Construção Civil, TT/ PCC/ 12).

ALVES, M. H. A. F. Financiamento de política estadual de habitação de interesse social. Salvador: Fundação Escola de Administração, Universidade Federal da Bahia, 2006. 34 p. Nota técnica - relatório preliminar.

ALVES, M. H. A. F. Financiamento de política estadual de habitação de interesse social. Salvador: Fundação Escola de Administração, Universidade Federal da Bahia, 2006. 34 p. Nota técnica - relatório preliminar. Por dentro do financiamento habitacional para baixa renda. [Entrevista a Ana Maria Castelo e Maria Antonieta Del Tedesco Lins]. Conjuntura da Construção, São Paulo, set. 2005.

ALVES, PAULO ROBERTO RODRIGUES. O desenvolvimento do sistema financeiro imobiliário e da securitização de recebíveis imobiliários na redução do déficit habitacional brasileiro. Monografia do Instituto de Economia da Universidade Feral do Rio de Janeiro, 79 p. Rio de Janeiro, 2005.

ARAGÃO JOSÉ MARIA, Sistema Financeiro da Habitação. Uma Análise Sócio-Jurídica da Gênese, Desenvolvimento e Crise do Sistema: 597 p., 1999

AZEVEDO, S. - Desafios da política federal de habitação popular no Brasil. Brasília: Secretaria Especial de Desenvolvimento Urbano da Presidência da República. 2002, 27 p. Artigo preparado para o Programa Habitar Brasil.

BANCO CENTRAL DO BRASIL - Sistema Financeiro da Habitação (SFH). Disponível em: www.bacen.gov.br/SFHHIST>.2006. 
BANCO CENTRAL DO BRASIL - Coleta de dados sobre o cenário econômico. Disponível em: www.bcb.gov.br. Acesso em maio de 2008.

BANCO CENTRAL DO BRASIL - Disponível em: www.bcb.gov.br. Acesso em 14 de dezembro de 2008.

BARREDA, FLÁVIO AUGUSTO FRANYUTI. O sistema de financiamento imobiliário no México. 2007, 150 p. Seminário Internacional de Crédito Imobiliário.

BRASIL. Controladoria Geral da União. Balanço-geral da união. Brasília: Controladoria geral da união, 2002.

BRASIL. Controladoria Geral da União. Balanço-geral da união. Brasília: Controladoria geral da união, 2002. Lei n ${ }^{\circ}$. 8.036, de 11 de maio de 1990. Dispõe sobre o Fundo de Garantia do Tempo de Serviço, e dá outras providências. Brasília: Diário Oficial da União, 14 mai, 1990.

BRASIL. Controladoria Geral da União. Balanço-geral da união. Brasília: Controladoria geral da união, 2002. Lei $\mathrm{n}^{\circ}$. 11.124, de 16 de junho de 2005. Dispõe sobre o Sistema Nacional de habitação de Interesse Social - SNHIS, cria o Fundo Nacional de Habitação de interesse Social - FHHIS e institui o conselho Gestor do FNHIS. Brasília; Diário Oficial da União, 17 jun. 2005 .

BOVESPA - Plano Diretor do Mercado de Capitais, 15p. Disponível em www.bovespa.com.br. Acesso em maio de 2009.

CARNEIRO,D.D.; VALPASSOS, M.V.F. - Financiamento à habitação e instabilidade econômica: experiências passadas, desafios e propostas para ação futura. Rio de Janeiro: FGV: 2003, 197p.

CARVALHO CE, Pinheiro MM. 2000. FGTS: avaliação das propostas de reforma e extinção. In: Economia e sociedade. Dezembro 2000. Campinas: Unicamp, Instituto de Economia.

CAIXA ECONÔMICA FEDERAL. Dados sobre a alocação dos recursos do FGTS por faixa de renda, 2007.

CAIXA ECONÔMICA FEDERAL. Disponível em: www.caixa.gov.br. 2009. Dados recebidos via e-mail, mar 2010. 
CAIXA ECONÔMICA FEDERAL. FGTS - Relatório de gestão - exercício 2008. Brasília: Caixa Econômica Federal, 2008. 324p.

CÂMARA BRASILEIRA DA INDÚSTRIA DA CONSTRUÇÃO - CBIC. Disponível em: www.cbic.org.br. 2009. Dados recebidos via e-mail, mar 2009.

CONAVI, Boomtown Mexico: an overview of the Mexican housing sector. Comisión Naional de Fomento a la Vivienda, 2006. 16 p.

COSTA, Ana Carla Abrão. Mercado de Crédito: uma análise econométrica dos volumes de crédito total e habitacional no Brasil. Trabalho para discussão n ${ }^{\circ} 87$. Banco Central do Brasil: Nov. 2004.

CREDIT SUISSE FIRST BOSTON. Latin American Banks/ Housing and Construction: when will Brazilian mortgages grow as they do in Mexico and Chile. CSFB, 2005. 53 p. Relatório de Análise de Mercado.

DENOR - Banco Central do Brasil. $13^{\circ}$ Fórum - Nov/ 2004. Acesso em 21/05/2009.

ESPINOSA, Marco, e ZANFORLIN, Luisa. Housing Finance and Mortgage-Backed Securities in Mexico. IMF Working Paper No.08/105. April 2008

FERGUNSON, B. Housing finance options for low and medium income families: analysis of the Latin America experience. Housing Finance International, v.18, n.3, p.11-14, Mar.2004. FGV. Lições do modelo do México de financiamento habitacional. 18 p. São Paulo, 2007.

FGV. O crédito imobiliário no Brasil: Caracterização e desafios. 48 p. São Paulo, 2007.

FUNDAÇÃO JOÃO PINHEIRO. Déficit habitacional no Brasil. Belo Horizonte: Fundação João Pinheiro, 1995. 141 p.

FUNDAÇÃO JOÃO PINHEIRO. Déficit habitacional no Brasil 2000. Belo Horizonte: Fundação João Pinheiro, 2000. 203 p. [Projeto PNUD-BRA-00/019 - Habitar-Brasil - BID].

FUNDAÇÃO JOÃO PINHEIRO. Déficit habitacional no Brasil 2000. Belo Horizonte: Fundação João Pinheiro, 2000. 203 p. [Projeto PNUD-BRA-00/019 - Habitar-Brasil - BID]. 
Déficit habitacional no Brasil 2005.Belo Horizonte: Fundação João Pinheiro, 2005. 200 p. [Projeto PNUD-BRA-00/019 - Habitar-Brasil - BID].

FUNDAÇÃO JOÃO PINHEIRO - Centro de Estatística e Informações. Déficit Habitacional no Brasil. Disponível em: www.fjp.gov.br/produtos/cei/deficit_2006.pdf acesso em 24 de fevereiro de 2009.

GOMES, AMARO LUIZ DE OLIVEIRA. Direcionamento dos Recursos de Poupança e o Desenvolvimento do Setor Imobiliário. Departamento de Normas do Sistema Financeiro GONÇALVES, Robson R. Aspectos da Demanda por Unidades Habitacionais nas Regiões Metropolitanas - 1995/2000. Texto para Discussão nº. 514. Rio de Janeiro: IPEA, set. 1997.

GONÇALVES, Robson R. O défici habitacional brasileiro: Um mapeamento por unidades da federação e por níveis de renda domiciliar - 1998. Texto para Discussão $n^{\circ}$. 559. Rio de Janeiro: IPE.

GREEN, Richard K., e WATCHER, Susan M. The American Mortgage in Historical and International Context. In: Journal of Economic Perspectives-Volume 19, N 4, 2005.

GUTTENTANG JM. 1998a. Reorganizing housing banks. In: Housing Finance International vol. março/1998. Londres: IUHF.

HARDT J., Lichtenberger JD. 2001. The economic and financial importance of mortgage bonds in Europe. In: Housing Finance International vol. junho/2001. Londres: IUHF.

HOEK-SMIT, M.; DIAMOND, D. B. Sudsidies for housing finance. Housing Finance International, Mar. 2003.

HULSE, Kath. Demand subsidies for private renters: a comparative review. Brisbane: 2001. Disponível em: <

http://www.nationalhousingconference.org.au/downloads/2001/DayTwo/02_kath_hulse.pdf $>$. Acesso em Março 2009.

IBGE, Instituto Brasileiro de Geografia e Estatística. Tendências Demográficas, 2001.

IBGE, Instituto Brasileiro de Geografia e Estatística. 2008 Índices de preços ao consumidor, séries históricas. Brasília: Fundação IBGE. 
KAMPEL, L. C.; VALLE; M.T.M. Sistema financeiro da habitação. Rio de Janeiro: Instituto Brasileiro de Mercado de Capitais, 1974. 207 p.

KOHLER, N. A. Financiamento habitacional. Brasília: Consultoria legislativa do Senado Federal; Coordenação de estudos, 2005. 36 p. (Texto para discussão, 29).

LIPSCOMB, J.B.; HARVEY; J.T., HUNT, H. Exchange-Rate Risk Mitigation with PriceLevel-Adjusting Mortgages: the case of the Mexican UDI. Journal of Real Estate Research, v.25, n.1, p.23-41, 2003.

LORENZETTI, M. S. B. A questão habitacional no Brasil. Brasília: Câmara dos deputados; Consultoria legislativa da área XIII, Desenvolvimento urbano, trânsito e transportes, Jul 2001. 25 p. (Estudo).

MARCONI, M. A.; LAKATOS , E.M. Metodologia do trabalho científico. 6ed. São Paulo: Atlas, 1994.

MEDEIROS, FÁBIO BONFIM, Análise da adequação dos programas de financiamento habitacional para atender as necessidades de aquisição de moradias adequadas da população de baixa renda no Brasil. 144 p. Dissertação (Mestrado), Escola Politécnica da Universidade de São Paulo, 2007.

MINISTÉRIO DAS CIDADES. Déficit habitacional no Brasil. Brasília: Governo federal, Secretaria Nacional de Habitação, 2006. 124 p.

MINISTÉRIO DAS CIDADES. Déficit habitacional no Brasil. Brasília: Governo federal, Secretaria Nacional de Habitação, 2009. 129p.

MINISTÉRIO DAS CIDADES. Política nacional de habitação. Brasília: Governo federal, Secretaria Nacional de Habitação, 2004. 86 p.

MORAES, DANIEL CARRASQUEIRA. O SFI: A Securitização como instrumento de fornecimento do Crédito Imobiliário. 156 p. Dissertação (Mestrado), Faculdade de Economia, Administração e Contabilidade da Universidade de São Paulo, 2008.

MORAIS, MARIA DA PIEDADE, Breve Diagnóstico sobre o quadro atual da habitação no Brasil,10p.,2002. Disponivél em 
http://www.ipea.gov.br/sites/000/2/publicacoes/bpsociais/bps_04/BREVE.pdf, acesso em 10 de dezembro de 2009.

OLIVEIRA, M. C. B. S., Política de habitação popular no Brasil: passado e presente. 2000. 170p. Dissertação (Mestrado) - Instituto de Pesquisa e Planejamento Urbano e Regional, Universidade Federal do rio de Janeiro, Rio de Janeiro, 2000.

PARKINSON, ARTHUR M., Mercado Habitacional Mexicano, 2006. 23p. Conselheiro SECOVI - SP.

PINCHERLE, SANDRO MARCONDES, Proposta para o desenvolvimento da moradia para as faixas de baixa renda, dentro da "Cruzada Fiabci pela Habitação Popular". Disponível em www.fiabcibrasil.com.br/.../SandroCruzadaTextodoSiteAFinal.doc . Acesso em junho 2009.

REVISTA CONJUNTURA DA CONSTRUÇÃO, México Lições de Política Habitacional, Ano V/n²/ Junho 2007.

RODRIGUES, LUIZA BETINA PETROLL, Crédito para habitação no Brasil: Histórico e Desafios. Dissertação de mestrado em economia. Pontifica Universidade Católica de São Paulo, 2009.

ROJAS E. 2001. The long road to housing sector reform: lessons from the chilean housing experience. Housing Studies. Vol.16, número 4. Londres: Carfax Publishing. P. 461-483.

ROSSBACH, Anacláudia Marinheiro Centeno. Financiamento habitacional no Brasil. Dissertação de mestrado em economia. Pontifica Universidade Católica de São Paulo, 2005.

ROYER L. 2002. Política habitacional no Estado de São Paulo: estudo sobre a Companhia de Desenvolvimento Habitacional e Urbano do Estado de São Paulo, CDHU. São Paulo: Faculdade de Arquitetura e Urbanismo/USP (mimeo: dissertação de mestrado). 209 p.

RUDGE, L.F.; AMENDOLARA, L. - Desvendando a rede dos financiamentos imobiliários. 1 ed. São Paulo: Pini, 1997, 111p.

SANTOS, C. H. M. A Dinâmica dos Mercados Habitacionais metropolitanos: aspectos teóricos e uma grande aplicação para a grande São Paulo. Brasília, Mar 2000. 28 p. (texto para discussão, n. 713). 
SANTOS, C. H. M. Políticas federais de habitação no Brasil: 1964/1998. Brasília: IPEA, 1999. 30p. (texto para discussão, n. 654).

SECRETARIA NACIONAL DA HABITAÇÃO. Dados sobre os investimentos em unidades habitacionais. Disponível em www.cidades.gov.br/secretarias-nacionais/secretaria-da-habitacao Acesso em setembro de 2008.

SILVA, MARCIO VENTURA DA. O financiamento imobiliário nos fundos de pensão / Marcio Ventura da Silva - Rio de Janeiro: Faculdades Ibmec, 2007.

SOFTEC. Mexican Housing Overview. México D.F.: SOFTEC, 2007.

SOUZA, R. C. O peso dos impostos na habitação de interesse social. Conjuntura da Construção, São Paulo, set. 2006.

TRIANA, A. F. Habitação popular no Brasil: análise do modelo operacional de financiamento pelas agências oficiais. 2006. 153 p. Dissertação (Mestrado) - faculdade de Arquitetura e Urbanismo, Universidades de Brasília, Brasília, 2006.

UNIÃO NACIONAL DA CONSTRUÇÃO, A construção do Desenvolvimento Sustentado: 38 p., 2007.

VASCONCELOS, J.R.; CÂNDIDO JÚNIOR, J. O problema habitacional no Brasil: Déficit, financiamento e perspectivas. Brasília: IPEA, 1996, 43 p. Texto para discussão, nº410.

VEDROSSI, Alessandro Olzon. A Securitização de Recebíveis Imobiliários: Uma alternativa de aporte de capitais para empreendimentos residenciais no Brasil. 123 p. Dissertação (Mestrado), Escola Politécnica da Universidade de São Paulo, 2002.

VEDROSSI, Alessandro Olzon. O financiamento imobiliário residencial no México e sua comparação com a realidade brasileira. 11 p. VII SEMINÁRIOS LARES - Latin American Real Estate Society, 2007. 


\section{BIBLIOGRAFIA CONSULTADA}

ABIKO, A.K. Reflexões sobre o parcelamento do solo urbano. São Paulo, EPUSP, 1998. (Boletim Técnico da Escola Politécnica da USP. Departamento de Engenharia de Construção Civil, TT/ PCC/ 201).

CAIXA ECONÔMICA FEDERAL. FGTS - Relatório de gestão - exercício 2008. Brasília: Caixa Econômica Federal, 2007. 320p.

CONAVI. Boomtown Mexico - A Perspective of the Housing Sector for the Period 20072012. CONAVI:2007.

INFONAVIT. Hacemos realidad el derrecho a vivir mejor. México D.F.: INFONAVIT, 2007

INFONAVIT. Plan Financeiro 2007-2011. México D.F. INFONAVIT, 2007.

PARDO, Marís del Carmem; SÁNCHEZ, Ernesto Velasco (coord.). El processo de modernización en el Infonavit 2001-2006: Estrategia, redes y liderazgo. México D.F.: El Colegio de México, 2006.

SOFTEC. Mexican Housing Overview. México D.F.: SOFTEC, 2005.

VERONEZI, ANA BEATRIZ POLI. Condições para validação de construção de habitação popular no Brasil. 12 p. VII SEMINÁRIOS LARES - Latin American Real Estate Society, 2007. 